\begin{tabular}{|c|c|c|c|c|c|c|}
\hline \multirow{4}{*}{ Impact Factor: } & ISRA (India) & $=3.117$ & SIS (USA) & $=0.912$ & ICV (Poland) & $=6.630$ \\
\hline & ISI (Dubai, UAE & $=0.829$ & РИНЦ (Russia) & $=0.156$ & PIF (India) & $=1.940$ \\
\hline & GIF (Australia) & $=0.564$ & ESJI (KZ) & $=8.716$ & IBI (India) & $=4.260$ \\
\hline & JIF & $=1.500$ & SJIF (Morocco) & $=5.667$ & OAJI (USA) & $=0.350$ \\
\hline
\end{tabular}

\begin{tabular}{|c|c|}
\hline $\begin{array}{l}\text { SOI: } \underline{1.1 / \mathrm{T}} \\
\text { International Sc } \\
\text { Theoretical } \boldsymbol{\&}\end{array}$ & $\begin{array}{l}\text { AS DOI: } 10.15863 / \text { TAS } \\
\text { ientific Journal }\end{array}$ \\
\hline p-ISSN: 2308-4944 (print) & e-ISSN: 2409-0085 (online) \\
\hline Year: 2019 Issue: 02 & Volume: 70 \\
\hline Published: 13.02 .2019 & http://T-Science.org \\
\hline
\end{tabular}

UDC 335. 47 519. 74.

SECTION 31. Economic research, finance, innovation, risk management.
QR - Issue

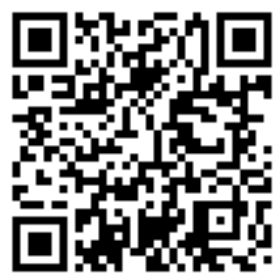

QR - Article

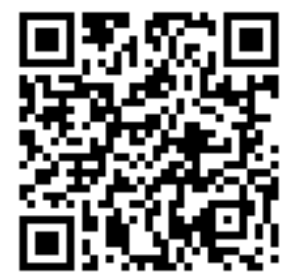

Artur Alexandrovich Blagorodov bachelor, Department of "Design, technology, and design" Institute of service sector and entrepreneurship (branch) of DSTU in Shakhty, Rostov region bordux1995@icloud.com

Dmitry Olegovich Bordukh bachelor, Department of "Design, technology, and design" Institute of service sector and entrepreneurship (branch) of DSTU in Shakhty, Rostov region bordux1995@icloud.com

Angelina Vladimirovna Kopylova bachelor, Department of "Design, technology, and design" Institute of service sector and entrepreneurship (branch) of DSTU in Shakhty, Rostov region prohorov@sssu.ru

Daria Sergeevna Smolina bachelor, Department of "Design, technology, and design" Institute of service sector and entrepreneurship (branch) of DSTU in Shakhty, Rostov region prohorov@sssu.ru

Vladimir Timofeevich Prokhorov Doctor of technical sciences, professor, Professor the department "Designing, technology and design", ISOP (f) DGTU, Shakhty prohorov@sssu.ru

Yuri Dmitrievich Mishin candidate of philosophy, Professor, Department of Philosophy and Culturology "Siberian state University of railway communication" Novosibirsk vinichenkoan@stu.ru

\title{
COMPARATIVE ANALYSIS OF ECONOMIC THEORIES FOR THEIR EFFECTIVE MANAGEMENT TEAM OF THE COMPANY FOR DEFECT-FREE DIGITAL PRODUCTION OF IMPORT-SUBSTITUTING PRODUCTS TO CONSUMERS OF THE SOUTHERN FEDERAL DISTRICT AND SKFO. (2 MESSAGE)
}

Abstract: in the article the authors analyze the possibilities of policy and objectives in the field of quality in the framework of (QMS) for machine-building enterprises on the basis of "JSC LMC" "plant "Techmash"" "LLC" Dontex "and" LLC Metalstroy " that would fight for a defect-free production, making popular and importsubstituting products, to fight for the reduction of marriage and to guarantee consumers high quality products. The use of statistical methods of quality control ( using the Pareto chart tool) to ensure the production of import- 


\begin{tabular}{|c|c|c|c|c|c|c|}
\hline \multirow{4}{*}{ Impact Factor: } & ISRA (India) & $=3.117$ & SIS (USA) & $=0.912$ & ICV (Poland) & $=6.630$ \\
\hline & ISI (Dubai, UAE & $=0.829$ & РИНЦ (Russia & $=0.156$ & PIF (India) & $=1.940$ \\
\hline & GIF (Australia) & $=0.564$ & ESJI (KZ) & $=8.716$ & IBI (India) & $=4.260$ \\
\hline & JIF & $=1.500$ & SJIF (Morocco & $=5.667$ & OAJI (USA) & $=0.350$ \\
\hline
\end{tabular}

substituting products. The use of Pareto diagram allowed the authors to visualize the results of the efforts of the company's managers within the QMS to provide them with faultless and waste-free production with a significant reduction in the output of defective products.

Key words: QMS, certification, import substitution, demanded, conformity assessment, standardization, audit, demand, defective products, Pareto chart, quality policy and objectives, documentation, effectiveness, efficiency, responsibility,

Language: Russian

Citation: Blagorodov, A. A., Bordukh, D. O., Kopylova, A. V., Smolina, D. S., Prokhorov, V. T., \& Mishin, Y. D. (2019). Comparative analysis of economic theories for their effective management team of the company for defect-free digital production of import-substituting products to consumers of the Southern federal district and SKFO. (2 message). ISJ Theoretical \& Applied Science, 02 (70), 101-153.

Soi: http://s-o-i.org/1.1/TAS-02-70-11 Doi: rossef https://dx.doi.org/10.15863/TAS.2019.02.70.11

\section{СРАВНИТЕЛЬНЫЙ АНАЛИЗ ЭКОНОМИЧЕСКИХ ТЕОРИЙ НА ПРЕДМЕТ ИХ ЭФФЕКТИВНОГО УПРАВЛЕНИЯ КОЛЛЕКТИВОМ ПРЕДПРИЯТИЯ ДЛЯ БЕЗДЕФЕКТНОГО ЦИФРОВОГО ПРОИЗВОДСТВА ИМПОРТОЗАМЕЩАЕМОЙ ПРОДУКЦИИ ПОТРЕБИТЕЛЯМ ЮФО И СКФО. (СООБЩЕНИЕ 2)}

Аннотация: в сообщении 2 авторы анализируют возможности политики и цели в области качества в рамках (СМК) для машиностроительных предприятий на базе ОАО «НЛМК»ООО завод «Техмаш»ООО «Дон - Текс» и ООО «Металл-строй», чтобы бороться за бездефектное производства, изготавливая востребованную и импортозамещаемую продукцию, бороться за снижение брака и гарантировать потребителям высокое качество изготавливаемой продукиии. Применение статистических методов контроля качества, ( с использованием инструмента - диаграммы Парето) с целью обеспечения производства импортозамещчаемой продукции. Использование диаграммы Парето позволили авторам наглядно представить результаты усилий руководителей предприятия в рамках СМК обеспечивать им бездефектное и безотходное производство с существенным снижением выпуска бракованной продукции .

Ключевые слова: СМК, сертификация, импортозамещение, востребованное, подтверждение соответствия, стандартизация, аудит, спрос, бракованная продукция, диаграмма Парето, политика и иели качества, документация, результативность, эффективность, ответственность.

\section{Введение}

В начале исследований преимуществ партисипативного подхода к управлению просятся несколько соображений общего порядка. Ни в коем случае не покушаясь на высокие чувства христиан, рискнём предположить, что конкретность бытия Творца люди срисовали с себя самих. Христианский Бог триедин в качестве созидателя, и человек выступает в трёх ипостасях в качестве исторического субъекта. Он - начало своей истории, он - ключевое её средство, и в него заложена цель социального прогресса.

Последнее коробит либеральных экономистов, абсолютизирующих значение прибыли. Для них прибыль от деятельности существует в одном виде - в образе приращения денежных результатов. Гуманитарный и социокультурный эффекты либералы оценивают исключительно как сопутствующие явления, чаще сдерживающие прибыль. В действительности же история прирастает развитием человеческой личности.

Человеческий капитал необходимо квалифицировать как критерий социального прогресса. Показательно не увеличение капитала тех, кто его получил, благодаря специфике существующего способа производства, приспосабливая ее под свои приватные интересы, а совершенствование знаний, чувств, мышления, практических навыков семи миллиардов жителей Земли, которая так и не стала райским уголком жизни, не оправдавших надежд Создателя первых людей и их потомков. Очень хочется надеяться, что это пока. Если Бог есть и он есть такой, каким мы его знаем, то каждый получит своё в своё время, согласно закону бытия.

Ни одна тысяча лет понадобилась человечеству, чтобы понять бесперспективность рабского труда. Без законности своей доли в продукте труда и в зависимости его от сделанного работником, труд остался бы подневольным. В частном порядке уже сейчас немало тех, для кого труд стал потребностью. Они без труда жить не могут. Это увлечённые люди, счастливые тем, что удалось найти себя в труде, выразить себя, получить признание. Материальное вознаграждение необходимо по определению, как условие воспроизводства, но не достаточно для творческого человека. Он заточен на социокультурную оценку своих способностей.

К сожалению, трудоголиков не так уж много и больше не становится. Причина в том 


\begin{tabular}{|c|c|c|c|c|c|c|}
\hline \multirow{4}{*}{ Impact Factor: } & ISRA (India) & $=3.117$ & SIS (USA) & $=0.912$ & ICV (Poland) & $=6.630$ \\
\hline & ISI (Dubai, UAE & $=0.829$ & РИНЦ (Russia) & $=0.156$ & PIF (India) & $=1.940$ \\
\hline & GIF (Australia) & $=0.564$ & ESJI (KZ) & $=8.716$ & IBI (India) & $=4.260$ \\
\hline & JIF & $=1.500$ & SJIF (Morocco) & $=5.667$ & OAJI (USA) & $=0.350$ \\
\hline
\end{tabular}

одна - отчуждение в труде творческого таланта личности. Труд выглядит в современном высокотехнологичном производстве эффектно, внешняя картинка способна даже завораживать наблюдателя, заставить завидовать положению тех, кто занят в светлых, чистых, обустроенных цехах. Однако конвейерная сборка подчиняет своему ритму физиологию, выматывает психику. Появился и формально определился диагноз интенсивного труда: «профессиональное выгорание». Теоретически труд в XXI веке свободен, но свобода труда редко где переходит границу права выбора, отличающегося не существом, а разницей отдельных условий труда. Разумеется, исходя из положения о решающей роли в истории личности, можно спросить: почему недоглядели, кто смел допустить отступление от нормативов? Только всё это мало что изменит.

Объективно с общественным разделением труда сложилось экономическое основание для неравного развития с последующей преференцией для одних заставить работать на себя других. История отчуждения началась именно как экономический процесс. Борьба людей за существование, с утратой первобытной общиной доминантного положения, трансформировалась в конкуренцию, которую пытаются из исторической неизбежности для некоторого этапа социального прогресса представить универсальным инструментом общественного совершенствования на уровне цивилизации.

Частная собственность и конкуренция коррелируются в истории, но причинным механизмом связаны относительно. Конкуренция - явление более общего размера, способное быть и в отсутствии частной собственности. У конкуренции, также как и у эгоизма возможны два «лица»: первое, - задавить соперника, второе, - стимулировать того, кто в общем с тобою строю делает одно дело. И в первобытной общине люди различались физически, духом, следовательно, и вклад их в общее дело был неодинаков, но те, кто был сильнее, служил примером, продвигая деятельность к результату, мобилизуя остальных.

Общинный склад жизни не умер одновременно с первобытной общиной и не трансформировался из практической организации в утопический коммунистический идеал. Общинная организация не только сохранилась, приспособившись к новым обстоятельствам жизни, она была идеологически переосмыслена в качестве той формы труда, которой принадлежит будущее. «Новые люди» Н.Г. Чернышевского были высоко оценены в народническом движении 1870-х годов. П.А. Кропоткин признанный лидер революционеров писал в своих «Записках революционера»: «В нигилистах
Чернышевского...мы уже видели лучшие портреты самих себя» [1]. И пояснял, что подлинный нигилист требует личную свободу, но только для того, чтобы иметь возможность воспользоваться ею для претворения в жизнь социального идеала. Соревнование во имя созидания светлого будущего является формулой истинно разумной конкуренции.

Либеральное толкование конкуренции как закона экономического прогресса упрощает её понимание, подчиняет абстрактной свободе. У конкуренции действительно утилитарная перспектива присутствует и её всячески стимулирует буржуазный общественный порядок. Классический переход к капитализму опирался на примитивные принципы «победитель прав», «победителя не судят». Взять, к примеру, наращивание необходимого начального капитала в Англии или США. Чем, спрашивается, отличались действия первых удачных капиталистов от грабителей и бандитов? Их отличие было только в масштабах. Джентльмены-буржуа действовали с размахом, ведь они прокладывали путь истории нового экономического устройства. Нет ничего удивительного и в том, что удачливые грабители, поумнев, пополнили ряды респектабельных буржуа.

История капитализма время от времени повторяет первоначальные сюжеты. Сколько отечественных бандитов и мошенников из 1990-х и «нулевых» чувствуют себя безнаказанными с паспортами Израиля, Великобритании. К ним нет серьезных претензий у новых хозяев, правда, пока они оплачивают своё очередное гражданство. Сколько такое может тянуться? До тех пор, пока в конкуренции они доказывают своё преимущество, либо есть что инвестировать, жертвовать в пользу спрятавшего их государства. Конкуренция подобного рода - страшная штука, она производит и капиталы, и смерть, но большие капиталы затеняют смертельную опасность.

Проблема буржуазной конкуренции - это её общественно-затратная сущность. Видимая приватно непосредственная сторона такой конкуренции находится в противоречии с ценой, которой общество вынуждено оплачивать, достижения частного характера. Среди нобелевских триумфаторов-экономистов нет тех, кто подсчитал потери социального прогресса от предпринимательской конкуренции. Потери эти естественно распределяются на рынке, отражаясь в ценниках. Налогоплательщики оказываются в стрелочниках. Побеждённых в конкуренции на несколько порядков больше победителей. Их совокупная энергия списывается в издержки, а издержки замаскируют экономической политикой. В данном раскладе форма собственности существенно не участвует. Какая 


\begin{tabular}{|c|c|c|c|c|c|c|}
\hline \multirow{4}{*}{ Impact Factor: } & ISRA (India) & $=3.117$ & SIS (USA) & $=0.912$ & ICV (Poland) & $=6.630$ \\
\hline & ISI (Dubai, UAE & $=0.829$ & РИНЦ (Russia & $=0.156$ & PIF (India) & $=1.940$ \\
\hline & GIF (Australia) & $=0.564$ & ESJI (KZ) & $=8.716$ & IBI (India) & $=4.260$ \\
\hline & JIF & $=1.500$ & SJIF (Morocco & $=5.667$ & OAJI (USA) & $=0.350$ \\
\hline
\end{tabular}

разница кто стал банкротом - частник или государственное предприятие, потери понесёт общество.

Рекламируемая форма конкуренции скрывает истинные экономические возможности общества в интересах капитала, "человеческий капитал» прицепляют к финансовым путеводителям, выставляя на чужой для него путь, загоняя в тупик. Конкуренция как инструмент захвата контроля над экономикой, а через неё и над политикой, расширяется и возносится до государственных и международных масштабов. Её «дубинкой» уже размахивает президент США, стремясь кого-то проверить на лояльность, но, в основном, напугать, задавить, заставить терпеть. Для Д.Трампа конкуренция - испытанный способ достижения выгодного политического порядка в международных отношениях. Во имя этого он готов подрывать инициативы по исправлению экологической ситуации, плодить террор, создавать напряжённость в мире. Он - бизнесмен, капиталист и готов оголить экономические критерии государственной политики, если того потребуют интересы капитала. Конкуренция возведена в механизм создания мирового хаоса в надежде, что в нём сила и подменит правду.

Россию в конце прошлого века втянули в новейший мировой передел. Однако наши демреформаторы просчитались с определением местоположения национального «вагончика» в составе со штатовским локомотивом. Нас поставили в «хвост». Благодаря В.В. Путину, в политике мы шаг за шагом отвоёвываем «раздачу» Горбачева и Ельцина, однако есть ещё и экономика и экономическая политика. Здесь мало что изменилось в сравнении с предшествующими десятилетиями. Декларациями, указами и переходом на «ручное управление» ситуацию не переломить. Поэтому и удивляются современники: вы не довольны либеральной экономической политикой «а ля USA», голосуете на выборах единодушно против, а в практической части экономика по-прежнему подчинена либеральным принципам и правят её либералы. Бюрократия заточена на охрану либеральных ценностей. С каждым новым кризисом богатые становились богаче за счёт бедных. От 0,5 до 1 процента россиян владеет тремя четвёртыми национальных богатств, либо распоряжаются ими, не очень считаясь с национальными интересами, угнетают нашу производственную классику, ссылаясь на нерентабельность, подменяют действительную техническую и экономическую проблематику бутафорскими инновациями, тормозят импортозамещёние там, где нужно помогать активировать отечественный потенциал, внедряют тот чужой опыт, который для нас действительно чужой, вместо того, чтобы возрождать задвинутые находки прошлого национального опыта, показывать как они работают в той же Японии.

Островное положение Японии и высокая плотность населения обуславливают специфическое восприятие в этой стране экономической реальности. Японский капитализм мало похож на европейский и североамериканский. В Европе и особенно в США капитализм разложил и противопоставил национальные общности. Отсюда и знаменитые революции и войны в Британии, Франции, Германии, Италии, Испании. Конкуренция сотворила свой закономерный результат даже в истории духовности, разделив католическую единую веру и породив религиозные войны. Общинный дух пытались реанимировать в Европе социалисты-утописты (Р. Оуэн). Успеха не имели, повторяли свои эксперименты на Севере Америки также безуспешно. Конкуренция умертвила силу общинного духа на генетическом уровне. А в Японии дух семьи нарастили единым духом компании. Компания - семья семей, большая общая семья с семейными традициями и соучастием власти. Помогла и специфика религии. Один из активных пропагандистов TQM - его японского прочтения, К. Мацусита объяснял западным менеджерам: «Для вас суть руководства в том, как взять идеи из голов менеджеров и вложить их в головы персонала, отвечающего за выполнение технологических операций. Для нас - по крупице собрать интеллектуальные ресурсы всех работников и поставить их на службу предприятия. Мы оценили экономические и технологические возможности и знаем, что интеллектуального потенциала группы самых способных и блестяще подготовленных менеджеров недостаточно для достижения успеха». Именно японцы вновь, после советского опыта, открыли тот факт, что не только наука становится всё больше непосредственной производительной силой, но и культура, особенно культурный национальный менталитет. Японцы конкурируют в производстве за право быть больше японцем, чем по паспорту. Для них работа на фирме, как правило, семейное участие. Фирма - второй дом, который определяется национальным порядком. Они служат малой родине, чтобы процветала большая. Наши же идеологи бездарно ищут малое лицо большой родины, а так как подавляющее большинство «малых родин» очень далеки от удовлетворительного состояния, то и образ большой родины выглядит красиво на буклетах и по телевизору. Пора от абстрактного патриотизма переходить к реальному. Политика должна заняться преодолением нарастающего 


\begin{tabular}{|c|c|c|c|c|c|c|}
\hline \multirow{4}{*}{ Impact Factor: } & ISRA (India) & $=3.117$ & SIS (USA) & $=0.912$ & ICV (Poland) & $=6.630$ \\
\hline & ISI (Dubai, UAE & $=0.829$ & РИНЦ (Russia) & $=0.156$ & PIF (India) & $=1.940$ \\
\hline & GIF (Australia) & $=0.564$ & ESJI (KZ) & $=8.716$ & IBI (India) & $=4.260$ \\
\hline & JIF & $=1.500$ & SJIF (Morocco) & $=5.667$ & OAJI (USA) & $=0.350$ \\
\hline
\end{tabular}

отчуждения личности в труде. Надо заинтересовать трудом материально и морально.

Абсолютизация конкуренции в её персонифицированном проявлении либеральной концепцией экономического прогресса напоминает время господства патристики в эпоху Средневековья, когда Бога «боготворили», убеждённые в том, что его всеобщность надо понимать дословно, теистически. Бог - не столько творец, сколько менеджер сотворённого мира. В последующем теологи сообразили, что такое представление Бога не возносит, а подрывает его суть - «творящий момент». В итоге разобрались, допустили истинность нерелигиозного познания, признали действенность философии, науки, искусства, получив при этом прибыль,- на Бога стала работать вся «культурная рать». Опасность абсолютизации давно известна, но, когда надо что-то «продавить», то рискуют. Тем более, что риск минимизирован - затраты спишут как издержки, их почувствуют потребители.

Популяризация буржуазного, ставшего экономической классикой, толкования конкуренции, с одной стороны, разумна, ибо концентрированно выражает специфику буржуазного способа производства, опирающегося на свободу индивидуальности бытия человека. С другой, в ней столь же агрессивно выражается стремление абсолютизировать индивидуальность человеческого бытия как идеал демократии. Буржуазные революционеры были убеждены, что феодальное общество исторически умерло, исчерпав свои социокультурные, политические и экономические резервы. Они лишь «толкнули» его, чтобы упал и не мешал прогрессу. Когда же буржуазные революционеры обрели господство, сменив статус оппозиционеров на власть, то решили отказаться от принципа историзма в истории общественного развития. Буржуазное философское осмысление социального прогресса не было бы буржуазным, если бы не конкретизировало политическое мышление опорного класса. Политическое мышление буржуазии и нашло свой максимум в абсолютизации персонифицированной конкуренции. Робинзон Крузо Даниэля Дефо уперся в жизненный тупик, потому что у него не было конкурентов. Пятница - не в счёт, он варвар и слуга. Удел всех граждан в условиях буржуазной демократии бороться за своё «я» со всеми другими «я», противостоящими его «я» и образующими совокупность «не я». Только отношения «я» и «не я» способны быть реальной силой, подобно паре «сила-реакция» в механике. Государство - диспетчер и главный цензор такого противоречия.
Точкой отсчета этой концепции является индивидуальность бытия, противопоставленного социальной форме бытия. Последнее рассматривается также механистически как сумма форм индивидуального бытия образующего его множества. Интересы общества растворяются в потребностях индивидуала. В практическом аспекте данная теория выражается в различиях социально-экономического статуса граждан, которую объясняют также конкуренцией. Чтобы 10 процентов богатых не вызывали негодование 10 процентов бедных, их разделили «средним классом», определи его в качестве социального буфера. Целью развития сделалось расширение среднего класса.

Основоположники

классической политической экономии, отправляясь от трудовой теории стоимости, нащупали коренные проблемы буржуазного производства, обозначили проблемы разрешения противоречий, но дальше продвинуться не сумели. Их мысль сковали демократическая наивность и подчинение анализа формально-логическому подходу к мышлению. Даже А. Смитт терялся в объяснении нелогичности развития отношений между ростом производительности труда и размером вознаграждения работников, наивно убеждённый, что так не должно быть. Экономическая теория только во второй половине XIX века «впустила» диалектику анализа капитала, а вместе с ней начал формироваться и новый взгляд на противоречивость процесса. Основной механизм движения производства действует не в системе формально-логического непротиворечия и не определяется в системе «плюс или минус», а обусловлен двойственностью оценки результата, что исключает абсолютизацию любого действия. Конкуренция - это противоречивый фактор, поэтому управлять конкуренцией необходимо в рамках её диалектической природы и противоречивости эффекта действия.

\section{Основная часть}

Допустимо ли в рамках научного анализа сравнение реального объекта с явлением из фольклорной классики, к примеру, рынка со сказочной пещерой Аладдина? Ответить на этот вопрос нелегко, так как мышление достаточно специализированно, а специализация закрепляется в определённых традициях, формализующих подход. Научное редактирование требует соблюдения требований характерного для науки способа изложения содержания мыслей. Неопозитивисты вообще пытались построить специальный язык научных коммуникаций, правда, безуспешно. Коллизия разрешалась практически, самими учеными, большинство из которых активно вовлекали в научные публикации образное мышление, 


\begin{tabular}{|c|c|c|c|c|c|c|}
\hline \multirow{4}{*}{ Impact Factor: } & ISRA (India) & $=3.117$ & SIS (USA) & $=0.912$ & ICV (Poland) & $=6.630$ \\
\hline & ISI (Dubai, UAE & $=0.829$ & РИНЦ (Russia) & $=0.156$ & PIF (India) & $=1.940$ \\
\hline & GIF (Australia) & $=0.564$ & ESJI (KZ) & $=8.716$ & IBI (India) & $=4.260$ \\
\hline & JIF & $=1.500$ & SJIF (Morocco) & $=5.667$ & OAJI (USA) & $=0.350$ \\
\hline
\end{tabular}

справедливо полагая, что мышление представляет собой единый поток движения понятий и образов, логического и внелогического, реального и фантастического, воображаемого. Познание в любом выражении процесс поступательный, соединяет непрерывное с дискретным, обычное с необычным. Нормализованное мышление относительно, условно, организованно искусственно. Обращение в научном мышлении, включая его печатные формы, к образам, созданным вне научной специализации познания, естественно, обусловлено технологически.

Мышление не может существовать вне культуры, оно продукт культурного прогресса. Разнонаправленное развитие культуры - основа ее богатства, а противоречия культурного мышления диалектически едины. Сравнивая богатства сказочной пещеры с богатством развитого современного рынка, можно многое прояснить, как в экономическом познании, так и динамике трансформации экономической теории, в частности объяснить, почему современные ученые экономисты упорно дистанцируются от политического характера экономической науки, противопоставляя экономическую теорию классической политэкономии.

Воля, упорство, находчивость обеспечили Аладдину доступ к пещерным богатствам. Никакие хитросплетения не способны остановить целеустремленного человека. Нет непознаваемого, есть еще непознанное. Рынок сложный экономический механизм, но и его можно понять и взять в управление. Богатства пещеры принадлежали насильникам, рынок также не свободен от насилия, поэтому государство обязано предпринимать необходимые меры обуздания рыночной стихии, служащей благодатной почвой для тех, кто предпочитает силу закону. Коренное же отличие богатств пещеры и рынка в том, что разбойники ничего больше не собирались добавлять, и Аладдин должен был довольствоваться полученным. Богатства же рынка, напротив, будут расти и вместе с ними проблемы, главная из которых реализация товарных поступлений. Каким должен быть товар, чтобы покупатель сметал его с полок? Какого покупателя хотели бы видеть на рынке?

Если «покупателя» рассматривать вне социально-экономического контекста, то ответ на второй вопрос выглядит предельно ясным. Рынок ждет покупателя с высокой платежеспособностью. Такие покупатели в России есть, однако их доля не превышает 7 процентов, и на привычный для масс рынок они редко ходят, скорее случайно, чем по необходимости. Массовый потребитель предельно экономен и «раскачать» его на покупку тяжело. Здесь требуется определённый вид товара, способный очаровать, и подача товара, - «культурная упакованность». Надо привлечь покупателя, заворожить. Как отражение стремления осмыслить специфику статуса востребованности товара на рынке нужно рассматривать оживление интереса к понятию «привлекательность товара». Оно существенно конкретнее по содержанию в сравнении с близким и более наукообразным понятием «востребованность товара рынком». В нем меньше экономической статистичности, формальных признаков, позволяющих измерять давление, но в полном объеме присутствует «человеческий фактор», определяющий рыночную динамику.

Понятие «привлекательность товара» конкретизирует в характеристике товара одновременно его потребительскую стоимость степень «обменности» на деньги и реалистичность цены, установленной продавцом. С понятием «привлекательность», обращенным векторно в сторону покупателя, приходится дружить и производителю, и продавцу. Оно связывает узлом интересы всех основных субъектов экономически свободного рынка. Данная функция «привлекательности» объясняет активное продвижение понятия в группу тех экономических категорий, которые раскрывают потенциал конкурентоспособности продукта на рынке. Это выдвижение отдельные авторы склонны трактовать как традиционные действия в интересах приложения рекламного производства, что делать нецелесообразно по причине односторонности, мешающей достижению системного понимания значения привлекательности товара в процессе воспроизводства. Рекламное производство действительно здесь присутствует, но в качестве сопровождающего фактора, то есть подтверждается обычное место рекламы на рынке.

Возрастающий интерес в научных исследованиях и экономической политике к понятию «привлекательность товара», на наш взгляд, показывает закономерность перестройки массового производства с существующего упрощенного типа к новому, иногда противопоставляемого ему, способу организации - lean production (рачительному, щадящему производству), ориентированному не на абстрактное многообразие потребностей покупателей, а на конкретную архитектонику потребительских запросов и платежеспособности потенциальных покупателей. Экономическую науку призывают через изучение архитектуры рынка сделаться непосредственной производительной силой, объективировать таким 


\begin{tabular}{|c|c|c|c|c|c|c|}
\hline \multirow{4}{*}{ Impact Factor: } & ISRA (India) & $=3.117$ & SIS (USA) & $=0.912$ & ICV (Poland) & $=6.630$ \\
\hline & ISI (Dubai, UAE & $=0.829$ & РИНЦ (Russia) & $=0.156$ & PIF (India) & $=1.940$ \\
\hline & GIF (Australia) & $=0.564$ & ESJI (KZ) & $=8.716$ & IBI (India) & $=4.260$ \\
\hline & JIF & $=1.500$ & SJIF (Morocco) & $=5.667$ & OAJI (USA) & $=0.350$ \\
\hline
\end{tabular}

образом, основное последствие научнотехнической революции середины ХХстолетия.

История выделения рынка товаров в зону особого внимания экономистов и социологов сопряжена с рождением и развитием массового производства. Время массового фабричнозаводского производства исчисляют с Промышленной революцией, заложившей научно-технические и организационные предпосылки такого развития производительности труда, которое оказалось достаточным для реальной возможности удовлетворить спрос на жизненно значимые товары основной части населения посредством предоставления работы и устойчивой платы за труд. Именно это сочетание производства и потребления запустило развитие воспроизводства в национальных, а затем и транснациональных масштабах.

Предшествовавшее промышленному этапу натуральное хозяйство не соответствует в полной мере понятию «воспроизводство», оно определялось локальной востребованностью производимого продукта и было по существу замкнуто на производителя, не способствуя в должной степени национальному прогрессу. Отсюда и культ захватнических войн, нацеленных на грабеж ближних и дальних соседей, феодальная раздробленность, постоянный передел собственности. Войны и силовые акции выполняли функции рынка. Рынок работал в дополнение к политике, не был перманентным.

Уместно также подчеркнуть, что развитие рынка и формирование ставшего классическим образа воспроизводства, обязаны не только научно-техническому прогрессу, смене способа организации производства, но и конкуренции продуктов производства на рынке, дифференциации рыночной структуры. В истории рынка виден диалектический закон взаимосвязи количественных и качественных изменений. Когда производитель стал работать на рынок, продукт превратился в товар. Изменился статус продукта, поменялись и требования, предъявляемые к нему. Чтобы продукт был реализован по предназначению, он должен был привлечь к себе внимание покупателя. Товар это не продукт на продажу, а продукт, способный заинтересовать. Термин «ходовой товар» отражает как раз движение товара, его востребованность покупателем. «Ходовые товары» - локомотивы рынка.

Признак «привлекательности» принадлежит и к базовым характеристикам товара, и является «реликтовым» его свойством, укрепившим свои позиции. Непривлекательный товар производить непрофессионально, абсурдно. Домашних можно было заставить, приучить потреблять то, что заготовили, вырастили или изготовили, покупатели же имеют всегда свой резон и голосуют монетой, столь необходимой для продолжения производства.

В новейшее время синонимом «привлекательности» используется понятие «товарный вид». Отсюда, возможно, пошло выражение «видный товар», то есть тот, что аккумулирует к себе внимание, «бросается» в глаза. Умение сделать товар «видным», «привлекательным» требует и от производителя, и от продавца высокой квалификации, профессиональной фантазии, навыков презентации. Дело это затратное, но расходы окупаются результатом. Спрос на «привлекательный», «видный» товар высок, ускоряет получение оборотного капитала, стимулирует наращивание производства, консолидирует отношения продавца с производителем, придает прирастанию производства устойчивость, что служит хорошей рекламой производителю на рынке, избавляет от части прямых уплат рекламных услуг, обходящихся все дороже из-за своей вычурности.

Даже панорамно-историческое обозрение системного положения понятия «привлекательность» свидетельствует о его многогранности и сложности проявления. Тот факт, что термин «привлекательность» не столь часто встречается в журнальных публикациях, не должен вводить сознание в состояние вопроса относительно действительной значимости данного признака товарности в происходящей экономической перестройке на уровень lean production. Не случайно, отвечая на вопрос «Левада-центра», заданный в апреле 2017 года: «Что прежде всего внушает вам чувство гордости за Россию?», 1600 граждан страны из 137 населенных пунктов 48 регионов РФ «экономические успехи» поставили на предпоследнее место, отдав последнее «родственнице» - «системе здравоохранения». [1 (АиФ №20, 2017)]

К. Маркс начинал исследование буржуазного способа производства с анализа противоречивой природы товара. Товар объективно характеризуется наличием потребительской и меновой стоимости. Первая определяет его востребованность на рынке, вторая - меру такой востребованности. Стоимость объективирует трудовые затраты количество и качество произведенного труда. Труд также проявляется через противоречие, рожденное товарной сущностью капиталистического воспроизводства. С одной стороны, он есть созидательная, творящая сила человека, - грань его сущности, с другой, он с необходимостью отчуждает эту человеческую сущность, ибо продукт труда, вобравший в себя 


\begin{tabular}{|c|c|c|c|c|c|c|}
\hline \multirow{4}{*}{ Impact Factor: } & ISRA (India) & $=3.117$ & SIS (USA) & $=0.912$ & ICV (Poland) & $=6.630$ \\
\hline & ISI (Dubai, UAE & $=0.829$ & РИНЦ (Russia) & $=0.156$ & PIF (India) & $=1.940$ \\
\hline & GIF (Australia) & $=0.564$ & ESJI (KZ) & $=8.716$ & IBI (India) & $=4.260$ \\
\hline & JIF & $=1.500$ & SJIF (Morocco) & $=5.667$ & OAJI (USA) & $=0.350$ \\
\hline
\end{tabular}

созидательную силу, производится для чужого потребления. Марксизм выводит из теории отчуждения социальный тупик развития буржуазного общества. В своем главном труде К. Маркс разрабатывал не только теорию развития капитализма, ему важно было довести до рабочего вида диалектико-материалистический метод научного анализа. Диалектика Г. Гегеля была локальной. Гегель ограничил диалектическое развитие движением духа. Маркс видел в диалектике универсальный способ развития, поэтому в «Капитале» обстоятельно проследил диалектику производства, сделав акцент на материальность природы товара, создаваемого трудом. Качество товара создается противоречивой природой товара и проявляется через отношение его в форме существенных признаков. Диалектический материализм опирается на признание материальности товара. Нематериальные товары - своего рода товарный полуфабрикат, «переходная форма» к практическому выражению, материализации. Однако материальность товара специфична.

Качество природных явлений действительно тождественно их материальной природе, но товар, даже в своей конечной формематериальности, есть нечто отличное от созданного вне и независимо от существования человека. Труд в товаре материализует разумную сущность человека - чувства, мысли, идеалы. В товаре выражается разумность человеческой реальности, следовательно в понятии «качество товара» должна быть запечатлена духовность человека, подтверждающая, что товар создается человеком для человека. На наш взгляд, рыночное качество товара призвано раскрывать единство стоимостей посредством сочетания естественной природы материала и искусственного ее преобразования творческой деятельностью человека. Качество товара, наряду с функциональностью, определяется его привлекательностью.

Привлекательность - высоко значимый фактор ценообразования. Часть цены, зависимая от привлекательности, может рассматриваться как экономический эквивалент привлекательности. Измеряется эта часть размером востребованности. Получение товара с новыми функциями затратно и ограниченно физической природой. Этот путь удивить потребителя сопряжен с риском снижения конкурентоспособности из-за высокой себестоимости. Проще и перспективнее манипулировать сознанием. Для этого есть готовые психологические механизмы и необходимые научные знания. Если товар в своем виде не произвел должного впечатления, не привлек, его можно сделать привлекательным, модулируя в определенном контексте, например, действуя на психику субкультурного восприятия. Сколько у нас эстрадных «звезд» без должных голоса и вокальной культуры. Мало того, что они привлекают своим исполнительским «мастерством», с них пытаются копировать одежду, аксессуары, обувь. Они формируют вкус определенных социальных групп, косвенно влияя на рыночное положение товаров. Нет данных поступить в государственные училища и вузы искусств, иди на «фабрики звезд».

«Привлекательность» обладает такими резервами, о которых у менеджеров еще весьма непрофессиональное представление. Нет сомнений, что в будущем маркетологи выйдут за пределы ныне определенного образованием спектра знаний и потеснят управляющих производством, ассортиментом. Управление рынком востребует не так, как ныне, учение 3. Фрейда об «оно», «эго» и условиях достижения «суперэго»; теорию «коллективного бессознательного» К. Юнга; идеи Э. Фромма о значении для сознания способности удивляться и роли в реальной жизни сновидений.

Перспективы рынка и производства связаны c той активностью, которую управляющие проявят в отношении к понятию «привлекательность товара». Самым трудным для них окажется процесс перестройки мышления с утилитарного, прагматичного склада, сформированного парадигмой минимизации расходов для получения итоговой маржи, на новый принцип: получить законно и морально максимальную маржу. Всё энергичнее уходя в математическую методологию, экономисты утрачивают специфику политэкономического анализа, требующего действовать на фоне перспективы. Чаще нужно возвращаться к работам классиков - У. Петти, А. Смита, Д. Рикардо. «Классики» разбираясь в настоящем, думали о будущем, правильно полагая, что наука, ограниченная текущим ходом событий напоминает стоящий на якоре корабль, построенный как средство движения.. «Отцы» экономической науки были философами, их наследники скатились в бухгалтерский учет.

Экономистов можно понять. В условиях нестабильности мирового развития смотреть вперед дальше ближайшего угла крайне опасно. Кризис 2008 года, последствия которого до сих пор заставляют штормить мировую экономику, дело рукотворное. Путь прокладывали нобелевские лауреаты, хотели как лучше. Вышло, как всегда. Экономической науке пора вернуть мышлению масштабы - не только пространственные, но и временные. Исследования настоящего, проводить с заделом на разумно обозримую перспективу, комплексируя их со смежными науками, включая учение В.И. Вернадского о ноосфере. Э. Деминг 


\begin{tabular}{llllll} 
& ISRA (India) $=3.117$ & SIS (USA) $=\mathbf{0 . 9 1 2}$ & ICV (Poland) & $=\mathbf{6 . 6 3 0}$ \\
Impact Factor: & ISI (Dubai, UAE) $=\mathbf{0 . 8 2 9}$ & PUHЦ (Russia) $=\mathbf{0 . 1 5 6}$ & PIF (India) & $=\mathbf{1 . 9 4 0}$ \\
& GIF (Australia) $=\mathbf{0 . 5 6 4}$ & ESJI (KZ) $=\mathbf{8 . 7 1 6}$ & IBI (India) & $=\mathbf{4 . 2 6 0}$ \\
& JIF & $=\mathbf{1 . 5 0 0}$ & SJIF (Morocco) $=\mathbf{5 . 6 6 7}$ & OAJI (USA) & $\mathbf{0 . 3 5 0}$ \\
\hline
\end{tabular}

еще в 1950-е годы, разрабатывая философские основания качества менеджмента, в разделе «Семь смертельных болезней» на первое место поставил планирование, не ориентированное на производство таких товаров и услуг, которые требуют рынок, при этом американский специалист сознавал сложность ситуации. [2]

Отсутствие достаточной для управления разработанности понятия «привлекательность товара» заставляет вспомнить его филологические корни, толкование «привлекательности» в классических источниках. В.И. Даль «привлекать» отождествлял с «притянуть», подчеркивал физический смысл термина, отодвигая на второй план физиологическую и психологическую стороны притягательности - «притягивать нравственно, чувством, силою убеждения..., манить, влечь, увлекать». [3, с.403] Ф. Брокгауз и И. Ефрон не включили в свое собрание этот термин. Обошла его и Britannica, что трудно оправдать, принимая во внимание стремление издания вносить в текст происходящие в мире изменения.

Обстоятельный анализ содержания понятия можно найти в четырехтомном Академическом Словаре русского языка. «Привлекательный, заманчивый, интересный.. который располагает к себе, возбуждает, пробуждает любознательность» [4, c.542]. Продолжая рассуждение о привлекательности, мы выйдем на признак «оригинальности». Обычно именно с оригинальностью, еe конкретностью, возбуждающей интерес к явлению, связывают привлекательность товара, что в общем соответствует представлениям. Вместе с тем, надо стараться не абсолютизировать положение «привлекательности» на товарном рынке.

Судьба товара на рынке определяется его востребованностью. «Востребованность» понятие социально-гуманитарного уровня. Оно обусловлено, с одной стороны, степенью развитости общества и платежеспособности массового потребителя, с другой - структурой потребностей покупателя. Эпикур дифференцировал потребности на основе двух признаков - естественности и необходимости. Согласно представлению античного мыслителя, потребности разделяются на три вида: «естественные и необходимые», «естественные и не необходимые» и «неестественные и не необходимые». [5, с.403, 469]

В суждениях Эпикура имеется подсказка к пониманию статуса товара. Есть товары объективно необходимые, их необходимость рождена естественной в них потребностью. Покупатель обязан такие товары купить - они необходимое условие его выживаемости. Конечно желательно, чтобы товары, составляющие «корзину существования» потребителя, были не только полезно необходимые, но и приятные по ощущениям, однако не приобрести подобные товары разрешается только в двух случаях, когда нечем заплатить и не на что поменять.

Естественно-необходимые товары «ходовые» на рынке всегда. Если они задерживаются на складах, либо в местах реализации, то причина одна - ценовая недоступность, жадность спекулянтов, оккупировавших рынок. Обувь - типичный представитель группы естественно-необходимых товаров, наравне с одеждой и бытовой утварью. Главная функция обуви заключена в ее способности защитить нижние конечности от механических и температурных повреждений. Дизайн обуви регламентирует прежде всего ее функциональной принадлежностью. Эстетическая сторона дизайна надстраивается над базисной функцией. Характерной особенностью обувных залов современных магазинов являются различного рода акции, направленные якобы на снижение цены. Когда третью пару обещают вручить бесплатно в торговом учреждении, это означает, что цена первой и второй позволяет безболезненно компенсировать потери, связанные с «подарком». Они оплачивают своей ценой «подарок». Более очевидного аргумента в пользу определения ситуации с ценообразованием как односторонней не существует. Нефтяники и газовики закладывают в ценообразование расходы на изыскания в сложных, нередко экстремальных обстоятельствах, требующих создания специального оборудования, специфических материалов. Неизведанное и неосвоенное сопряжено с высокими рисками, непрогнозируемыми научно-техническими потерями. Все понимают, что здесь присутствует спекулятивный подход, априорно завышающий потери на производство продукта, но отсутствие безупречно разработанных методик расчета неизбежных инвестиций в проектирование; уровень научно-технического обеспечения, необходимость рискованных действий, существенно смягчают критическую реакцию.

«На войне как на войне» назвал писательфронтовик, горевший в самоходке, свою известную повесть, экстраполируя его подход, повторим вслед: «На рынке как на рынке». Отпустив на свободу рыночные отношения между производителем товара, потребителемпокупателем и продавцом-посредником, власть облегчила жизнь себе и, не исключено, сделала ее безбедной за счет производителя и потребителя. Ценообразование в рыночном хозяйстве объективно предполагает участие таких факторов, как себестоимость товара, потребительская заинтересованность в нем 


\begin{tabular}{|c|c|c|c|c|c|c|}
\hline \multirow{4}{*}{ Impact Factor: } & ISRA (India) & $=3.117$ & SIS (USA) & $=0.912$ & ICV (Poland) & $=6.630$ \\
\hline & ISI (Dubai, UAE & $=0.829$ & РИНЦ (Russia) & $=0.156$ & PIF (India) & $=1.940$ \\
\hline & GIF (Australia) & $=0.564$ & ESJI (KZ) & $=8.716$ & IBI (India) & $=4.260$ \\
\hline & JIF & $=1.500$ & SJIF (Morocco) & $=5.667$ & OAJI (USA) & $=0.350$ \\
\hline
\end{tabular}

покупателя, платежеспособность спроса и оплата участия продавца. Но речь идет о пропорциональном соучастии. Силу рыночных факторов нельзя рассчитать по формулам, описывающим силы в механическом движении, параллелограмма сил здесь не получить, однако пропорциональность соучастия в образовании итоговой цены получить можно с заданной степенью точности. И давно пора было эту операцию провести, чтобы политически и экономически определиться, где проходит граница цивилизованного рынка и базара, выстроенного «по понятиям».

За какую и чью рыночную свободу борются либералы - политики, почему перекосы в рыночном ценообразовании трактуются как естественные издержки развития, нормальные для демократического управления? Почему не совмещают пустые полки магазинов советского времени с очередями? Чтобы не было контраста с забитыми стеллажами нынешних магазинов и отсутствием покупателей? Дефицит действительно был до 1990-х годов, но связан он был в первую очередь с высоким уровнем покупательской способности, ценовой доступностью большинства товаров. Спрос опережал производство. Сейчас, напротив, предложения продавцов явно превосходят реальные возможности покупателей, что бьет больно и по отечественным производителям, так как торгуют привозимыми дешевыми товарами, опасными для здоровья.

Как следствие очередной политикоэкономической диспропорции процветает кредитование, создающее иллюзию покупательской способности. Российского потребителя экономической политикой загоняют в финансовую ловушку. Суть ситуации не в экономической безграмотности населения, а в мировоззренческом примитивизме, насаждаемом повсеместно и агрессивно. Школьников учат запоминать, студентов не учат научно мыслить, называя это модернизацией образования. Жизнь есть способность эффективно действовать, исходя из реальных возможностей. Подмена реальности действительно существующей, заработанной, на виртуально-предметную, жизнь взаймы, неизбежно ведет к духовному нигилизму, моральному разложению и кризису личности.

Первичные причины потребительской одномерности личности надо искать в анархии не выстроенного цивилизованно товарного рынка. Что дальше? Ответ надо искать там же, то есть там, где все с необходимостью встречаются - на рынке. Экономические приоритеты политики призваны определить роль рынка: сделается он братским захоронением родных производителей или пусковым механизмом подъема отечественного производства? Но и производители не должны созерцать происходящее, критиковать политиков и требовать для себя благоприятных условий развития. Они своим статусом в обществе поставлены перед жизненной необходимостью искать новые факторы продвижения, думать о резервах, еще не вовлеченных в процесс.

В замысле О. Конта о том, что каждая наука обязана быть философией, далеко не все ложно. Философы, придерживающиеся классических представлений о философии, спорили с Контом, считая ошибочным отдавать методологию и, особенно, мировоззрение на откуп частнонаучной рефлексии. Растворение философских размышлений в научном познании заведёт последнее в гносеологический тупик, так как спровоцирует абсолютизацию в решении универсальных проблем научного познания. Принятие обобщающих и направляющих решений в познании - удел независимого от специфики приватных суждений «судьи». В то же время, О. Конт был бесспорно прав, полагая, что только незасоренное стереотипами мышление способно действовать продуктивно, быть новаторским, инновационным, креативным. Тот, кто выдвинулся на путь организации развития бизнеса, как молитву №1 «Отче наш», обязан знать и повторять: только диалектическое мышление поможет мне быть успешным, спасет предприятие. Вот только кто в наши годы научит мыслить диалектически? Российские демократы, рулившие в политике конца ХХстолетия, диалектику отождествляли с директивами и лозунгами советской эпохи и сознательно отрубали ей демократические корни также энергично, как выкорчевывали массандровские виноградники подручные М.С. Горбачева, а еще раньше поднимали целину строители коммунизма там, где это не следовало делать, по волюнтаристским указаниям Н.С. Хрущева.

Инициативный

предприниматель обусловлен в принятии решений состоянием и тенденциями существующего рынка. Но диалектически организованное мышление не позволит ему при разработке бизнес-плана, рассчитанного на обозримую перспективу, оказаться в тисках рыночной конъюнктуры. Каким бы произвольно образованным, анархически свободным рынок не был, он регулируется движением производства. Все в производстве связано общим узлом. «Все есть одно», утверждали античные диалектики, и искали то, что делает все единым. Рынок сегодня требует одно, завтра конъюнктура на нем будет другая, правда, нельзя исключить и повторения сегодняшнего. Поэтому нужен предварительный, комплексный, лучше системный, подход. Системный лучше, потому что позволяет 


\begin{tabular}{|c|c|c|c|c|c|c|}
\hline \multirow{4}{*}{ Impact Factor: } & ISRA (India) & $=3.117$ & SIS (USA) & $=0.912$ & ICV (Poland) & $=6.630$ \\
\hline & ISI (Dubai, UAE & $=0.829$ & РИНЦ (Russia) & $=0.156$ & PIF (India) & $=1.940$ \\
\hline & GIF (Australia) & $=0.564$ & ESJI (KZ) & $=8.716$ & IBI (India) & $=4.260$ \\
\hline & JIF & $=1.500$ & SJIF (Morocco) & $=5.667$ & OAJI (USA) & $=0.350$ \\
\hline
\end{tabular}

приобщиться к сущности происходящего, предполагает выделение системообразующего фактора. Системообразующим фактором экономического анализа рыночного производства был и будет товар. Не случайно К. Маркс в «Капитале» начинал с товара, называл его клеточкой экономического организма капитализма и выстраивал из противоречивой природы товара противоречия движения буржуазного способа производства.

На рынке конкурируют не столько сами товары, сколько умы и воля производителей, разумеется оснащенных капиталами. Товары видимая сторона рынка, объективирующая в конкретных физических формах и действиях силу предпринимательского духа. Здесь мы вынуждены вновь обратиться к диалектике, ее требованию искать источник развития в противоречиях и не удивляться превращениям противоположностей, духа - в материальное, материальное - в духовное. Фундаментальный и универсальный вывод диалектики о конкретности истины разъясняет: то, что истинно сейчас, сделается заблуждением потом. Когда? Закономерно возникает вопрос. Ответ надо искать в тенденциях движения. Начинать же обязательно со всестороннего исследования того, из чего все. Для нас - это товар, его необходимые и дополнительные (надстроечные) признаки.

Производство товара обусловлено рынком. Когда-то рынок формировался за счет избыточного продукта и проявлялся в форме ярмарок. Сейчас товар изготавливают под потребности рынка. Рынок же, в свою очередь, аккумулирует в реальном выражении покупательские потребности. Случайно на рынке появляются антикварные продукты или что-то очень необычно новое. Теоретически, беря в расчет разумность человеческой деятельности, ее рациональность, взаимный интерес изготовителя, продавца и покупателя, можно допустить вывод, согласно которому все товары найдут своего потребителя. Если на рынке будут накапливаться нереализованные товары, он потеряет свою функцию и умрет как рынок - место купли и продажи. Практически так оно иногда и происходит. Только рынок не есть нечто абстрактное, существующее вне времени. Он представляет форму конкретно-временной реальности. На рынке особенно важен фактор времени.

Рынок - важнейшее звено, обеспечивающее своевременное воспроизводство товаров. Рыночные акции рождаются не из фантазии. Продавцы согласны нести определенные издержки, секвестировать в свои ожидания именно по причине необходимости сделать все вовремя. Иначе потери увеличатся, к финансовым издержкам присоединятся статусные. В зоне риска окажется авторитет самих субъектов рынка. В контексте данных рассуждений созревает мысль, что главная функция рынка не заставить вообще купить, а заставить купить как можно быстрее. Цивилизованно организованный рынок призван не только своевременно реализовать товар, но и быть фактором ускорения развития производства товаров. Как конкретно это можно осуществить?

Парадокс рынка состоит в том, что будущее рынка безоблачно, все проблемы рынка всегда современные, современными они останутся по мере разрешения одних и нарастания других. Откуда такая уверенность? Из анализа объективно реальных оснований истории рынка. Базисный рыночный товар тот, который обеспечивает естественно-необходимые потребности человека. Вне рынка удовлетворить то, без чего невозможно общественноиндивидуальное воспроизводство, нельзя. Рынок - общественно необходимое условие человеческой жизни и ее прогресса. Рынок должен не только быть, ему исторически вменяется быть фактором развития общества. Соответственно этому предназначению рынку положено быть в качестве развивающейся реальности, а обществу заботиться о развитии рынка. Не свободу давать «сколько способен заглотить» (Б.Н. Ельцин), а управлять свободой рынка в интересах рынка и его системного положения в общественном развитии.

Вернемся к видовой структуре товарного рынка и продолжим его анализ, отправляясь от исходной идеи о «базисном товаре». Удовлетворение с его помощью основных потребностей человека требует расшифровки с привлечением мировоззренческих достижений. Сделать можно и по-другому, упрощенно, только упрощение приведет к предупреждению «здравого смысла»: «простота хуже воровства». В экономическом анализе опасно что-либо недооценивать или переоценивать. Реальность человека дуалистична, вбирает в себя биологическое и социальное. В первом приближении разделить биологическое и социальное в человеке несложно.

Биологическое

удовлетворение потребностей организма в питании, поддержании водно-солевого баланса и обмена, нормальности газообмена, защита температурных условий жизнедеятельности, воспроизводство потомства, перемещение в пространстве посредством самодвижения.

Социальное - удовлетворение условиями трудовой деятельности, развития мышления, сознания, речи, культурным прогрессом.

Биологическое и социальное сочетаются на основе потребности в общении и реализуются в общении посредством деятельности. 


\begin{tabular}{|c|c|c|c|c|c|c|}
\hline \multirow{4}{*}{ Impact Factor: } & ISRA (India) & $=3.117$ & SIS (USA) & $=0.912$ & ICV (Poland) & $=6.630$ \\
\hline & ISI (Dubai, UAE & $=0.829$ & РИНЦ (Russia & $=0.156$ & PIF (India) & $=1.940$ \\
\hline & GIF (Australia) & $=0.564$ & ESJI (KZ) & $=8.716$ & IBI (India) & $=4.260$ \\
\hline & JIF & $=1.500$ & SJIF (Morocco & $=5.667$ & OAJI (USA) & $=0.350$ \\
\hline
\end{tabular}

Общественные и межличностные коммуникации также требуют своего рыночного выражения. Биологические и социальные особенности человеческой реальности многогранны. Они не заданы однажды и навсегда, прирастают, возникают синтетические формы проявления. Так что перспективы рынка естественнонеобходимых товаров и услуг обеспечены, как и рыночной конкуренции, следующей в фарватере своей функции способствовать массовой доступности покупателей к предлагаемой продукции.

Развитие рынка идет согласованно с развитием человека, его личностного выражения, новыми трендами социального движения. К традиционным секторам рынка XX век добавил спорт, научную деятельность, космос, кинематограф, международный туризм. Террор трансформировался в терроризм во многом благодаря проникновению на рынок. Рыночными услугами террористов активно пользуются США, региональные государства для укрепления своего политического положения. Особенно, когда подобные действия оказывают желательный эффект на традиционные рыночные и биржевые торги, к примеру углеводородами.

Развитие рынка идет в направлении возрастания его автономии. Этому вектору уделяют особое внимание представители финансового капитала, отлично сознающие, что рынок представляет оптимальные предпосылки для спекулятивных акций. Наконец, рынок в XX столетии стал любимым предметом экономической науки, стремящейся доказать, что в рынке сосредоточены силы движения экономики. Рынок стал символом новой экономики, её лидеры не против придать данному символу масштаб общественно-исторической значимости. Стремление представить современное общество как «общество потребления», «постиндустриальное общество» нужно понимать именно так.

Рынок не только место где спекуляция приобрела размер массового законного явления, он сам со временем сделался предметом спекуляции. Рыночная спекуляция и спекуляция на феномене рынка - объективная реальность, с необходимостью порождающаяся рынком, его, так сказать, обратные стороны, издержки развития.

Сколь бы не были значимы для истории рынка естественно - необходимые товары, гарантирующие устойчивость рыночного движения в обозримой перспективе, не надо переоценивать значимости их естественной необходимости. Естественная необходимость товарного ряда указывает на природу, характеризует существо предмета. Но природа и сущность товара непосредственно не выступают, они опосредуются явлением, преобразованной производством формой существования материала.

Низкие температуры, высокая влажность, необходимость защититься от травмы, соответствовать рабочему месту и специфике исполнения служебных обязанностей, приведут человека в магазин и сделают его потенциальным покупателем товара, которого ему не достает, но заставят приобрести лишь в одном случае, если ничего иного нигде не окажется.

Такая ситуация не совсем сказочная, однако выглядит несколько неправдоподобно для современной России. Выбор у нашего покупателя есть, как по цене, так и по привлекательности. 9 из 10 выбирают прежде всего по цене, исходя из содержимого кошелька, потом уже ориентируясь на удовлетворение эстетических претензий.

Продавцы могут не паниковать, никакой кризис не лишит рынок клиентов. Их проблема: у кого именно потребитель купит. Купит он то, в чем он увидит сочетание необходимости приобрести товар, свободных финансовых средств, точнее, цены на ценниках, и внешности товара, включая сюда искусство обслуживания. Формула покупки проста - «актуальность потребности плюс очаровательность предложения». Конкретным содержанием слагаемые должны наполнять специалисты, опираясь на опыт рыночных отношений. От себя напомним, что востребованность на ординарном, не эксклюзивном, авторском, рынке, бывает двух видов: естественная и искусственная, спровоцированная обещаниями производителей и рекламным процессом.

Отечественный потребитель, подсаженный на эффект «поп-культуры» «массмедиа», растерял самостоятельность вкуса вместе со способностью размышлять. Национальный колорит в значительной мере утрачен, процветает культ глобальности, рынок завален иностранным ширпотребом и контрафактной продукцией, к которой невозможно приложить качественную оценку.

На рынке складывается специфическая культурная картина, сложная для понимания. Культурой покупателя государство всерьез не интересуется. Прежний опыт культурного просвещения и воспитания изгнан. «Свято место пусто не бывает» и вместо государства пришли организации из структуры гражданского общества, у которых нет ни официальных полномочий, ни действенных механизмов, ни требуемых финансовых средств. Ученые экономисты убеждают предпринимателей, что нужно отсекать все, не входящее непосредственно в производство, сокращая расходы, повышая рентабельность. Поступая так, предприниматели загоняют себя в ловушку 


\begin{tabular}{|c|c|c|c|c|c|c|}
\hline \multirow{4}{*}{ Impact Factor: } & ISRA (India) & $=3.117$ & SIS (USA) & $=0.912$ & ICV (Poland) & $=6.630$ \\
\hline & ISI (Dubai, UAE & $=0.829$ & РИНЦ (Russia) & $=0.156$ & PIF (India) & $=1.940$ \\
\hline & GIF (Australia) & $=0.564$ & ESJI (KZ) & $=8.716$ & IBI (India) & $=4.260$ \\
\hline & JIF & $=1.500$ & SJIF (Morocco) & $=5.667$ & OAJI (USA) & $=0.350$ \\
\hline
\end{tabular}

стихийности и капризов рыночной стихии, отказываясь от рычагов управления спросом.

«Рачительная экономка», приходящая на смену нынешнему нерационально устроенному массовому производству, ориентированному на абсолютизацию свободы выбора товара потребителем, когда ассортимент обязан удовлетворять запрос здесь и сейчас, иначе продавец потеряет клиентов и поставит под вопрос продолжение своего бизнеса, «завязана» на знание потребности конкретного покупателя. Разумеется такое знание специфично, оно ориентировочное, относительное, условное, больше похоже на знание предположение, но всетаки знание в отличие от абстрактной установки типа: покупатель пришел за товаром и он должен его купить, мы же обязаны ему помочь. Как конкретно? Не знаем, поэтому инициируем его желание ассортиментом. Определенная логика и этика в подобных размышлениях присутствуют. Сдерживает от поддержки цена этой логики высокий уровень издержек и нагрузки на естественную среду. Их ведь не спишут, распределят по потребителям, увеличив цену покупки.

Привлекательность товара способна стать магнитом, инициирующим интерес покупателя. Недаром В.И Даль толковал «привлекательность» как «притягательность», «магнетизм». Экономическая система формируется производственными отношениями, радикальных преобразований существующей системы экономики поэтому не будет, произойдет перестройка, перезагрузка, изменяющая не систему, а порядок функционирования системы, векторная эволюция экономической политики. Экономическая система пройдет оптимизацию путем рационализации затрат, минимизации расходов на ассортимент.

Выигрывает ли потребитель? Видимо, да, при условии, что производители и продавцы не поскупятся на исследовательские работы потребительского спроса. Здесь уже простейшими исследованиями не обойтись, потребуется глубокий анализ и комплексирование разных подходов экономического (маркетингового), социологического, культурологического, эргономического, сангигиенического, акцентирование научных исследований на региональные, национальные особенности. Откроется перспектива реального участия в процессе студентов разного уровня, ускоряя их квалификационное становление.

Переход от хорошего к лучшему в любой сфере деятельности сопряжен с увеличением затрат на осуществление, в том числе и финансирования рисков. В нашем представлении, анализируемый переход к новой экономической политике должен оправдать возлагаемые ожидания - привести к сокращению затрат, потерь, экологической нагрузки, но итог во многом будет он определятся построением научно-технической и образовательнопросветительской политики. Благие намерения нередко из-за, некачественного управления завершаются худшими результатами.

Дурной опыт прошлого описан даже в священных книгах. Модификация экономики массового производства в lean production предполагает мобилизацию научно-технической инициативы, максимального подключения культурных активов и реализации советского опыта просветительской работы в среде непосредственных потребностей конечного товара. Нелогично совершенствовать принципы и формы организации производства, рассчитанного на массовое потребление, без соответствующей подготовки потребителей. Прилагательное «массовый», вне зависимости от желаний, свидетельствует о включении деятельности в политический процесс, требующий и политического масштаба участия. Смена курса внутри экономической системы есть политический процесс с той спецификой, что он начинается в экономике.

Пришла вновь пора временно отключиться от производства товаров и, по примеру К. Маркса, сосредоточиться на клеточке современного экономического организма товаре, но, в отличие от автора «Капитала» поместить товар не в производство, а попытаться вписать его в подсистему рыночных отношений. Капитал без обращения не капитал. Капитал - это процесс. Процесс воспроизводства капитала характерный способ его существования. Рынок обеспечивает воспроизводство капитала, создавая условия реализации товарной продукции. Для производства необходим исходный капитал в финансовой форме, для реализации, как условия воспроизводства, требуется востребованность товара, которую должен обеспечить рынок условие, связывающие производителя с потребителем. Все, как видим, упирается даже не в характеристику товара, а в организацию рынка. Разумеется, и свойства товара здесь важны. Доктор способен реанимировать умирающего, но оживить труп не в состоянии. Тоже можно сказать и о рынке.

Что же касается культурной организации рынка, то ее стержнем рационально сделать работу с покупателем и производителем, реальным предметом (объектом) отношений, которых является товар, как совокупность свойств, способных удовлетворить всех субъектов рынка. Товар перейдет из собственности одного в собственность другого только при наличии консенсуса. Консенсус и 


\begin{tabular}{|c|c|c|c|c|c|c|}
\hline \multirow{4}{*}{ Impact Factor: } & ISRA (India) & $=3.117$ & SIS (USA) & $=0.912$ & ICV (Poland) & $=6.630$ \\
\hline & ISI (Dubai, UAE & $=0.829$ & РИНЦ (Russia) & $=0.156$ & PIF (India) & $=1.940$ \\
\hline & GIF (Australia) & $=0.564$ & ESJI (KZ) & $=8.716$ & IBI (India) & $=4.260$ \\
\hline & JIF & $=1.500$ & SJIF (Morocco) & $=5.667$ & OAJI (USA) & $=0.350$ \\
\hline
\end{tabular}

призван обеспечить рынок. Консенсус - мера рыночной культуры.

Когда же на рынке перейдут от представления о консенсусе к пониманию консенсуса, рынок обретет статус «культурной организации». Можно ускорить этот процесс? Безусловно. Нужно организовать работу на обоих фронтах. И покупатель, и продавец должны быть подготовлены культурно к встрече на рынке. Выполнение действительной миссии рынка определяется качеством информационнонаучного его оснащения.

Социальная функция рынка удовлетворение социокультурных и естественнонеобходимых потребностей массового покупателя, способствуя тем самым национальному развитию и политическому прогрессу. Экономическая задача товарного рынка - вовлечь в производство финансовые резервы населения страны, а они немалые, реально сравнимые с годовым бюджетом России.

Управлять рынком возможно. Япония и Китай экономически различны, однако, несмотря на это, успешно управляют и производством и рынком. Управление рынком отличается от управления производством. Рынок сложнее устроен и разнонаправленно реагирует на стремление навести порядок. Порядки ведь тоже неоднородны. В театре один порядок, на скачках - другой, в казарме - третий. Управлять рынком можно (и желательно) экономически.

Конечный этап рыночных отношений реализация товара, следовательно управлять рынком следует через условия реализации товара, создавая благоприятные условия востребованности товара. Такое управление эффективно и в отношении потребителя, и производителя. Построение рынка по принципу: «здесь и сейчас покупатель должен удовлетворить свой запрос», экономит время и возможно незначительные финансовые средства потребителя, но противоестественно, ибо расточительно для общества и природы. Это «пижонство» по причине политической близорукости.

Не откажись от него, общество поставит в ответственное положение следующие поколения людей. Под вопросом окажутся будущее страны, народа.

Переход к производству, ориентированному рынком на структуру конкретизированного потребления, можно рассматривать как способ разрешения усиливающегося противоречия между растущими социокультурными потребностями и естественными источниками. И в этом смысле есть достаточно оснований говорить об объективной закономерности развития воспроизводства. Центр концентрации деятельности смещается на территорию рынка, актуализируется его научный потенциал. Вопрос №1 lean production: готов ли рынок к увеличению ассигнований на исследования структуры потребностей массового покупателя? Отдельные примеры найти нетрудно. Google в конце июня 2017 года провел опрос кулинарных предпочтений россиян с целью составить рейтинг базовых 20 продуктов и такого же количества блюд. Вкус российских потребителей обнадежил маркетологов и привел в ужас диетологов. Тем не менее, специалисты убеждены, что за два-три года изменений не произойдет. Производство, обеспечивающее продуктовый рынок, получило необходимую информацию к размышлению о направлениях инвестиций в производство. Теперь важно избежать ажиотажной перестройки, договориться о квотах внутри соответствующих союзов, ассоциаций и прочих объединений производителей.

Нас исследование известной фирмы заинтересовало в контексте задач общего плана, так как оно высветило несколько характерных оснований для размышления. Первое и, наверное, самое важное наводит на вывод о том, что экономисты-теоретики опять опоздали и вместо прогноза зафиксировали реальный факт существующей действительности. Рынок, обеспечивающий потребности массового покупателя, не был и неясно, когда будет соответствовать моделям маркетологов. Он сам себя формирует, приспосабливаясь к реалиям производства.

Отечественный покупатель на первое место поставил куриное яйцо, в середину отправил свинину и еще дальше молоко. Производство куриного мяса и яиц наладили еще в 1970-80-е годы, растеряли в 1990-е, спасая американских фермеров, вернулись позже к собственному хозяйству, быстро восстановили в нужных объемах. Рынок надежно обеспечен этой продукцией в ассортименте. Цены держатся, производитель, продавцы их не могут чрезмерно завышать - нет дефицита, создана сеть магазинов производителями. Разнообразный ассортимент, своевременное его пополнение, качественность, ценовая доступность продуктов формируют интерес к ним покупателя. Производство свинины также начали наращивать еще в дореформенное время, своеобразие выращивания свиного стада позволяет решать проблемы относительно быстро.

Сложнее всего с молоком. Рыночный либерализм больнее всего ударил по самому слабому звену сельхозпроизводства - молочному стаду. Оно и до девяностых было в массе в запущенном состоянии. Колхозы упразднили, фермерство, призванное поднять производство, не состоялось, как задумывали. Биология КРС такова, что нужного объема стада животных с 


\begin{tabular}{|c|c|c|c|c|c|c|}
\hline \multirow{4}{*}{ Impact Factor: } & ISRA (India) & $=3.117$ & SIS (USA) & $=0.912$ & ICV (Poland) & $=6.630$ \\
\hline & ISI (Dubai, UAE & $=0.829$ & РИНЦ (Russia) & $=0.156$ & PIF (India) & $=1.940$ \\
\hline & GIF (Australia) & $=0.564$ & ESJI (KZ) & $=8.716$ & IBI (India) & $=4.260$ \\
\hline & JIF & $=1.500$ & SJIF (Morocco) & $=5.667$ & OAJI (USA) & $=0.350$ \\
\hline
\end{tabular}

удовлетворительными характеристиками следует ждать не менее 10 лет. Инвестиции требуются огромные! Запад не заинтересован в нас как конкуренте. Все перечисленное - это условия нестабильности и дефицита. Рынок сориентировался под дефицит и навел в кооперации с молокозаводами свой ценовой порядок. Молоко, доступное и качественное в трудные советские годы, стало и некачественным, и малодоступным рядовому массовому покупателю. Особенно изделия из молока. Потребителя рынок отучил от молока. Возникает вопрос. Почему? Рынок должен быть заинтересован в покупателе. Правильно, но в производстве и на рынке работают неглупые люди. Они понимают, что стадо КРС еще долго будут формировать. Неопределенное время получения результата достаточно, чтобы взять наибольшую маржу, а на массового потребителя рассчитывать не обязательно.

Второе, естественные и социокультурные потребности формируются стихийно только в самом общем, абстрактном виде. Конкретизируются же они в реальных условиях национального воспроизводства, на результатах экономической политики. Государство в состоянии воздействовать на этот процесс через контроль за производством и потреблением, разумеется, в соответствии с законами экономики.

Если не управлять, то, как минимум, знать товарную рациональность и ассортиментную архитектуру рынка посредством исследования потребительских предпочтений вполне реально. Экономические, социологические и психологические инструменты позволяют это осуществить. Надо только суметь «заглянуть в душу» потенциального клиента рынка, заставить его раскрыться. Требуется общая среда, создающая атмосферу доверия. Анкетирование изрядно надоело публике, что объяснимо. Эффективность не просматривается, вопросы часто не понятны, техника расспроса примитивная, без приложения к процессу. С другой стороны, проводящиеся акции «sale», не используются для анкетирования. Анкетирование покупателя в специфических условиях продажи, в зависимости от возможности сократить свои расходы, специалистами, а не случайными встречными, естественно располагает к взаимности. Анкету надо попробовать сделать частью акций. Почему бы не проводить в специализированных магазинах «дней покупателя» с широким привлечением представителей заинтересованных организацией. Составлением вопросов для анкетирования и интервьюирования также должны заниматься не случайные «научные подразделения», работающие под любой заказ. Нужны постоянно действующие, специализированные по основным секторам потребительского рынка, исследовательские центры, периодически производимые анализ состояния покупательских интересов. Причем требуется очень высокая аналитическая и методологическая квалификация работников таких центров. Нет никаких сомнений, что сокращение потерь, ускорение товарооборота значительно превысит затраты на деятельность данных подразделений.

Нынешнее состояние изучения потребительского спроса пропорционально расходам на его осуществления. Если статистические методы, как правило, пребывают в удовлетворительном состоянии, они заимствованы в математике, то методология разработки опросных листов, анкет вызывает немало вопросов. Формулировка вопросов свидетельствует о слабом представлении о структуре и специфики деятельности мышления homo sapiens. Как, к примеру, понять «ощутимость потребности в покупке товара», в каких единицах можно измерить это ощущение. Ощущение боли говорит врачу о возможном заболевании. Оно различно и по характеру, и по силе, и по течению во времени. Ощутимость потребности вначале следовало бы дифференцировать и только, получив конкретную картину вариантов насыщенности чувства, вводить в информационный оборот, опрашивать. Отсутствие предварительной, подготовленной к оценке ощущения работы с клиентом обернется некачественным ответом, в котором респондент меньше всех остальных будет виноват, - нужно уметь спрашивать. В ходе интервьюирования оплошность - в постановке вопроса можно исправить, наводящими дополнительными вопросами, в анкетировании подобной возможности нет.

Вопросы по содержанию пересекаются, повторяют друг друга. Так вопросы: «Ответственность производителя за качество товара» (кстати, спрашивать излишне, ибо она четко прописана в условиях купли - продажи) и «впечатляющий гарантийный срок» дублируют один другого. Последний действительно важен. В общей анкете соседствуют частные вопросы, помогающие оценить состояние потребительского отношения и синтезирующие, которым место не в анкете, а в анализе того, кто будет оценивать ответы и делать экспертное заключение. Например, вопрос «Культурное обслуживание» не следовало бы в анкету вводить в такой постановке. Его обычно разделяют на подвопросы, чтобы респондент не знал и не был ангажирован предварительно. О культуре судить придется тому, кто исследование заказывал.

Нередко вопросы загоняют сознание в тупик и надолго. Как понимать вопрос: «Уровень 


\begin{tabular}{|c|c|c|c|c|c|c|}
\hline \multirow{4}{*}{ Impact Factor: } & ISRA (India) & $=3.117$ & SIS (USA) & $=0.912$ & ICV (Poland) & $=6.630$ \\
\hline & ISI (Dubai, UAE & $=0.829$ & РИНЦ (Russia & $=0.156$ & PIF (India) & $=1.940$ \\
\hline & GIF (Australia) & $=0.564$ & ESJI (KZ) & $=8.716$ & IBI (India) & $=4.260$ \\
\hline & JIF & $=1.500$ & SJIF (Morocco & $=5.667$ & OAJI (USA) & $=0.350$ \\
\hline
\end{tabular}

заинтересованности производителя в формировании привлекательности товара»? Он какое отношение имеет к покупателю? Требует разъяснения и вопрос «Завершенность товара»? Двух - трех подобных вопросов хватает, чтобы отвратить покупателя, насторожив его.

Анкеты слабо структурированы, складывается впечатление, что вопросы расположены по мере их придумывания. Например, часто вопросы, цель которых является развернуть готовность клиента сделать покупку, определить степень «зрелости клиента, стоят рядом в общем разделе с вопросами, направленными на установление рейтинга информационных источников. Вопрос о возможности последующего обмена (регулируемого в правовом порядке) явно лишний в анкете, тем более в соседстве с вопросом о современном дизайне. Ставит в ступор вопрос типа: «Потребности у потребителя в покупке привлекательного, оригинального товара?» Здесь сочетается бессмысленность с бесполезностью.

Составление анкеты - искусство, доступное не каждому специалисту. Лучшее, когда над разработкой анкеты трудятся команды специалистов и консультантов, советников. Мы можем только предположить вариант структуры анкеты, направленной на выявление места и роли в индуцировании сознания покупателя на приобретение товара его привлекательности. Нам представляется, что такая анкета должна состоять из 3-х разделов:

- первый образуют вопросы, призванные раскрыть степень готовности сознания потребителя к покупке товара данной группы;

- второй, - помочь определить

привлекательность того в товаре, что приводит потребителя в состояние покупателя, конкретизирует предметно настроение его сознания, определяет выбор;

- $\quad$ третий - понять, что может помешать реализовать потребителю стать покупателем, исключить факторы негативного воздействия на потенциального покупателя.

Редкий товар способен зомбировать потребителя, заставить его не думать и не чувствовать ничего, кроме того, что он держит в своих руках. Такой товар должен сочетать все признаки идеальной степени, быть во всем совершенным. Основную опасность для отказа от, казалось бы, решенного вопроса о покупке обычно создает поведение продавца, нарушение культурного порядка - признаки отсутствия заинтересованности оператора в продаже товара. Потенциальное решение о покупке субъективно и, как таковое, нуждается для объективизации свершения покупки - в определенных условиях, показывающих взаимность интересов сторон сделки. Культура обслуживания покупателя иногда значимее, чем привлекательные признаки товара. К сожалению, у нас еще не вросло в сознание продавцов понимания того, что их действия - составная часть привлекательности изделия. Они думают, что зеркало - это зеркало, а лицо - лицо, не понимая, что изображение лица в зеркале объединяет качество зеркала с качеством лица в едином образе.

В контексте философской характеристике привлекательности товара особо интересна первая группа вопросов, позволяющая мониторить движение сознания. Здесь, повидимому, нужно выделить четыре фазы:

- потребность в товаре на уровне чувствования (хотения);

- интерес на уровне системной оценки возможности покупки;

- созревание актуальности приобретения;

- суперзрелость, заставляющая привлекать кредит.

Идеальным решением проблемы привлекательности было бы сонаправленное взаимодействие трех субъектов наподобие гоголевской «птицы - тройки» - производителя товара, он играл бы роль «коренника», и «пристяжных» - покупателя с продавцом. Так могло бы быть, если бы каждый из тройки работал автономно в своих собственных интересах, причем производитель и продавец, проявляли при этом все признаки высокой профессиональной культуры. Определение «идеальное решение» мы используем в его базовом практическом смысле, как совершенный способ осуществления идеального соображения, то есть то, что объективно реально достижимо. Системообразующим признаком философии организации воспроизводства было и будет положение: « потребитель (покупатель) всегда прав». Именно в нем заложена профилактика, не позволяющая воспроизводству сойти с магистрального прогрессивного продвижения вперед.

Противоречия

действительности сдерживают движение по идеальному маршруту. В общественной жизни движение идет в условиях взаимопересечения объективных предпосылок и осознания их в человеческих интересах. Человеческие интересы определяются местом положения человека в структуре социальной архитектонике. Еще Л. Фейербах сделал вывод: «В хижинах думают не так, как во дворцах». А К. Маркс и его сторонники убеждали, что конценсуса обитателей хижин и дворцов ждать бесполезно. Каждый будет биться за свою правду, не взирая на объективную несостоятельность до конца. Речь идет не только 


\begin{tabular}{|c|c|c|c|c|c|c|}
\hline \multirow{4}{*}{ Impact Factor: } & ISRA (India) & $=3.117$ & SIS (USA) & $=0.912$ & ICV (Poland) & $=6.630$ \\
\hline & ISI (Dubai, UAE & $=0.829$ & РИНЦ (Russia) & $=0.156$ & PIF (India) & $=1.940$ \\
\hline & GIF (Australia) & $=0.564$ & ESJI (KZ) & $=8.716$ & IBI (India) & $=4.260$ \\
\hline & JIF & $=1.500$ & SJIF (Morocco) & $=5.667$ & OAJI (USA) & $=0.350$ \\
\hline
\end{tabular}

о крайних формах политической борьбы. Их крайность показывает, что они эксклюзивные. В обычной жизни общества много ординарных путей достижения своих классовых, национальных, политических и экономических целей. Идеология призвана по разному защитить интересы тех, кто её финансирует.

Тезис «Покупатель всегда прав» - надежное прикрытие, призванное создать впечатление о гуманности демократического устройства социального организма. Практически на рынке господствуют продавцы в союзных отношениях с производителями. Производители изготавливают не то, что могут, а преимущественно то, что особенно рентабельно. Берут они в расчет конъюнктуру рынка? Бесспорно, но не в качестве интересов потребителя как мерила своей деятельности. Производители знают, что рыночные порядки опять-таки определяются не потребностями покупателей. На рынке правит продавец в лице организатора - хозяина - рынка. Хозяин же рынка, в свою очередь отлично знает о значении для его благополучия сотрудничества с производителем. Так и получается, что из рыночного "божества" покупатель превращается в крайнего субъекта рынка, мышлением и кошельком которого манипулируют все, включая и государственные службы. Рыночный порядок в "культуру рынка" складывается не за четверть века демонстрации поиска цивилизованных механизмов в условиях экономической нестабильности.

Рынок, взятый абстрактно, в виде необходимого звена товарного воспроизводства, понятие для политико-экономического мышления ясное и важнейшее, указывающее на роль рынка в обеспечении устойчивости общественного прогресса. Этой значимостью рынка и спекулируют те, кто объективирует, материализует понимание, трансформирует его в социально-экономическую реальность. Понятия экономической теории культурное оформление имеют в рамках самых общих требований, обеспечивая воспроизводство в его принципиальном выражении. Это уровень культурной абстракции.

Реальный рынок определяется наличным культурным оснащением общества. Здесь культура конкретизируется исторически во времени и пространстве. Что вырастили, то и получили на рынке. Добавим к сказанному ещё и значение отношения к культуре. Одно дело понимать культуру ординарным фактором, совсем другое, видеть в культуре источник общественного развития.

Вещий Олег у А.С. Пушкина удивился пророчеству волхвов относительно причины своей смерти. Кто-то, наверняка, прочитав следующее, вспомнит об удивлении князя русичей. Способность удивляться - признак активности мышления, аргумент в пользу креативности сознания, но она требует осторожности и знания, а не мнения. В стремлении познать, что не придает товару привлекательность, логично вышли на оригинальность изделия. Разбираясь с понятием «оригинальность», вспомнили о «вычурности». Прогресс осуществляется по спирали, поэтому возвращение к прошлому, подзабытому, естественно. В свое время понятие «вычурность» было обыденным, термин часто употребляли отечественные классики: В.Г. Белинский, Н.В. Гоголь, И.С. Тургенев, Ф.М. Достоевский. Интересно, что никто из них не использовал «вычурность» в положительном значении. Под вычурностью понимали опасное отклонение от культурной нормы, подчеркивая необходимость деликатного обращения с этим словом. В. И. Даль также, похоже, не пришел к единому отношению к содержанию понятия «вычурный», предпочтя читателям дать самим подумать как они будут оперировать термином. Даль только вполне определился с происхождением слова. «Вычурный» от глагола «вычурать», а изначально от «чур» («в играх: изыть, что от чего, оградить себя самого (или вещь) «заговором»). «Вычурный, по Далю, узорочный, резкий, пестрый, с прикрасами; изысканный, странный...» [3, с.326].

Содержание понятий и отношение к понятиям со временем изменяются, иногда даже на противоположную точку зрения. Мы сравнили толкование вычурности В.И. Даля с разъяснениями в «Словаре русского языка», изданном АН СССР: «вычурный» замысловатый, излишне затейливый, чрезмерно украшенный [4, с.387]. Литературные примеры, взятые у Белинского, Достоевского и Никулина, подобраны так, чтобы подчеркнуть негативность присутствия в вычурности этого излишка. За полтора столетия, как видим, особых перемен в понимании «вычурности» для культурного статуса понятия «вычурный», не случилось.

Вычурность - удел опытных, мастеровитых художников. Одно можно сказать с уверенностью, вычурность предполагает эксклюзивность товара. Массовый товар исключает вычурность, так как рассчитан на потребителя стандартного культурного вкуса. Массовый потребитель вычурности не поймет без предварительного разъяснения, но тогда вычурность теряет смысл как «нечто сверх того, что есть». На эффект вычурности вправе надеяться менеджеры бутиков. У них специфический покупатель. Вычурность - стихия стилистов, состоявшихся модельеров, причем не всех, а только тех, кто не переступил порог меры, тонко чувствует границу дозволенного 


\begin{tabular}{llllll} 
& ISRA (India) $=3.117$ & SIS (USA) $=\mathbf{0 . 9 1 2}$ & ICV (Poland) & $=\mathbf{6 . 6 3 0}$ \\
Impact Factor: & ISI (Dubai, UAE) $=\mathbf{0 . 8 2 9}$ & PUHЦ (Russia) $=\mathbf{0 . 1 5 6}$ & PIF (India) & $=\mathbf{1 . 9 4 0}$ \\
& GIF (Australia) $=\mathbf{0 . 5 6 4}$ & ESJI (KZ) $=\mathbf{8 . 7 1 6}$ & IBI (India) & $=\mathbf{4 . 2 6 0}$ \\
& JIF & $=\mathbf{1 . 5 0 0}$ & SJIF (Morocco) $=\mathbf{5 . 6 6 7}$ & OAJI (USA) & $\mathbf{0 . 3 5 0}$ \\
\hline
\end{tabular}

вторжения личной фантазии в сформировавшееся многообразие вкусов. И вновь на нашем пути оказывается философская позиция художника, стоящего перед выбором: делать для кого и для чего? Потому как его будущее зависит от того, кто в нем окажется, ценители или потребители творчества. История свой приговор вычурности вынесла еще в начале просвещения. Вычурность связали с прошлым, оставив место в будущем вычурности не как продукту, а как творческому приему поиска «продуктивного» мышления. Вычурность нормальна для фантазии в тестовом выражении с целью определить реакцию на нововведение, авангардную деталь. На склонение к вычурности следует смотреть через призму судьбы авангардных течений.

Они после себя оставили идеи, технические инструменты. Спрос на авангардную продукцию был эстетически вычурным, определялся размером свободных финансов и остался явлением эксклюзивным. На востребованность вычурной продукции в массовом масштабе можно рассчитывать кратковременно, и после тотальной обработки массового потребителя средством масс-медиа. Понятно, что и потребитель здесь специфический с несформировавшейся культурой мышления, ищущий не ответы на вопросы, а подсказки, что именно и как надо сделать. Судя по парадигме отечественной модификации модернизации образования, на ближайшую перспективу производители вычурной продукции могут надеяться, если правильно сориентируют цены. Логика чувственного мышления «железной» представляется в сознании и легко разбивается о практические утесы. Одни из них - размер маржи союза «производитель-продавец».

Рынком, как спросом, так и ассортиментом предложений, активно пользуются политики, главным образом в периоды общественной неопределенности. В частности, в наши дни, правители и их идеологическая опора на Украине. Вышитые национальным узором рубахи до майдановских событий 2014 года, спровоцированных участием радикальных националистов нацистского толка, хранились в сундуках, да кое-где висели по хатам в виде реликвий по углам. Когда же потребовалось активизировать национальный дух свободолюбивого украинского народа, то Рада расцветилась вышивалками. А демократическая Европа, давно определившая для себя нормальный деловой вид костюма для официального присутствия в органах государственной власти, сделалась слепой, не увидела столь очевидной националистической акции.

Вспомним рождение нацизма в Германии. Германский крайний радикализм родился в коричневой униформе. Политикам, стремящимся к переворотам, чаще всего нужна вычурность. Во-первых, чтобы добиться единообразия рядов, их сплоченности, во вторых, для противопоставления существенному порядку, с которым они собираются бороться.

Наряду с негативными примерами использования «вычурности» в одежде, экипировке, есть и положительный опыт скаутское движение в США, пионерское - в СССР. Какой можно сделать вывод из анализа политических перспектив дизайнерского творчества в форме создания вычурности продукта? Заключение напрашивается одно: существует «диалектика» единичного и общего, обычно она складывается через «особенное». Спор о примате «единичного» и «общего» давний. Восходит к Платону и Аристотелю, был основой средневековой схоластической идеологией, разделив ее на «номиналистов» и «реалистов». Диалектик Гегель на уровне философского - метафизического мышления, рассматривал что есть что и как они связаны в развитии, естествознанием подтверждено диалектическое понимание единства «единичного» и «общего». Но, одно дело умозрение, другое практически ориентированное осознание, называемое «здравым смыслом». «Здравый смысл» - донаучная форма производства знаний. Она привлекает простотой получения их, удобством применения, однако ее обратной стороной является опасность заблудиться по мере погружения в процесс познания, подмены знаний мнением. Всем этим нечистоплотные политики и пользуются в своих приватных интересах. Вычурность в творчестве явление нормальное, свидетельствующее о рабочем состоянии мыслей. Нужна, однако, и творческая бдительность, не допускающая «вычурный бум». Всему должно быть свое новое место. Производители призваны не ограничиваться удовлетворением практического спроса массового покупателя, воспитываемого рекламным прессингом. Они своим социокультурным статусом призваны формировать вкусы и эстетические приоритеты потребителей в контексте национальных и общечеловеческих традиций.

«Привлекательность товара» - понятие и для производства, и для науки сравнительно новое. Оно требует системного исследования, что предполагает обращение к теории понятийного мышления. Экономическая деятельность осуществляется, опираясь на здравый смысл, извлекаемый из многолетнего опыта, и на обобщение практики в научных понятиях. Научное знание прирастает понятиями! Здравый смысл заслуживает высокой оценки, но он ориентирует только в ограниченных 


\begin{tabular}{|c|c|c|c|c|c|c|}
\hline \multirow{4}{*}{ Impact Factor: } & ISRA (India) & $=3.117$ & SIS (USA) & $=0.912$ & ICV (Poland) & $=6.630$ \\
\hline & ISI (Dubai, UAE & $=0.829$ & РИНЦ (Russia) & $=0.156$ & PIF (India) & $=1.940$ \\
\hline & GIF (Australia) & $=0.564$ & ESJI (KZ) & $=8.716$ & IBI (India) & $=4.260$ \\
\hline & JIF & $=1.500$ & SJIF (Morocco) & $=5.667$ & OAJI (USA) & $=0.350$ \\
\hline
\end{tabular}

непосредственным опытом пределах. Теоретическое осмысление на уровне научной методологии раздвигает наличные рамки, открывает перспективу. Оно более надежное и универсальное.

Надежность и универсальность - признаки качества знаний. Надежность позволяет свести к минимуму риски, универсальность снимает напряжение с поиска новых решений проблемы «от добра добра не ищут». За качество приходится платить. Плата, как принято считать, имеет финансовую зависимость, однако это не всегда выглядит непосредственно. В истории цивилизации есть два выдающихся достижения на уровне революций, явно не получивших эквивалентной оценки:

- открытие цены знаниям, сопоставимой с ценой для человека вещей, - «знание - сила» и

$$
\text { - осознание особого значения }
$$
теоретических знаний в форме понятий и смежных с ними форм абстрактного мышления суждений, умозаключений, что закономерно привело к необходимости разрабатывать специфическую технологию их производства методологию познания сущности отношений существующих явлений. Видимая часть мира «рассчитана» на потребителя, невидимая - на производителя. Конкуренцию производителей можно формализовать в виде простой технической задачи - проникнуть через хаотическое множество явлений видимой части мира в его скрытую часть, разобраться в ней, чтобы, вернувшись, понять хаос как порядок сосуществования и развития явлений. Упорядоченность и есть закономерность. Законы только в учебниках существуют сами по себе, отдельно. В действительности закон - это устойчивость, общность и необходимость порядка того, с чем мы имеем взаимодействие познаем, воспроизводим, изменяем, управляем.

Экономическая наука в XX веке попала в сложное положение, которое к концу столетия сделалось критическим. Теория А. Смита и метод К. Марка не вписались в контуры идеологии развитого капитализма [1, с. 26-27]. В Европе и Северной Америке сама мысль об историчности капитализма воспринималась как ересь. История капитализма имеет начало, но наличие начала не может быть основанием вывода о конечности. Математика - наука точная, она допускает бесконечность в одну сторону. Диалектическое толкование бесконечности - метафизическое, отвлеченное от реальной истории. Спасение экономической науки надо искать не в историческом, а формально-логическом понимании действительности, то есть в математических исчислениях, статистике [2].

Мы остановим погружение в философские, правильнее сказать, методологические, основания науки, но не потому, что надо быстрее окунуться в практическое дело, а вследствие значимости для успешного осознания производства товара понимания того, что всякое производство предполагает воспроизводство, наряду с товаром, отношений. Производство начинается с достижения определенных отношений и приводит к развитию этих отношений - между производителями, производителями и потребителями. Разобраться в столь сложно выстроенном производстве можно лишь с привлечением научного анализа на основе понятийного мышления.

Вот почему начинать анализ сравнительно нового понятия «привлекательность» в прикладном его конкретном выражении «привлекательность товара», нам придется с теории, логического учения. Альтернативный путь есть, но без источника света, наощупь, в темноте.

Современное знание о понятии; его восхождении от абстрактного к конкретному с последующей перспективой рождения новых понятий как продуктов развития содержания, заложил Г. Гегель. Понятийное мышление, согласно Гегелю, - процесс диалектический. Учение всемирно известного философа опиралось на принципиально новое толкование развития, в основе которого лежала идея внутреннего источника движения, представленного отношениями противоположностей, находящихся в единстве. Предшественник Г. Гегеля, Аристотель, логику мышления выстроил на принципе тождества понятия самому себе, его неизменности. В механической теории такой подход отражен в разделе «статика», и специалист знает, что подобным образом ситуация искусственно упрощается в частных интересах. Однако далее идут наиболее интересные в практическом плане разделы «динамика» и «кинематика». Они описывают уже не момент движения, - в общем виде трактуемый как нечто неменяющееся, покоящееся в своем состоянии, а само движение как изменение в самом широком смысле. До динамики и тем более кинематики мышления в контексте содержательности движения понятий Аристотель не добрался, его, прежде всего, интересовала технология абстрагирования и обобщения в формах знаний. Логику Аристотеля поэтому нередко называют «формальной».

С точки зрения Гегеля, логика Аристотеля была всего лишь частным случаем, имеющим ценность в том, что познанию для того, чтобы встроиться в процесс и провести общую рекогносцировку, важно, пусть и условно, остановить изменение. Аристотель приносил в жертву содержание понятий во имя достижения закономерности формальных отношений. 


\begin{tabular}{|c|c|c|c|c|c|c|}
\hline \multirow{4}{*}{ Impact Factor: } & ISRA (India) & $=3.117$ & SIS (USA) & $=0.912$ & ICV (Poland) & $=6.630$ \\
\hline & ISI (Dubai, UAE & $=0.829$ & РИНЦ (Russia) & $=0.156$ & PIF (India) & $=1.940$ \\
\hline & GIF (Australia) & $=0.564$ & ESJI (KZ) & $=8.716$ & IBI (India) & $=4.260$ \\
\hline & JIF & $=1.500$ & SJIF (Morocco) & $=5.667$ & OAJI (USA) & $=0.350$ \\
\hline
\end{tabular}

Попросту говоря, взгляд на логику Аристотеля, сродни выражению «общий план» на данное время. Прошлое и будущее понятия Аристотеля не интересовало, что, опять-таки, в общем, соответствовало характеру исторического времени. К. Ясперс назвал описываемую эпоху «Осевым временем», подчеркнув роль культуры, как оси, вокруг которой начала раскручиваться Античная цивилизация, но вряд ли надо в его оценке видеть действительный исторический масштаб происходивших перемен, да и само понимание времени греками было циклическим. Одним словом, Аристотель в своей логике воспроизвел дух эпохи, в которой жил и творил. Другое дело Г. Гегель, творивший в условиях расцвета Нового времени с его политическими, научными, техническими, промышленными и культурными революциями. Г. Гегелю необходимо было понять дух времени в контексте радикальных общественных перемен, наполнить содержание понятий движением.

После себя Г. Гегель оставил немало вопросов, поэтому, отдавая должное его диалектическому открытию, следует помнить и о том гегелевском наследстве, которое тормозило распространение диалектики.

Ограничив диалектику сферой духовной деятельности, он признал самодостаточность бытия духа и воспринимал все остальное в форме инобытия духа, разумеется, вне диалектического развития. Триада Г. Гегеля «тезис - антитезис синтез» оказалась не универсальной формулой развития. Существование внедуховных форм бытия - физической реальности человека, природы, общества он объяснял объективизацией духа, отнеся к производным развития духа. Заслуга К. Маркса и Ф. Энгельса состояла как раз в том, что, опираясь на естественно-научные открытия и движения буржуазного способа производства, они сначала перевернули понимание диалектики «с головы на ноги», а затем сняли ограничения с нее и сделали универсальным способом развития.

Реакцией на рационализм Гегеля были и позитивизм, и иррационализм, но они страдали той же «болезнью», что и «больной», односторонностью подхода. Позитивизм явно испытывал ограничения, свойственные эмпиризму, иррационализм был ближе ко времени буржуазной активности, не отягощенной интеллектуальной рефлексией. Идея силы воли, стремления к власти, получила определенную поддержку в развивающемся обществе, несмотря на ряд вызывающих умозаключений с точки зрения культурных традиций.

Подтверждением сказанного служит очередной всплеск интереса в Европе к экономическим исследованиям К. Макса в конце нулевых годов в связи с финансовым кризисом.
Европейцам невдомек, что есть еще одна серьезная монография В.И. Ленина «Империализм как высшая стадия капитализма», в которой автор впервые проанализировал опережающую динамику финансового капитала и отметил откровенное стремление его к политическому влиянию на общественную жизнь.

Диалектическое мышление не пришло в экономику сразу, оно начиналось с отдельных идей, в основном идеи развития. Итальянский экономист А. Серра первым обратил внимание на разделение труда (РТ) и посмотрел на эту особенность экономической деятельности в динамике. Статистически он доказал, что богатство страны прирастает в зависимости от глубины и распространения РТ. У. Петти и А. Смит развернули ракурс вывода А. Серра в транснациональном масштабе. В итоге А. Смит оказался в тупике недиалектических размышлений, - когда РТ охватит экономику всего мира, то развитие остановится? А. Смит и Д. Рикардо воспринимали капитализм тождественно мировой истории, были уверены, что капитализм возник, чтобы быть бесконечным. Экономическая мысль уткнулась в свой предел, ибо не смогла обрести политическое начало равносильное экономическому. К. Маркс предсказал, что логика экономического развития неизбежно приведет к политическим и социальным метаморфозам, настроив против себя апологетов капитализма.

Не случайно в ХX веке политическую составляющую экономической науки энергично выдавливали, наивно полагая, что удастся ограничиться чисто экономически анализом. Саму «очищенную» экономическую науку поделили на макро и микроэкономику, а к XXI веку вообще презентовали как экономиксизм. «Новая экономическая «наука» пишет М.Л. Хазин, создавалась именно как идеологическая альтернатива политэкономии... Для этого пришлось перевернуть построение науки с ног на голову: если политэкономия строится от макроэкономики (т.е. общеэкономических закономерностей, к которым относятся и углубление РТ, и масштаб рынков, и объем совокупного спроса) к микроэкономике (т.е. поведению отдельного человека и фирмы), то в экономиксизме все наоборот, т.е. спецификой экономиксизма является попытка из микроэкономики вывести глобальные макроэкономические закономерности» [2, с. 108].

Теперь представим себе картину специалисты манипулируют исторически сложившейся наукой, вместо того, чтобы совершенствовать ее методологию, производить новые теоретические исследования, достраивать и перестраивать в рамках системного подхода 


\begin{tabular}{|c|c|c|c|c|c|c|}
\hline \multirow{4}{*}{ Impact Factor: } & ISRA (India) & $=3.117$ & SIS (USA) & $=0.912$ & ICV (Poland) & $=6.630$ \\
\hline & ISI (Dubai, UAE & $=0.829$ & РИНЦ (Russia) & $=0.156$ & PIF (India) & $=1.940$ \\
\hline & GIF (Australia) & $=0.564$ & ESJI (KZ) & $=8.716$ & IBI (India) & $=4.260$ \\
\hline & JIF & $=1.500$ & SJIF (Morocco) & $=5.667$ & OAJI (USA) & $=0.350$ \\
\hline
\end{tabular}

апробированные идеи. Спрашивается, зачем? Кому это надо? В теории познания на данные вопросы ответы не предусмотрены. Абсурдность отрицания логического пути движения очевидна, хотя прецеденты имеются. Известные ученые не раз отмечали алогичность достижения сделанных открытий, но они рассуждали о конечном эвристическом звене логически и методически выстроенной цепи познания. Алогичность или, точнее, нелогичность финальных результатов лишь подтверждала перспективы логически организованного мышления в обоих вариантах аристотелевском и гегелевском.

У научных понятий огромный потенциал развития. Системные отношения понятий способствуют появлению и актуализации новых понятий. Новые понятия вполне могут вырасти в системообразующие. С другой стороны, еще Г. Гегель посчитал значимым для правильной ориентации в реальном мире, различать реальнонеобходимое и реально-не необходимое. Первое содержит в себе источник функционирования и развития, поэтому такие явления он называл «разумными» или «действительными», второе же отслужило и, либо тормозит движение, либо противодействует ему.

Создается впечатление, что экономическая наука и на Западе, и в России под воздействием авторитета нобелевских лауреатов, решила, что со смертью Г. Гегеля и К. Маркса скончалась и политическая экономия. Но впечатление это ложное. Заменив приоритет производства в строительстве экономической системы на фактор рынка, современные ученые-экономисты поменяли хозяев. На смену Ф. Тейлору, А. Файоле, Г. Форду, А. Слоуну пришли рыночные спекулянты типа Coppoca, а политические ориентиры у экономической теории сохранились.

Апологеты капитализма в экономической науке хотят поставить капитализм над историей в качестве идеальной модели организации производства. Формально сочетание развитой формы политической демократии, ее правового обеспечения государством, со свободой предпринимательства дает основание на претензию к идеальности. Только давайте не забывать, что все перечисленное идеально выглядит в сравнении с политическими и правовыми моделями абсолютизма, диктатуры и прочими анахронизмами. История не завершается финансово-олигархическим капитализмом с его витринной демонстрацией общества массового потребления. «Кастинг» образцовых социальноэкономических моделей продолжается и будет идти, пока нынешняя модель доступна седьмой части человечества. Шесть с половиной миллиардов тех же homo sapiens по-прежнему могут позволить в лучшем случае купить билет в кинотеатр и посмотреть сладкую жизнь себе подобных. Семеро с сошкой против одного с ложной - пропорция весьма опасная, к тому же и сама цифра семь на особом счету в практике общественного сознания.

Всемирная конференция элиты ученого мира в Рио настойчиво рекомендовала сменить курс с бизнес жадности на устойчивость развития, предупредив, что к обострению внутри человеческих контрастов присоединится глобальный конфликт с природой. Вместо ноосферы будущее поколение, родившееся сейчас, получит противогазы и защитные костюмы, а легкой промышленности придется менять направления развития, чтобы обеспечить исчезающий вид млекопитающих индивидуальными средствами защиты.

Особенности господствующего способа производства безусловно проявляются в развитии экономической науки, однако они не отменяют ее политического статуса. Более того, экономическая наука, прежде чем совершить очередной виток прогресса, объективно обязана определить политические предпосылки подъема способа производства на новую ступень. Попробуйте разобраться, чего больше оставили наследникам А. Смит, Д. Юм, Р. Оуэн, Ж. Сисмонди, К. Маркс, Дж. Милль, Г. Спенсер, Т. Мальтус - социально-политической философии или экономических знаний. В их трудах социальная история переходила в политическую, а политику они понимали в качестве средства и цели экономических программ продвижения в решении проблем общественного развития. Коммунистическая альтернатива буржуазному способу производства объективно пока не вызрела. Стремление разделить историю коммунизма политэкономически на две ступени и и начинать с социалистической было блокировано, с одной стороны политизацией экономики капитализма в направлении усиления социально значимых вех, с другой, - агрессивной экономической политикой, призванной протекционистскими сговорами, и ординарным политическим обманом не в меру доверчивых лидеров коммунистов убедить в экономической несостоятельности социализма. Итина осталась конкретной - политические ресурсы экономической науки обусловлены объективно историческим временем того способа производства, которым она рождена. Экономическая наука едина своей объективностью, но ее объективность отражает исторические эпохи и потому имеет вид цепи, составленной отдельными конкретноисторическими звеньям, закономерно связанными между собой. Возможно временно такие звенья сосуществуют. Подобным опытом был просчитанный В.И. Лениным НЭП, отстаиваемый им в борьбе с соратниками и 


\begin{tabular}{|c|c|c|c|c|c|c|}
\hline \multirow{4}{*}{ Impact Factor: } & ISRA (India) & $=3.117$ & SIS (USA) & $=0.912$ & ICV (Poland) & $=6.630$ \\
\hline & ISI (Dubai, UAE & $=0.829$ & РИНЦ (Russia) & $=0.156$ & PIF (India) & $=1.940$ \\
\hline & GIF (Australia) & $=0.564$ & ESJI (KZ) & $=8.716$ & IBI (India) & $=4.260$ \\
\hline & JIF & $=1.500$ & SJIF (Morocco) & $=5.667$ & OAJI (USA) & $=0.350$ \\
\hline
\end{tabular}

вызвавший подъем хозяйства страны, и официальная политическая доктрина КНР: одно государство - два уклада.

Современная история экономической науки, вопреки многочисленным ухищрениям оппонентов, идет прежним политичеким курсом, деполитизация экономической теории абсурдно выглядит в экономической практике. Достаточно взглянуть на движение валютных курсов, проследить биржевые новости, чтобы оценить силу политического влияния на экономическую деятельность.

Вместе с эволюцией экономической науки меняются и экономические понятия, одни перезагружаются, наполняясь новым содержанием, другие раздвигают ареал приложения, третьи передвигаются на новые позиции, четвертые теряют былую значимость в то время, как пятые появляются, демонстрируя модернизацию экономической реальности. Передвигаясь от понятия к понятию можно повторить историческую логику восхождения производства, определить качественные исторические скачки.

К. Маркс диалектику капиталистического производства развернул с исходного понятия «товар», увидев в противоречиях товара зародыши противоречий способа производства. Но товар не был и не мог быть начальным явлением экономической истории. Товар сам является историческим продуктом. Товар и соответствующее понятие в политической экономике обязаны предшествующему этапу развития экономики. История материального производства стартовала с изготовления продуктов, необходимо связанных с жизнедеятельностью производителя в том виде и количестве, в котором их получали. Проблема отчуждения родилась и стала в ряд базовых в характеристике способа производства позже в связи с возможностью получения продукции сверх необходимости воспроизводства условий продолжения труда. Как бы то ни было, продукт превратился в товар, а процесс отчуждения из социально-политического феномена в экономическую закономерность. Понятие «рынок» также не с небес свалилось. Рынок вырос из случайных форм обмена. По мере обретения некоторой устойчивости, случайность, через промежуточную форму ярмарок, сформировалась в необходимость. Рынок стал основой обменных действий, а ярмарки его дополнением. Природа рынка обусловлена необходимостью воспроизводства. Рынок вписан в процесс производства и все его попытки встать над производством противоестественны. Но само существование рынка как способа удовлетворения условий воспроизводства абсолютно естественно, что позволяет рынку в определенных границах проявлять свое законное положение в производстве. Проявлять же себя, как всем известно, можно по-разному, тем более, что рынок соединяет интересы разных субъектов производства, каждый из которых хочет быть в выигрыше.

Производство объединяет не только технико-технологические действия, их объективно зависимую организацию, оно включает «человеческий фактор», который в последнее время чаще зовут «человеческим капиталом», - так звучит приятнее, вселяет гордость за право быть «человеком разумным», к тому же, почти капиталистом. «Человеческий фактор» более точно описывает происходящее непосредственно в производстве, так как производство можно без остатка разложить на основе понятия «фактор» на составляющие «дидактические» единицы. «Человеческий фактор привносит в производство цель, если повезет с «человеческим капиталом» профессиональной культурой менеджмента, из цели можно «вырастить» целесообразность, то есть системно организовать отношения цели, средств, методов и форм ее достижения, оптимизировать процесс производства. В общем виде производство выглядит как деятельность по превращению цели в результат. Правильный выбор цели производства уже считается первой победой, тем «добрым началом», что в народной мудрости приравнивается к «половине дела».

И все же, «конец - всему делу венец». Цель реализована, получен желаемый результат. Начинается новая история. Результат произведен не для собственного потребления. Чтобы производство не остановилось, а победа не оказалась пирровой, полученный продукт в ранге товара необходимо обменять на необходимые условия продолжения производства. В дело включается рынок, задача которого пристроить товар - найти покупателя. У покупателя, разумеется, свои интересы, возможно не совсем личные, напротив, в первую очередь, производственные. В какой-то мере рынок - это тоже производство, он производит организацию посреднических услуг. Такое производство, правда, больше похоже на эрзац производство, ибо не выполняет функцию создания добавленной стоимости товару, зато активно влияет на изменение цены товара. Само понятие «цена» - рыночного происхождения, поэтому имеет косвенное отношение к коренным понятиям производства «себестоимости» и «стоимости» товара. Цена обеспечивает прибыль рынку. Рынок - заинтересованный субъект процесса ценообразования. Здесь начинается еще одна интересная история для покупателя.

Рынок обладает большими возможностями манипулировать товарами и ценами в отсутствии 


\begin{tabular}{|c|c|c|c|c|c|c|}
\hline \multirow{4}{*}{ Impact Factor: } & ISRA (India) & $=3.117$ & SIS (USA) & $=0.912$ & ICV (Poland) & $=6.630$ \\
\hline & ISI (Dubai, UAE & $=0.829$ & РИНЦ (Russia & $=0.156$ & PIF (India) & $=1.940$ \\
\hline & GIF (Australia) & $=0.564$ & ESJI (KZ) & $=8.716$ & IBI (India) & $=4.260$ \\
\hline & JIF & $=1.500$ & SJIF (Morocco & $=5.667$ & OAJI (USA) & $=0.350$ \\
\hline
\end{tabular}

четкого продуманного и организованного взаимодействия в системе отношений производителей и потребителей. Либеральная политэкономия акцентирует внимание на свободе рынка, не заботясь о содержании понятия «свобода». Произвольно вторгаясь в сферу ответственности философии, либералы делают вид, что решают свои проблемы, вводя в заблуждение профессиональное мышление и общественное сознание. Далеко не все экономисты-теоретики и практики искушены в философской рефлексии. Пользуясь подобным положением, либералы выращивают свое рыночное «понятие» свобода, стараются освободить рынок от подчинения необходимости в любом ее выражении. По сути, экономический либерализм, провозглашенный А. Смитом в конкретном формате, трансформировался в банальный рыночный анархизм. В странах, где сильны демократические традиции, загруженные гуманистическими ценностями и социальной ответственностью, либерализм теряет политические позиции, но у него есть серьезная крыша в лице процветающего финансового капитала, жирующего за счет рынка.

Мы вовсе не хотим лишить рынок статуса субъекта развитого культурно производства. Рынок вне каких-либо сомнений им является, но ставить рынок в общий ряд субъектов производства, следовательно, игнорировать очевидность различного отношения к важнейшему показателю развитости производства - способности трудом наращивать стоимость.

Свобода рынка сравнима со свободой судей на футбольном поле. Судьи не играют, они обеспечивают игру по действующим правилам. Они могут своими действиями тормозить темп, сбивать напор, подыгрывать, однако все это происходит на виду, под общественным и профессиональным контролем и преследуется в установленном порядке.

Обменная функция рынка объективизирует его, только важно помнить о способах проявления объективности. Материальная форма объективности - технико-технологическая объективность производства, физическая реальность товара - действительно первична и подчинена естественному основанию общественной жизни; объективность производственных и экономических отношений, включая организацию и разделение труда, «вторичная» объективность, создаваемая при творческом участии субъектов труда, - это, естественно,-историческая объективность. Есть еще, по-видимому, третий, переходный уровень объективности, опосредованно управляемый объективной природой производства. Рынок принадлежит этому третьему уровню. Отсюда и столь различная реальность рынка, возможность организаторам достаточно произвольно манипулировать в рамках рынка и в интересах рынка. Ф. Энгельс разъяснял Е. Дюрингу: «В обществе, где товарное производство составляет господствующий способ производства, «рынок всегда был ... границей весьма известной среди «деловых людей» [3, с. 239]. Благодаря своей специфической реальности «переходного типа» от жестко регламентированного бытия производства к относительности зависимости условий обмена от естественно-исторической конкретности, рынок сочетает адекватные действительности действия с действиями специфического свойства, организуя из последних свою инфраструктуру. Прикрываются «рыночники» «железным аргументом» - рынок «барометр» состояния производства. В подобном положении все те действия, которые, по классификации Г. Гегеля, не действительны, допускаются как необходимо-условные. Совсем по логике Петцольда, спасавшего махизм от солипсизма путем введения в формулу бытия «потенциального члена «отношения». Петцольд не персонифицировал «потенциального члена», но не составляло труда понять, что им должно быть нечто универсальное, стоящее над субъективной формой сознания. Рыночники, абсолютизируя положение рынка, точнее, обмена посредством рынка, добиваются контроля над производством. Интерес рыночников вновь заставляет нас вспомнить о власти денег.

По своему объективному положению рынок не должен зарабатывать больше, чем производители. В противном случае производство остановится, а вместе с ним и социальный прогресс. Сейчас ситуация критическая, причем первой причиной кризиса является политика финансистов, второй рыночная спекуляция. Цены на реальные товары на рынке давно не соответствуют стоимости их реального производства доставки и расходам продажи. Проблема состоит для либералов в одном - образованности масс. Все таки на улице XXI век. Поэтому и мировая политика в сфере модернизации образования направлена на его «рыночное» разделение. Подавляющее большинство выпускников обречено быть клерками, явное меньшинство, в основном из своих, плюс те, кто особо талантлив, составляет резерв топ-менеджеров. Дело не в названии университета, а в интересе к тебе, очень редко зависящим от тебя.

Расцвет рынка и его инфраструктуры обусловлены рождением массового производства. На первом уровне массового производства рынок был максимально регламентирован задачей развернуть реализацию товара в масштабах производства, чтобы воспроизводство было 


\begin{tabular}{|c|c|c|c|c|c|c|}
\hline \multirow{4}{*}{ Impact Factor: } & ISRA (India) & $=3.117$ & SIS (USA) & $=0.912$ & ICV (Poland) & $=6.630$ \\
\hline & ISI (Dubai, UAE & $=0.829$ & РИНЦ (Russia) & $=0.156$ & PIF (India) & $=1.940$ \\
\hline & GIF (Australia) & $=0.564$ & ESJI (KZ) & $=8.716$ & IBI (India) & $=4.260$ \\
\hline & JIF & $=1.500$ & SJIF (Morocco) & $=5.667$ & OAJI (USA) & $=0.350$ \\
\hline
\end{tabular}

динамичным. Над всем доминировала потребность производства в оборотных средствах, так как преимущество массового производства заключается в возможности сократить затраты, снизив тем самым себестоимость и повысив конкурентоспособность товара. Ключевым фактором сделалось время реализации товара. «Время - деньги». Массовое производство породило торговый принцип: потребитель не может не найти то, что ищет! Универсальные мега магазины предлагали практически весь ассортиментный ряд товара во всем его возможном разнообразии, в том числе и ценовом. Вскоре прояснилось, что отсутствие определенности сопряжено с высокими затратами сырья, энергии, содержания помещений, большим количеством нереализованной продукции, особенно лимитированной временем годности. Рынок со своей функцией не справился, как планировалось. Произошло важное событие, не получившее заслуженной оценки, возможно не хотели снизить репутационный рейтинг рынка. Производственники «пошли в народ» - изучать спрос с учетом социальной стратификации. Дело это хлопотное, достигаемая определенность не столь точна, как хотелось, но даже на условном уровне она служит основанием ориентации для планирования производства.

Б.С. Алешин с коллегами так характеризуют новый подход, получивший название «lean production» (щадящее, или рачительное производство): «Данный тип производства принципиально меняет саму цель производственного процесса. При этом традиционная задача изготовления большого числа однотипных изделий, отвечающих требованиям нормативной документации, из которых потребитель должен выбрать наиболее подходящее для него, заменяется задачей изготовления именно такого изделия, какое нужно данному потребителю и именно в требуемом объеме и в определенное время» $[4,7]$. Оценку перехода массового производства на новую ступень - обретения рациональности Б.С. Алешин и его соавторы явно идеализируют. Туфелька пришлась впору и ко времени Золушке в сказке, и то потому, что была второй ее туфелькой, тем не менее, маркетинговые исследования действительно существенно значимы для всех субъектов. Производители сокращают расходы, потребители получают более надежные гарантии приобрести искомый товар, посредники теряют прежнюю свободу манипулировать товарами и ценами. Но и увлекаться оценкой трансформации не уместно. Рынок за трехсотлетнюю историю развития промышленного производства наработал защитно-компенсаторный механизм от «наезда» и снизу - производителей, и сверху - правителей, самое же печальное, что рынок посредством лоббистов врос во власть, закрепил свои интересы в формулировках законов, их толковании. Второй опорой его сделались массмедиа, идущие без раздумий на любое нарушение регламентных лимитов на коммерческую рекламу, занимающиеся рекламой и «по белому» и «по черному» - во вне рекламное время.

Информационная работа рынка универсальна. Она включена в суть функционирования рынка и изменялась в течение всей истории рынка. Не менее очевидно и то, что рыночная информация развивалась подчас быстрее базовой части рынка, сформировавшись в отдельный сегмент рыночной реальности, что имеет своей основной причиной усиление конкуренции между производителями - товаров становилось на рынке все больше, росло и количество производителей. Рынок сам со временем сделался субъектом конкурентной борьбы, активно вовлекая рекламу и средства ее распространения.

Качественный товар, удовлетворяющий насущные запросы потребителя, в рекламе не нуждается. Рекламой на рынке была фамилия производителя, в России и в Европе признанные производители прибавляли к эмблеме своей торговли знак «поставщик двора» государственного правителя. Торговля была частью производства и осуществлялась под контролем хозяина. Взять, к примеру, Ивановскую мануфактуру, булочные-пекарни Филиппова в Москве, ювелирное дело К. Фаберже. Рекламой была оценка потребителя, кстати, идеалом рекламы как объективноинформационной деятельности и должна быть оценка товара общественным мнением. Сегодня об идеальном критерии рекламной практики не пишут и не говорят. Рекламу не просто отделили от информационного потока, построенного на объективных данных, сделали чисто коммерческим мероприятием, определив ее качество узко, прагматически в интересах продавца. Продавец вытеснил производителя на второй план. Что же касается покупателя, то в бушующем море рекламы он сродни изображенным И. Айвазовским людям на картине «Девятый вал», привязанным к обломкам мачты и надеющимся на помощь Бога. Лучший девиз рекламы - «Не обманешь - не продашь!» Исходя из «качественного анализа» рекламы, мы ввели понятие «рекламное качество», противопоставив его реальному качеству \{3].

«Реальное качество» в свою очередь также представляется непростой проблемой. В международных документах с целью достижения консенсуса понятие «качество» сознательно упрощают, определяя либо, как совокупность 


\begin{tabular}{|c|c|c|c|c|c|c|}
\hline \multirow{4}{*}{ Impact Factor: } & ISRA (India) & $=3.117$ & SIS (USA) & $=0.912$ & ICV (Poland) & $=6.630$ \\
\hline & ISI (Dubai, UAE & $=0.829$ & РИНЦ (Russia) & $=0.156$ & PIF (India) & $=1.940$ \\
\hline & GIF (Australia) & $=0.564$ & ESJI (KZ) & $=8.716$ & IBI (India) & $=4.260$ \\
\hline & JIF & $=1.500$ & SJIF (Morocco) & $=5.667$ & OAJI (USA) & $=0.350$ \\
\hline
\end{tabular}

специфических свойств предмета, услуги; либо, как высокий уровень способности удовлетворить потребности пользователя. Отсюда и стремление формализовать качество, довести его до количественных характеристик, чтобы в конце процесса получить техническую задачу.
Множественность представления качества является условием манипулирования качеством, высшей демонстрацией чего служит «работа» с качеством рекламных дел мастеров.

Качество товара проще представить в виде треугольника (рисунок 1):

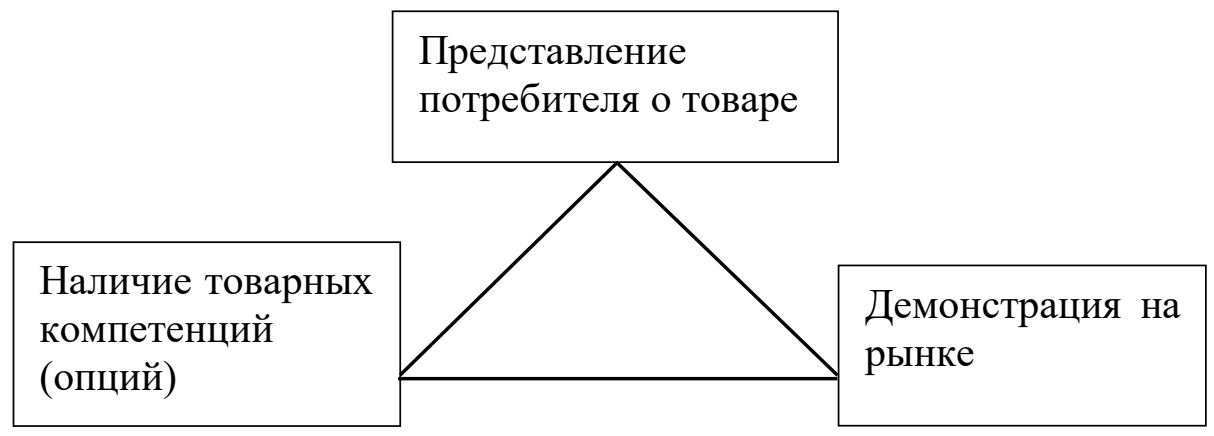

Рис 1. Архитектура признаков качества товара

Производство имеет смысл только как способ удовлетворения потребностей пользователя, следовательно, характеристика качества товара своего пика достигает в осознании именно потребителя, хотя объективность качества раскрывается производителем как специалистом. В былые времена цехового и мануфактурного производства проблема взаимопонимания и двустороннего удовлетворения упиралась исключительно в высокую стоимость производства. Часы во времена Гюйгенса творца маятникового механизма были доступны только очень богатым покупателям. Гюйгенс сделанные часы преподнес королю Франции. Людовик поинтересовался: как долго они послужат? Гюйгенс ответил: они с постоянной степенью точности удовлетворят Ваших потомков. Металлическая посуда рассчитывалась на поколения. Товар не надо было демонстрировать, ассортимент также был ограничен. Отношения производителя и потребителя, как правило (когда речь шла о товаре длительного пользования), оказывались непосредственными, информация была объективно данной, гарантированной производителем и данностью товара.

Реклама почувствовала свободу и от объективности качества и от ответственности за реализацию рекламируемого товара, когда рыночная информация потеряла непосредственную связь со своей предметной базой, перестала быть эссенциальной, перейдя на феноменолистический уровень - победило искусство «подать» товар. Любопытно проследить характер эволюции изобразительного искусства и искусства рекламной деятельности. Реализм в живописи на стыке XIX и XX веков уступил в популярности импрессионизму. Если художник-реалист стремился воссоздать предметную реальность в контексте человеческих эстетических чувств - пейзаж призван был показать красоту и силу природы, портрет раскрыть дух личности, опираясь на своеобразие изображаемого предмета, то импрессионисты своим предметом сделали игру света, создав новые технологии в живописи. Реальность изображаемого предмета они сохранили, его легко увидеть, но зритель видит предмет через взаимодействия со светом, действие которого передается новаторской техникой показа. С импрессионизмом появилось новое понятие в живописи - «пленэр».

Превращение информации похоже на эволюцию живописи, а реклама соразмерна с тем подходом к предмету, что вызвало к жизни искусство пленэра. Товар реклама исключить не может, элементы, свойственные рекламируемому товару, должны обязательно присутствовать в рекламе подобно предмету у импрессионистов, но как изобразить товар? Это уже принадлежит творцу рекламного продукта, рынок массового производства «потребительского» общества, практически не лимитирует свободу рекламной фантазии. Разница в виде риска. Импрессионист рисковал сам - мог остаться без покупателя и обанкротиться, рекламщик, в худшем случае, утратит на время какую-то часть доверия к своей компетентности.

Информационное начало организации рыночных отношений наглядно показала 3. Ножникова - историк культуры, собрав в своей монографии «Загадочная Московия» записки западных послов, побывавших на Руси в XVXVII столетиях [4]. Подавляющее большинство европейцев, посетивших Московию с 


\begin{tabular}{|c|c|c|c|c|c|c|}
\hline \multirow{4}{*}{ Impact Factor: } & ISRA (India) & $=3.117$ & SIS (USA) & $=0.912$ & ICV (Poland) & $=6.630$ \\
\hline & ISI (Dubai, UAE & $=0.829$ & РИНЦ (Russia & $=0.156$ & PIF (India) & $=1.940$ \\
\hline & GIF (Australia) & $=0.564$ & ESJI (KZ) & $=8.716$ & IBI (India) & $=4.260$ \\
\hline & JIF & $=1.500$ & SJIF (Morocco & $=5.667$ & OAJI (USA) & $=0.350$ \\
\hline
\end{tabular}

официальными визитами в составе посольств, были удивлены бытовой культурой, строительством, порядком и ... ценами на рынках. Многие сколотили свое состояние, вернувшись домой, на разницах цен купленных товаров на Руси и проданных на родине. Тогда информация о качестве российских товаров и реальной их цене была строго объективной, как и положено быть информации, ибо получали ее, что называется, из «первых рук» - от купцов или производителей. И те, и другие действовали в пределах установленного властью регламента под надзором царских приказов. Опираясь на документальные источники (П. Петрея, П. Аллепского, И.-Ф. Кильбургера и др.), 3. Ножникова заключает: «Интереснее всего многим иностранцам казались рынки. На рынках было на что посмотреть (т.е. товар сам себя рекламировал лучше, чем любая заказная реклама - Ю. М.)...

В прогулках по рынку можно было удачно совместить важное дело изучения состояния торговли в Московии, ... прицениться к будущим покупкам, которые, как подарки родственникам и друзьям, следует купить перед обратной дорогой, и - едва ли не главное - подивиться на чудеса за чудесами, как назвал московский рынок Айрман (помощник шведского посла - Ю. М.) [6]. Рынки в Москве и Архангельске работали в качестве рекламы развития самой Московии, были ее визитной карточкой для европейцев, плохо знавших Россию. Весьма маловероятно, что нынешние европейцы от российских рынков испытали те же чувства, с которыми их предки уходили с рынка. В Средней Азии есть поговорка: «Сколько ни говори халва, халва, халва, во рту сладко не станет». Она отлично характеризует наших политиков-либералов, утверждающих о рыночных достижениях РФ. Остается добавить к сказанному, что рынок, будучи явлением экономическим, отражает одновременно и политическую реальность. Рынок можно отпустить в свободное плавание, либо ввести за ним политический контроль в социальном спектре интересов, он, как наша национальная игрушка «неваляшка», останется показателем качества политического управления экономикой. И реклама здесь исполняет ту же функцию, что концертмейстер в симфоническом оркестре - настраивает звучание. Нормальный рынок, то есть действительно свободно и равноправно организованная торговля вне зависимости от размеров и положения продавца, с необходимостью требует информационного обеспечения. Все иное надстраивается над объективностью информации и призвано объективно - облагородить, окультурить исходный объективный информационный продукт.
В 1950-1970-е годы в торговле напрямую без посредников

сельхозпредприятия, участвовали промышленные предприятия, ориентированные на производство товаров массового производства. Повсюду были их торговые точки - палатки, магазины, автолавки и т.п. Единственным посредником был Коопторг, заинтересованный в проценте реализации не менее, чем в проценте прибыли, и скупавший качественный товар. Вся реклама заключалась в красиво оформленной вывеске, сообщающей адрес производителя, чтобы покупатель мог сориентироваться и определиться с выбором на перспективу. Отсутствие посредников (и в их числе «рекламщиков») заметно сокращало издержки производства и торговли, давало возможность снижать цены, делать товар массово доступным. На «колхозных» рынках, в магазинах коопторга очередей действительно не формировалось, исключением была реализация заслужившей доверие покупателей продукции промышленных предприятий - мебели, бытовой техники, одежды, обуви. Однако покупателей в отличие от современных супермаркетов оказывалось существенно больше. Низкий показатель инфляции за 2016 год демонстрирует ценовой предел. Цены сравнимы со знаменитыми «восьми тысячниками» Гималаев. «Восхождение» по силам не массовому покупателю с его ограниченной покупательской способностью, а отдельным группам, число которых также сокращается. Рекламный разумный потенциал истощается, а вместе с ценностью рекламы падает и удельный вес «спрятанной» за внешний антураж объективности информации. Наступает переломный момент, когда истинное качество рекламируемого товара подменяется стремлением любым способом придать ему привлекательность. На первый план, вместо объективности информации, выступает образ, качеством которого становится привлекательность.

«Привлекательность» из рекламной категории трансформируется в экономическую, точнее, - рыночный брэнд. Теоретически и даже методологически «привлекательность» относится к «сквозным» понятиям, характеризующим деятельность и ее продукцию. Вряд ли найдутся противники данного утверждения. Суть рассмотрения «привлекательности» в свете нашей проблематики не в определении «привлекательности» как таковой, а в конкретноисторическом ее проявлении. Деятельность способ реализации идеи, вне практической деятельности идея не выйдет за рамки элемента сознания, остается знанием и вероятнее всего потеряет через какое-то время значение. Актуальность, между тем, заложена не в самой 


\begin{tabular}{|c|c|c|c|c|c|c|}
\hline \multirow{4}{*}{ Impact Factor: } & ISRA (India) & $=3.117$ & SIS (USA) & $=0.912$ & ICV (Poland & $=6.630$ \\
\hline & ISI (Dubai, UAE & $=0.829$ & РИНЦ (Russia & $=0.156$ & PIF (India) & $=1.940$ \\
\hline & GIF (Australia) & $=0.564$ & ESJI (KZ) & $=8.716$ & IBI (India) & $=4.260$ \\
\hline & JIF & $=1.500$ & SJIF (Morocce & $=5.667$ & OAJI (USA) & $=0.350$ \\
\hline
\end{tabular}

деятельности, а в способе реализации замысла, способ же осуществления деятельности регламентирован пространственно-временными координатами, раскрывающими и ограничивающими актуальность способа действия. История складывается из актуальных исторических периодов - актуальных историй. Историческим явление, не зависимо от его природы - материальной или идеальной, становится не тогда, когда свершается, а только тогда, когда включается в историческую цепь событий. В диалектике общественное развитие поэтому описывается парой категорий «историческое-логическое», причем исторические явления могут «выпадать» из логики исторического процесса, что закономерно. Иначе развитие невольно заставило бы задуматься о Божественном сотворении общественной истории.

«Привлекательность» в широком контексте всегда стимулировала деятельность. В новейшей истории это понятие обрело новый смысл и соответственно новое значение. Оно оказалось в центре экономических противоречий на рынке. Его активно эксплуатируют в своих интересах все те, для кого рынок - основной источник спекуляций, они пойдут на «все тяжкие». В нем видят спасение потребителей те, кто сохранил честь профессионала-производителя.

Возникает вопрос: почему же столь устойчиво положение на рынке спекулянтов? Вопрос распадается на две части. Первая часть, за чей счет они имеют свою «маржу»? Ответ простой - их кормят производители и потребители, разумеется, не по доброй воле, вынужденно, подчиняясь закономерному порядку. Вторая часть, - почему так прописаны законы и что предпринимает власть на всех своих уровнях, чтобы быть властью народа демократией. На этом вопросе нам придется прекратить спрашивать. Ответ подскажет статистика. В количественном выражении, по сравнению с советским периодом, власть существенно укрепилась путем разветвления, увеличения от двух до трех раз числа своих работников, финансового наращивания обеспечения их благополучия и срастания с легальным маркетинговым бизнесом. Казалось бы шансов «привлекательность» обратить в интересах производства и потребления мало. Так оно и есть, но объективно они существуют.

Попытаемся подойти к решению проблемы системно и комплексно. Распространенные в современном научном познании системный и комплексный подходы удачно сочетаются между собою, давая возможность взглянуть на предмет исследования в двух базовых проекциях: извне (со стороны) и изнутри. При комплексном подходе к планированию производства требуется проанализировать все имеющиеся грани функционирования предмета, чтобы достигнуть не просто предельного значения объективности знания, но и получить «объемность» знания о предмете, исключить возможность упущения каких-либо существенных его проявлений. Мы нередко прикрываемся случайностью. Происходит это обычно тогда, когда забываем происхождение случайности. Случайность рождается на пересечении необходимостей. Профилактика нежелательных случайных событий опирается именно на активное вовлечение в процесс познания и управления комплексного подхода.

Системный подход открывает нам внутренние тайны и дает «ключи» к управлению самим предметом. В XX веке понятие «система» встало в ряд основных методологических понятий философии науки. «Система, множество элементов, находящихся в отношениях и связях друг с другом, которое образует определенную целостность, единство» [7, с. 324]. Системный характер построения знания (или явления действительности) определяется следующим образом: объект анализа условно разделяется на составляющие, если сумма свойств всех частей системы не совпадает с суммой свойств самой системы, то перед нами находится именно система. Отношения частей системы вызывают синергетические эффекты, что и является причиной расхождения значений сумм свойств.

Система также отличается наличием особого фактора формирующего систему, его определяют как системообразующий. Системообразующие факторы могут быть монистичными - так, к примеру, вырастает кристалл, на таком же факторе Д.И. Менделеев выстроил Периодическую систему химических элементов, первым поняв значение различия атомных весов, либо дуалистичными. Долгое время не могли расшифровать системную основу наследственной функции ДНК, пока не пришла мысль раздвоить ее цепь. Создается впечатление, что цепь ДНК рождается отношениями двух оснований, функционально взаимообусловленных - элемента и свойства. Они как бы «привязаны» одно к другому, благодаря чему и возникает двойная спираль ДНК. К. Маркс, как уже было отмечено, раскрыл системное построение товара, представив товар как отчуждаемый продукт, имеющий меновую и потребительскую стоимость. Системный статус товара определил порядок отношений на товарном рынке, но не сразу. А. Смит не понял, почему повышение производительности труда не сопровождается увеличением зарплаты рабочих.

Политэкономия, как наука, проникает в логику системных отношений, определяющих бытие ранка, но не его реальность. Реальность 


\begin{tabular}{|c|c|c|c|c|c|c|}
\hline \multirow{4}{*}{ Impact Factor: } & ISRA (India) & $=3.117$ & SIS (USA) & $=0.912$ & ICV (Poland) & $=6.630$ \\
\hline & ISI (Dubai, UAE & $=0.829$ & РИНЦ (Russia & $=0.156$ & PIF (India) & $=1.940$ \\
\hline & GIF (Australia) & $=0.564$ & ESJI (KZ) & $=8.716$ & IBI (India) & $=4.260$ \\
\hline & JIF & $=1.500$ & SJIF (Morocco & $=5.667$ & OAJI (USA) & $=0.350$ \\
\hline
\end{tabular}

рынка - это уже иная система, отличная от системы бытия товарного производства. Рынок обусловлен социально-политической реальностью, поэтому на рынке и происходит то, что не входит в логику товарного производства, однако является активно действующей инфраструктурой. Формальная логика проста: исторически необходимо взаимное удовлетворение интересов производителя и потребителя. Только тогда история будет тоже «разумной историей» «разумного человека». Реальная история внешне представляется иррациональной. На самом деле и реальная история разумна, путь к разумности исторического движения подобен движению железнодорожного состава, выбирающегося с большой станции со множеством путей и стрелок, на главный путь.

Системообразующим фактором построения концепции привлекательности товара, на наш взгляд, должна быть способность товара вызывать актуальность потребности в нем. Покупателя мало заинтересовать, интересу необходимо придать форму актуальной потребности в предлагаемом товаре. Потребность - важнейший показатель психофизиологического настроения личности. «Потребности - нужда живого организма в чемто, что необходимо для его жизни и развития... потребности создают мотивы поведения» [8, с. 246]. В научной литературе встречается несколько попыток классифицировать человеческие потребности. К сожалению ни одна из тех, что нам известны, не представляется системной. Чаще всего упоминается «Пирамида потребностей» А. Маслоу, изображенная на следующем рисунке 2

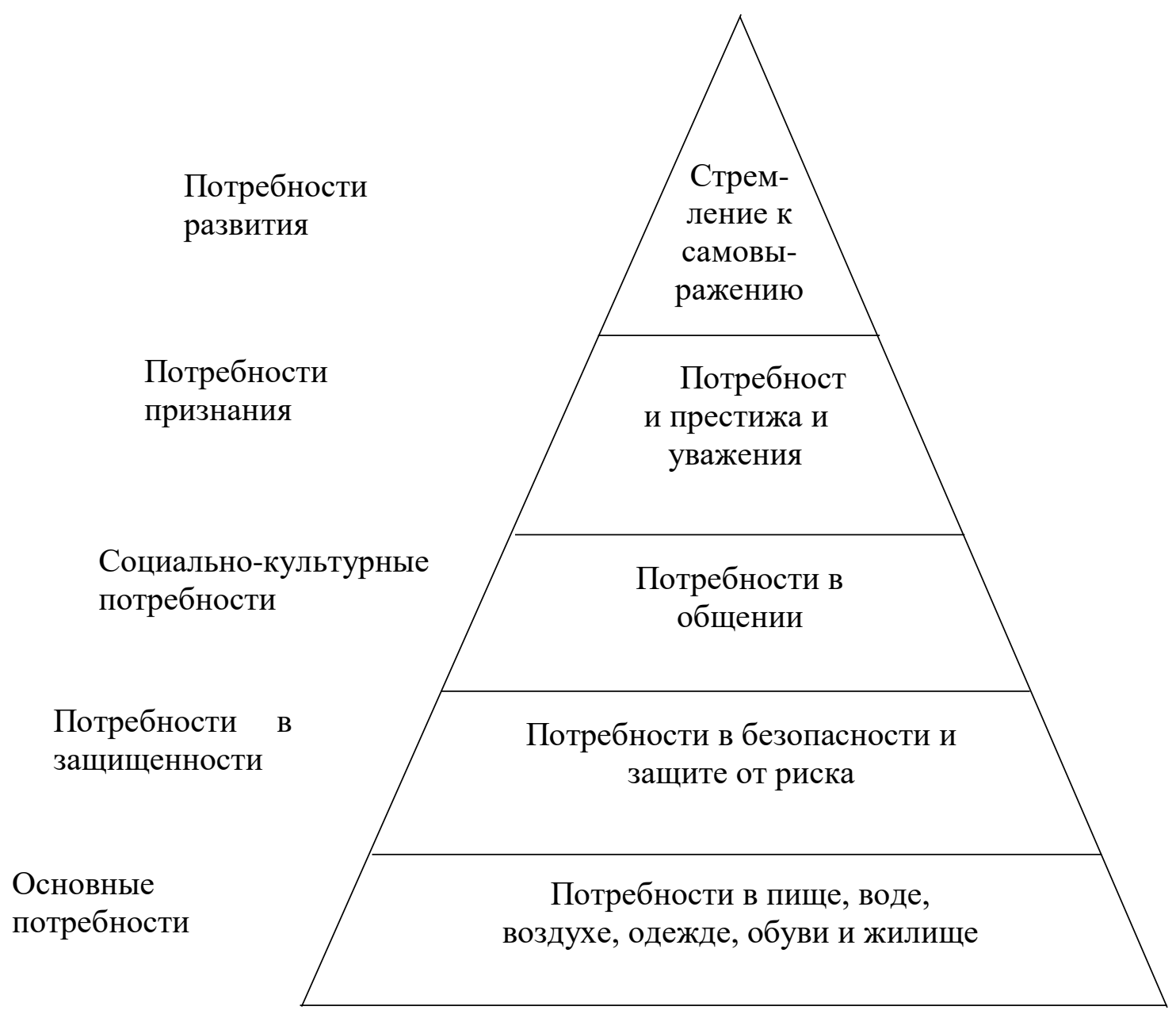

Рис. 2. Пирамида потребностей (по А. Маслоу)

А. Маслоу считал, что на основе анализа степени удовлетворенности приведенных потребностей, можно выстроить эффективное управление компанией. Отдельные авторы, в частности, Б.С. Алешин, Л.Н. Александровская, В.И. Круглов, А.М. Шолом подтверждают, что «за время ее использования был сделан ряд уточнений», и в целом она «стала важнейшим 


\begin{tabular}{|c|c|c|c|c|c|c|}
\hline \multirow{4}{*}{ Impact Factor: } & ISRA (India) & $=3.117$ & SIS (USA) & $=0.912$ & ICV (Poland) & $=6.630$ \\
\hline & ISI (Dubai, UAE & $=0.829$ & РИНЦ (Russia & $=0.156$ & PIF (India) & $=1.940$ \\
\hline & GIF (Australia) & $=0.564$ & ESJI (KZ) & $=8.716$ & IBI (India) & $=4.260$ \\
\hline & JIF & $=1.500$ & SJIF (Morocco & $=5.667$ & OAJI (USA) & $=0.350$ \\
\hline
\end{tabular}

инструментом деятельности менеджера» [4, с. 19].

В нашем понимании «Пирамида Маслоу» интересна в качестве общего подхода к комплектации потребностей. В ней отсутствуют культурные - нравственно-эстетические потребности, потребности в знаниях и навыках, в физическом развитии, здоровье. Физиологические потребности традиционно заложены в основание конструкции, что явно ограничивает их функционально. Систему человеческих потребностей следует выстраивать на принципе дуалистичности природы человека. Дуализм человеческой натуры так или иначе проявляется не только в отношении базиса и надстройки, но и функционирует на всех уровнях личной и общественной жизни индивида. К тому же нужно подчеркнуть социально-временную и социально-пространственную конкретность потребностей, значение их актуальности.

В плане анализа проблемы «привлекательности» товара особое значение имеет генезис потребностей покупателя. С точки зрения генезиса потребности человека исследуются в основном в двух наиболее общих ракурсах, обусловленных видовой спецификой биологическом и социальном. Различают врожденные потребности и приобретенные в социокультурной истории. Нам представляется это недостаточным, так как в развитии потребностей не отражен фактор времени и социальная конкретика. Важно разделять потребности на потенциальные и актуальные. Актуальные потребности инициируются внешними факторами жизнедеятельности, они в условиях рыночной экономики и ее массового этапа весьма значимы в свете работы над бизнес перспективой.

Современный покупатель со стороны выглядит «продвинутым», однако его осведомленность явно дилетантского типа, особенно у молодых, старающихся показать себя знающими, не понимая, что поводырем его осведомленности выступает, за редким исключением, все та же реклама, индуцирующая знания в направлении, выгодном продавцу. Потребитель оказывается на поводке у рыночных интересов. Потребителя необходимо воспитывать и рынок с удовольствием этим занимается, меньше всего, естественно, думая о потребностях покупателей. Рынку важно пробудить потребность и активировать ее якобы в двухсторонних интересах. Интересы, возможно, и обоюдные, только до паритета здесь далеко.

Мы не оцениваем рынок в общем и целом. Рынок разнообразен, на нем работают и нравственно ответственные продавцы, к несчастью не они определяют состояние и динамику рыночной политики. На известной картине И. Шишкина «Утро в сосновом бору» изображены три медведя по самому центру полотна. Именно на них падает взгляд посетителя Третьяковской галереи, однако художник в названии произведения указывает на утренний лес, вписывая в его тишину пробуждение мишек. Рынок также вписан в общую картину противоречий мирового производства, нацеленного на выигрыш производителя и посредника. Делиться с потребителем они готовы, но не как с равноправным партнером. «Третий» обречен оплачивать интересы первых двух.

Формально такое соотношение объективно необходимое. Производству требуется развитие, нужна прибыль. Прибыль в основном обеспечивается рынком. Продавец так же своего рода работник и по праву имеет свою долю. Не работником на рынке оказывается только покупатель, даже полиция и та на службе. Потребителю и продвигать своим кошельком производственный прогресс - производство ведь рыночное. Рынок уподоблен управляемому хаосу. В этом суть либеральной экономической политики. В тех странах, где управление отработано веками, хаос менее заметен. У нас попрежнему работает принцип, сформулированный B.C. Черномырдиным. Есть лишь сомнения в отношении первой его части - желание «сделать как лучше» почти пропало. В связи с вышеизложенными размышлениями возникает вопрос: можно ли изменить ситуацию в интересах потребителя? Можно, изменив политику в отношении производства, но прежде о частном.

Понятие «привлекательность», используемое для характеристики товара, корректно рассматривать в двух редакциях - объективной и субъективно-объективной. Привлекательный товар объективно должен быть таковым качественным, чтобы исключить обман. Что касается соответствия цены качеству, то хорошо известно как на этом спекулируют. Вместе с тем понятно и то, что качественный товар удовольствие не из дешевых. Качественность товара не означает автоматически ограниченность возможности его приобрести. Качество имеет несколько уровней качественных состояний. Необходимо стремиться обеспечить ассортимент качественности, чтобы расширить покупательские возможности за счет диапазона цен.

Качество товара - базово объективный параметр привлекательности. Над качеством надстраивается то, что мы определяем «субъективно-объективной» характеристикой привлекательности товара. Название подчеркивает двойственность природы образующих надстройку свойств 


\begin{tabular}{|c|c|c|c|c|c|c|}
\hline \multirow{4}{*}{ Impact Factor: } & ISRA (India) & $=3.117$ & SIS (USA) & $=0.912$ & ICV (Poland) & $=6.630$ \\
\hline & ISI (Dubai, UAE & $=0.829$ & РИНЦ (Russia) & $=0.156$ & PIF (India) & $=1.940$ \\
\hline & GIF (Australia) & $=0.564$ & ESJI (KZ) & $=8.716$ & IBI (India) & $=4.260$ \\
\hline & JIF & $=1.500$ & SJIF (Morocco) & $=5.667$ & OAJI (USA) & $=0.350$ \\
\hline
\end{tabular}

привлекательности. Их целесообразно для наглядности изобразить схематически (рисунок 3).

\section{Удовлетворение актуальной потребности}

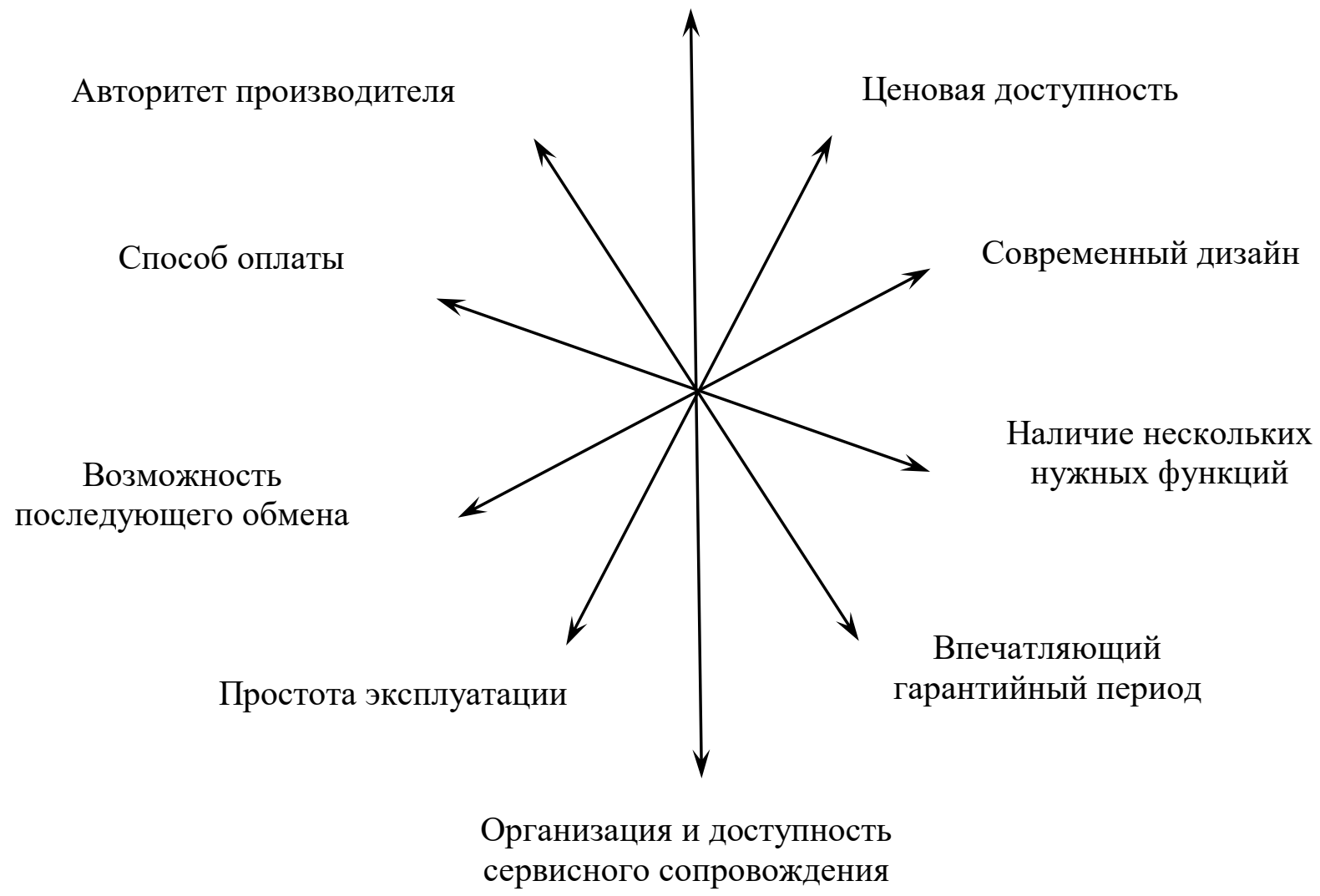

Рис. 3. Архитектура факторов «привлекательности товара»

Понятие «привлекательность товара» специально не исследовалось. Оно существовало в форме идеи, преимущественно не в интересах потребителя, а как задача рекламной работы. Поэтому привлекательность была более фантомной, чем реальной. Реклама стремилась абсолютизировать объективные данные, фальсифицируя действительные возможности товара, представляя его эксклюзивным продуктом, мимо которого пройти нельзя.

Настало время обстоятельно и всесторонне углубиться в данную проблему, проанализировать признаки привлекательности. Пионерские исследования в интересах потребителя были осуществлены в Японии, именно с ними (но не только) связывают успехи японской промышленности в 1980-90-е годы. «Японцы», пишет Б.С. Алешин, первыми осознали важность лучшего понимания нужд потребителя (клиента) и необходимость системного подхода к анализу его ожиданий для выявления степени их влияния на технические характеристики создаваемого продукта и обеспечения в конечном итоге максимальной ценности продукта для потребителя» [4, с. 83]. Японские экономисты вычислили, что создавая привлекательность товара, производители активируют свои резервы и продвигают производство вперед, т.е. «привлекательность», в ее истинном смысле, обоюдовыгодна и не надо 


\begin{tabular}{|c|c|c|c|c|c|c|}
\hline \multirow{4}{*}{ Impact Factor: } & ISRA (India) & $=3.117$ & SIS (USA) & $=0.912$ & ICV (Poland) & $=6.630$ \\
\hline & ISI (Dubai, UAE & $=0.829$ & РИНЦ (Russia & $=0.156$ & PIF (India) & $=1.940$ \\
\hline & GIF (Australia) & $=0.564$ & ESJI (KZ) & $=8.716$ & IBI (India) & $=4.260$ \\
\hline & JIF & $=1.500$ & SJIF (Morocco & $=5.667$ & OAJI (USA) & $=0.350$ \\
\hline
\end{tabular}

ни на производстве, ни на рынке дезориентировать потребителя.

В Японии, а не в Америке и Европе, впервые была дана оценка качественности привлекательности товара. Именно японские специалисты пересмотрели тезис о том, что работа над качеством привлекательного товара неизбежно приведет к повышению цены и нанесет непоправимый удар по исходной цели. Один из ведущих аналитиков И. Исикава, опровергая мнение скептиков, повсюду утверждал о безнравственности повышения цены при повышении качества продукции. Он пояснял, что получение более качественной продукции обусловлено, в первую очередь, сокращением издержек производства - уменьшением дефектности, совершенствованием организации производства, технологической дисциплины. Все перечисленные операции не требуют существенного увеличения расходов и сопряжены со снижением в конечном счете себестоимости, следовательно и цены товара. Исключением служит случай, когда более качественный товар производится как продукт «принципиально нового технического уровня» [7].

Эффективное экономическое управление в условиях развитого и ответственного производства опирается на «три золотые истины», извлеченные из многолетней практики успешного менеджмента:

- экономическое долголетие и авторитет на рынке связаны с заботой о качестве и о цене качественного продукта;

- алчность - это не только безнравственно, но и очень неэкономично, так как свидетельствует о невежестве менеджмента, который всегда дорого обходится производству;

- люди в качестве потребителей и производителей - золотой фонд развития производства.

Хочешь заработать профессиональный авторитет, занимайся организацией производства нужного, качественного и доступного потребителю с ограниченными покупательскими возможностями продукта. Тогда о сбыте можно будет думать, не нервничая, и не платить рекламщикам, рискуя оказаться у «разбитого корыта». Популярный в средине прошлого столетия канадский писатель С.Б. Ликок объяснял: «О рекламе можно сказать, что это наука затемнять рассудок человека до тех пор, пока ты не получишь от него деньги» [8-10]. «Рекламщиков» сложно судить. Не они себя придумали, их произвели на свет те, кого простая, но объективная информация, не спасала. Не имея возможности добиться признательности потребителя, не востребованные «по белому» производители, искали выход на покупателя через посредника, готового работать «почерному», а главное, отложить в сторону высокие нравственные принципы.

Японский менталитет, пережив кризис позорного поражения во Второй Мировой войне, значительные человеческие потери, тем не менее, помог за четверть века осознать путь спасения в качестве иной организации производства. Слава Богу, в России дело до войны не дошло, не было позорной капитуляции, но был и остается развал в экономике и, что особо беспокоит, - в сознании. Не видно признаков осознания производителями профессиональной и социальной ответственности. Декорации 1990-х заменили декорациями «нулевых». Малиновые пиджаки и золотые цепи сменили на костюмы от кутюрье. Поменьше стали стрелять, однако «новое мышление», о котором так мечтал М.С. Горбачев, не сложилось. Не потому, что не способны думать как положено homo sapiens, а по причине безнравственности и невежества многомиллионного менеджмента. Иногда складывается впечатление, что законодателями политэкономической моды по-прежнему остаются маркетологи и шоумены. К «лампочкам Ильича» добавился тусклый холодный свет назначенных «звезд». Светлее не стало, однако холодеешь, когда кризисные явления становятся хроническими, из осовременивания модернизация переходит в тормоз развития.

По всему видно, что со «своими» новациями у нас пока не получается. Посмотрим на опыт других. В последнее время Президент и Правительство все больше подчеркивают значение связей с восточными соседями.

Концепцию «Всеобщего менеджмента качества (TQM)» позиционируют как экономическую теорию общества массового потребления. Согласимся, но отметим, что базовая ее часть построена на социальной философии. У истоков ТQМ оказались те же японцы в сотрудничестве с творчески мыслящими американцами. К. Исикава организовал в 1950-е годы JUSE - «Японский союз ученых и инженеров». Ему активно помогали Э. Деминг и Й. Джуран. Центральной целью JUSE стала разработка методологии экономической политики повышения качества промышленной продукции. Опираясь на опыт США и Европы, JUSE делал только свои первые шаги. Далее, не без влияния национального менталитета, разработчики пошли своим путем с акцентом не на контроль качества, а на потребителя - «потребитель всегда прав». Сменилась система отсчета с «руководителя» на «потребителя». Место «босса» занял «потребитель», рокировка потребовала изменить «саму систему достижения цели в новых условиях конкурентной борьбы на рынке». 


\begin{tabular}{|c|c|c|c|c|c|c|}
\hline \multirow{4}{*}{ Impact Factor: } & ISRA (India) & $=3.117$ & SIS (USA) & $=0.912$ & ICV (Poland) & $=6.630$ \\
\hline & ISI (Dubai, UAE & $=0.829$ & РИНЦ (Russia & $=0.156$ & PIF (India) & $=1.940$ \\
\hline & GIF (Australia) & $=0.564$ & ESJI (KZ) & $=8.716$ & IBI (India) & $=4.260$ \\
\hline & JIF & $=1.500$ & SJIF (Morocco & $=5.667$ & OAJI (USA) & $=0.350$ \\
\hline
\end{tabular}

Акцент на потребителя означает не только его главенствующую роль в деятельности системы, но и получение достоверной информации о нуждах и пожеланиях потребителя. Поэтому появляется необходимость в «контактном персонале», от которого зависит не только достоверность, поступаемой от потребителя информации, но и субъективный имидж компании в глазах потребителя. Сотрудников, занятых разработкой, производством и доставкой продукта в соответствии с новой парадигмой, следует рассматривать как персона поддержки удовлетворений требований потребителя. Они должны быть объединены и включены в систему, выполняющую главную цель - увеличение ценности продукта для потребителя и уменьшение его стоимости» [11]. Так определили суть новой парадигмы развития производства Б.С. Алешин с соавторами, а мы нашли у предшественников экономический праобраз понятия «привлекательности».

Первоначально оно выступало как тандем понятий «ценность» и «уменьшение цены». Сейчас мы можем с уверенностью назвать ту пору, когда на Руси массовому потребителю будет «жить хорошо», - тогда, когда сменится нынешняя парадигма - «урвать куш». Не скоро. Японцам способствовал национальный менталитет, европейцам - трехсотлетняя история шлифования отношений на рынке, американцам сытая жизнь без войн на территории. Чтобы наши производители и менеджеры продаж перевели экономическую стрелку на новую парадигму, у них должен быть приказ Диспетчера. Их психология - отдельные исключения, как первая ласточка, не меняют картины, прочнее стен Брестской крепости и рынок стоять готов до последнего. Наш рынок интересуется покупателем исключительно в качестве экономического субъекта, но не как человеком, личностью, земляком. Национальный колорит рынка давно не похож на национальный состав РФ. Цены на рынке устанавливаются не соотношением купли-продажи, их регулирует размер маржи босса. Если нам в ближайшей перспективе не внедрить TQM реально - не по бюрократическим отчетам, непонятно кого и что будет защищать доблестные перевооруженные ВКС, ВМФ и армия.

Где серьезные, системные исследования удовлетворенности продуктом российского покупателя. Между тем, индексация степени удовлетворенности позволяет количественно оценить вклад различных составляющих качество производства, а не оперировать средними значениями. Трудно отделаться от мысли, что официальная реакция на TQM служит прикрытием практической деятельности по блокированию внедрения этой системы в реальный процесс экономического движения. Дело в том, что TQM радикально меняет понимание ценности вклада всех участников производства продукта, четко определяя кто, что и как сделал. Наш производитель вряд ли созрел приветствовать подобный аудит.

Методологически разворот производителей и продавцов лицом к потребителю уже расписан по основным позициям, ничего не надо изобретать, вкладывать серьезные средства. В литературе присутствует пошаговый маршрут осмысления идеи настоящей гуманизации и демократизации производства, соответствующей строительству потребительского общества. Его можно найти даже в учебниках. Читаем «Акцент на потребителя заключается в следующем:

- процессы существуют, чтобы удовлетворять нужды людей и потребности общества;

- процессы полезны, если они добавляют ценность для людей и общества;

- желания и нужды различны во времени и пространстве (для разных наций и культур);

- процессы различны в различных культурах и у разных наций;

- потребности и процессы их удовлетворения могут быть смоделированы и отслежены с использованием статистического анализа;

- лучшая модель процесса удовлетворения потребностей общества должна быть принята руководством при непосредственном участии каждого члена общества» [4, с. 84].

Последнее положение сформулировано не совсем корректно в отношении «каждого члена общества». Столь тотальная задача скорее романтична, нежели реалистична. Для старта хватит и простого большинства потребителей. Затем начнется цепная реакция и с каждым шагом все будут ближе к результату.

Потребители различаются не только своими запросами и претензиями. У низ разный и социальный статус, их субъективность. Потребитель может быть личностью, социальной группой, производственным образованием. Поэтому в теории имеется классификация внешнего потребителя, в основу которой положен принцип «конечного звена» цепи производства. Потребительский статус подобен производственному. Так же, как и процесс производства, потребление предполагает несколько этапов подготовки конечного продукта. Потребителями могут быть и производители, но они представляют промежуточные звенья. Конечным потребителем является отдельно взятый человек. Человек начало общественной истории, ее главный 


\begin{tabular}{|c|c|c|c|c|c|c|}
\hline \multirow{4}{*}{ Impact Factor: } & ISRA (India) & $=3.117$ & SIS (USA) & $=0.912$ & ICV (Poland) & $=6.630$ \\
\hline & ISI (Dubai, UAE & $=0.829$ & РИНЦ (Russia) & $=0.156$ & PIF (India) & $=1.940$ \\
\hline & GIF (Australia) & $=0.564$ & ESJI (KZ) & $=8.716$ & IBI (India) & $=4.260$ \\
\hline & JIF & $=1.500$ & SJIF (Morocco) & $=5.667$ & OAJI (USA) & $=0.350$ \\
\hline
\end{tabular}

инструмент и цель социального прогресса. Можно ли поставить в ряд потребителей остальных субъектов? Естественно, но их потребление обусловлено жизнедеятельностью человека. К примеру, в исследовании космического пространства в первую очередь заинтересована наука. Она - непосредственный потребитель получаемого продукта, она же и заказчик и участник технического проекта. Космические аппараты - продукт научнопроизводственного взаимодействия. Производство развивает таким образом свою технологическую базу, следовательно и технологические новации бесспорно принадлежат к ряду продуктов. С научными исследованиями, как правило, кооперируются различные ведомства, получая свою долю продукта. Тем не менее, сколько бы мы ни продолжали отслеживать путь научноисследовательского продукта, конечным пунктом окажется человек - его здоровье, благополучие, безопасность, познавательные и практические интересы.

Выделяя конечный статус в потреблении человека, не следует абсолютизировать данный вывод. Маугли был «человеческим детенышем», чтобы стать человеком - социализировался, то есть вступил в структуру, создаваемую человеческим общением. Интересы отдельно взятого человека - потребителя - важны, но их нельзя изолированно рассматривать. Массовое производство, как бы «рачительно» оно ни было устроено, не способно работать на индивидуальность. Максимально его можно замкнуть на малую социальную группу.

Императив моды и техникотехнологических возможностей формируют конкретно-социальные и конкретно-исторические ограничения производства. Индивидуальность проявляется через групповую форму реальности. Только через социальную принадлежность - пол, возраст, покупательские возможности, психологический статус, воспитание, национальность, личность ориентируется на рынке потребления, имея при этом вполне достаточно свободы действия в рамках социальной обусловленности своих вкусов. Ктото делает свой выбор осознанно, другие подсознательно, третьи, сочетая рассудительность с коллективным бессознательным (К. Юнг).

Экономическая наука внешнего потребителя рассматривает как сочетание трех групп: конкретного конечного пользователя - личности; потребителя-посредника (перепродавца, дистрибьютера); коллективного унитарного предприятия. Для правильного определения экономических приоритетов требуется изучение потребительских интересов всех внешних потребителей. Значение потребительских предпочтений для производителя различно и зависит от статуса самой компании, ее производственной ориентации. Но проблемы «привлекательности» товара не избежать при всех раскладах.

«Фирма должна тщательно контролировать всю цепочку процесса взаимодействия поставщик - потребитель. Крупные фирмы практикуют анкетирование своих постоянных и потенциальных потребителей с периодичностью один раз в год. В анкеты включаются, как правило, не более семидесяти вопросов. Для корректировки своих целей в долгосрочном планировании один раз в три года производители рассылают более подробные анкеты, предназначенные для крупных потребителей выпускаемого продукта [4, с. 88].

Японский менталитет подсказал рефлексирующим менеджерам, что тот, кто рассчитывает на перспективу, не должен ограничиваться пониманием действующих потребителей. Конечный потребитель - член семьи, местной общины. За ним стоят будущие покупатели, пока не решившие для себя вопрос, что у кого приобретать. «Сарафанное радио» работает бесплатно и более продуктивно, чем реклама. Покупателя надо из абстрактного потребителя переводить в состояние «своего» человека, включать в систему партнерских отношений. Пока мысль о покупке, консолидируя потребность в товаре, зреет как желание, ей следует сообщить вектор движения к соответствующему производителю.

«Акцент на потребителя» свободно конвертируется в технико-экономическую задачу - придать своей продукции привлекательный вид. Такой товар не нуждается в рекламных издержках производства, напротив, помогает снизить в итоге себестоимость, сделать реальные «sale» и ускорить оборотное движение затраченных на производство средств. Б.С. Алешин правильно объясняет производителям, недоценивающим значение фактора привлекательности товара для потребителя, думающим лишь о том, как сократить производственные расходы: «Акцент на потребителя в решении всех вопросов позволяет поставщику каждый раз сверять свой курс в конкурентной борьбе по «компасу» потребителя, гарантируя себе справедливое вознаграждение и удовлетворяя одновременно ожидания потребителя относительно ценности продукта, его стоимости и времени поставки. Удовлетворенный потребитель не только возвращается к такому поставщику, но и вносит свой позитивный вклад в маркетинг этого предприятия посредством «передачи информации 


\begin{tabular}{|c|c|c|c|c|c|c|}
\hline \multirow{4}{*}{ Impact Factor: } & ISRA (India) & $=3.117$ & SIS (USA) & $=0.912$ & ICV (Poland) & $=6.630$ \\
\hline & ISI (Dubai, UAE & $=0.829$ & РИНЦ (Russia & $=0.156$ & PIF (India) & $=1.940$ \\
\hline & GIF (Australia) & $=0.564$ & ESJI (KZ) & $=8.716$ & IBI (India) & $=4.260$ \\
\hline & JIF & $=1.500$ & SJIF (Morocco & $=5.667$ & OAJI (USA) & $=0.350$ \\
\hline
\end{tabular}

по цепи», что влияет на общий имидж компании» $[4$, c. 89$]$.

Известный специалист в сфере управления и его коллеги напрасно пощадили чувства производителей, представив дело в позитивном ракурсе. Нашего производителя и продавца чаще нужно погружать в негативную перспективу, чтобы напугать, особенно работников «прилавка». Покупатель по информационной потребительской цепи способен и отвратиться от покупки проблемного товара и тогда у производителя откроется «болезнь №1» по Э. Демингу.

Производитель и конечный потребитель его товара разделены продолжением производства и рынком. Нужно свести это разделение к минимуму, чтобы было меньше опосредованности между двумя работниками тем, кто товар производит, и тем, кто на свои, честно заработанные средства, законно хочет купить то, что ему нравится и по справедливой цене. Решение этой проблемы находится в плоскости рынка. Производящее предприятие должно включить себя в рыночный процесс, организовав фирменный способ реализации продукта. Это позволит освободить рынок от фальсификата, снизить ценовую нагрузку на конечного потребителя, вести мониторинг продвижения товара, лучше и проще изучить спрос покупателя, ускорить получение оборотного капитала, эффективнее работать над качеством товара, учитывая пожелания потребителя.

В Японии, наряду с традиционным методом управления качеством Кайрио (Kairio), направленным на технические и технологические скачки - микрореволюции, под влиянием развития связей с потребителем, получил широкое распространение подход Кайзен (Kaizen). В отличие от «Кайрио», «Кайзен» не предполагает крупных инвестиций, он нацелен на мелкие улучшения качества продукта, однако выгодно выделяется тем, что рассчитан на вовлечение в процесс неограниченного числа специалистов -исследователей, конструкторов, ученых, и всех думающих, заинтересованных работников. Качественный эффект, добавляющий привлекательности товара и у потребителя, достигается путем сочетания большого количества мелких шагов с большим количеством желающих принять участие и способных работать на результат.

У американцев была схожая идея решения проблемы, они ее называли «тактикой сервелата». Колбасу типа сервелат толстыми кружками не принято резать - неудобно есть, поэтому отрезают тонкими пластиками, но итог тот же, что и в случае с мягкой колбасой. Японцы под впечатлением менталитетного императива, замечательно описанного журналистом международником В. Овчинниковым («Ветка сакуры»), выжимающие из продукта, идеи до конца, приспособили принцип сервелата к управлению развитием производства, в основном, для повышения привлекательности продукта. Кроме описанного эффекта, «Кайзен» консолидирует работников, убеждая их в том, насколько значим каждый из них, если он заинтересован в результате, формирует потребность повышать личное мастерство, развивает чувство профессиональной гордости.

Есть чему поучиться и у американцев, в частности их настырности, уверенности в себе и своих возможностях. У. Черчилль однажды сказал: «Вы всегда можете рассчитывать, что американцы все сделают правильно, после того как они перепробовали все остальные варианты». В 1990-е годы промышленность США имела серьезные проблемы со сбытом и развитием. Проанализировав результаты бизнеса, американцы определили три приоритета: потребительская удовлетворенность, необходимость снижения затрат на производство и времени на циклы.

Анализ ситуации заставил обратить внимание на важность комбинирования факторов повышения эффективности, особенно акцента на потребителя, реинжиниринга и информационной составляющей. «Массовый потребитель» вытеснил «массовое производство». Вот как известная пошивом джинсов американская фирма «Левис» вернула лидерские позиции производителя женских джинсов.

Опираясь на информационные технологии, «Левис» предложила покупательницам 2400 размеров разных цветов и стилей. Непосредственно в фирменном магазине, либо отделе определялась на основе джинсов со встроенными магнитными мерками, индивидуальность размеров, клерк по компьютеру передавал заказ на производство и без промедления покупательница получала то, о чем мечтала. Более мелкие фирмы вообще стали выходить прямо на потребителя, минуя посреднические магазины и склады, принимая покупателей в офисах с функцией реализации товара.

Понятие «привлекательность продукта» частично раскрывается в понятии «ценность продукта». В специальной литературе «ценность продукта» определяется как «совокупность ожидаемых потребителем параметров качества необходимого ему продукта и их значения, удовлетворяющие запросам потребителя» [12]. Развертку ценности продукта называют «деревом потребительской удовлетворенности».

Чтобы ценность товара вызвала потребительскую удовлетворенность, важно не 


\begin{tabular}{|c|c|c|c|c|c|c|}
\hline \multirow{4}{*}{ Impact Factor: } & ISRA (India) & $=3.117$ & SIS (USA) & $=0.912$ & ICV (Poland) & $=6.630$ \\
\hline & ISI (Dubai, UAE & $=0.829$ & РИНЦ (Russia & $=0.156$ & PIF (India) & $=1.940$ \\
\hline & GIF (Australia) & $=0.564$ & ESJI (KZ) & $=8.716$ & IBI (India) & $=4.260$ \\
\hline & JIF & $=1.500$ & SJIF (Morocco & $=5.667$ & OAJI (USA) & $=0.350$ \\
\hline
\end{tabular}

только быть озабоченным качеством товара, но и помнить, что сознание потребителя не является константой, оно движется, зреет. Выражение «клиент созрел» характеризует процесс взаимодействия производителя и потребителя. Потребитель в таком взаимодействии представлен психической деятельностью прежде всего. Источники психической готовности принять предложение производителя как совпадающее с собственным представлением о привлекательности товара неоднородны. Обычно к ним причисляют:

- авторитет производителя;

- информацию из источников, заслуживающих доверие;

- потребительскую

неформальное общение;
- наличие товара в прошлом опыте покупателя;

- актуальность данной покупки для покупателя.

Если психологически образ товара как привлекательный сформировался, то отношения из фазы абстрактной возможности переходят в реальную возможность. Следующий шаг трансформация реальной возможности в действительность приобретения понравившегося товара будет зависеть от соотношения затрат производителя и потребителя. Для первого, речь идет о соотношении себестоимости и цены, для второго - цены и качества продукта.

Й. Джуран подчеркивал особое место в структуре потребительских запросов качества услуг. Б.С. Алешин приводит расшифровку качеств услуги, способной заинтересовать потребителя в покупке (рисунок 4).

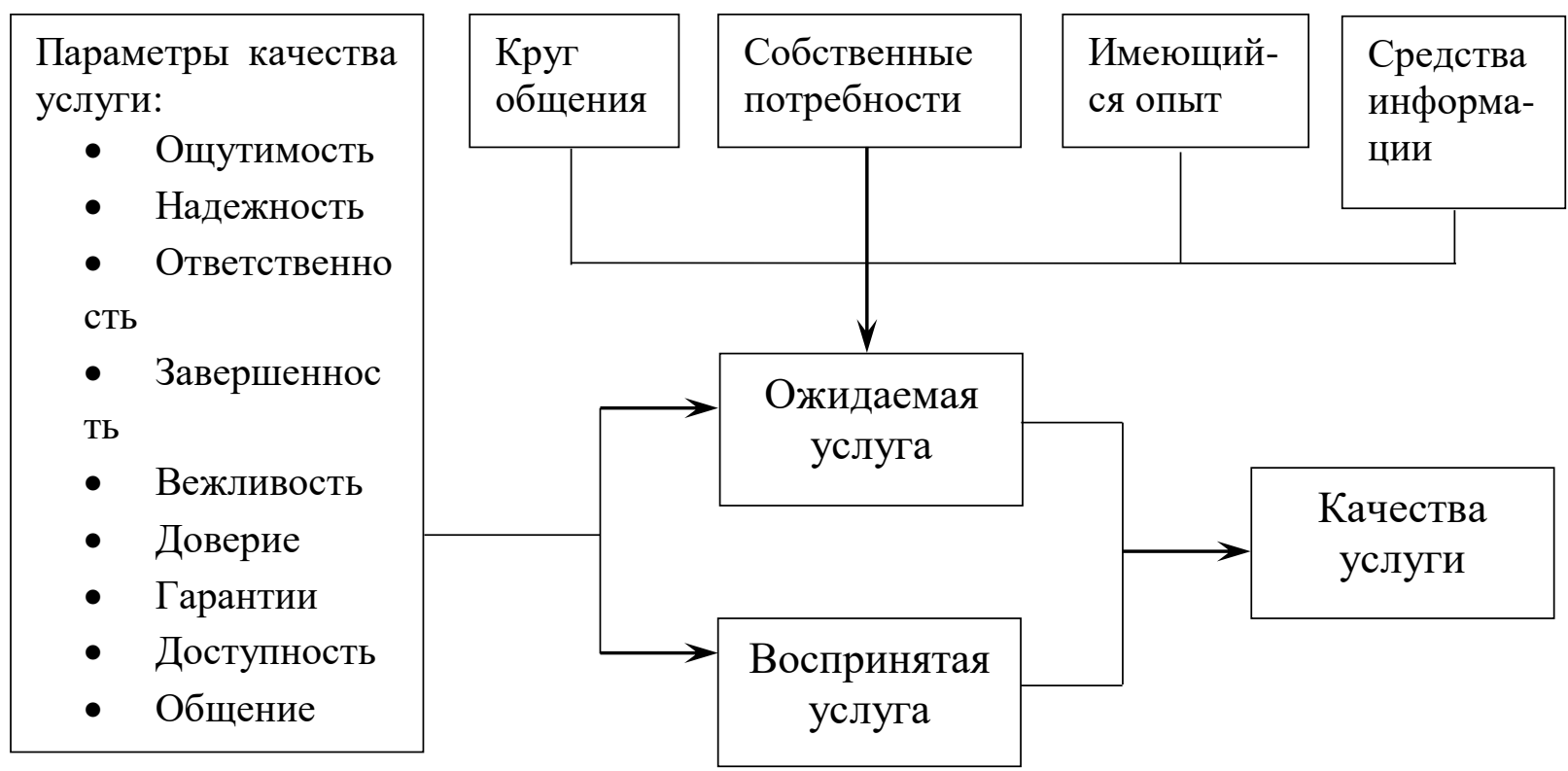

Рис. 4. Архитектура ожиданий потребителя

Во всех современных системах управления качеством в условиях положений о престижных наградах (ЕФУК, УОК, IAQ, TQM и др.) такой показатель, как степень удовлетворенности продукцией потребителя, стоит выше всех остальных, занимая в весовом отношении от $1 / 5$ до $1 / 3$ совокупных баллов. Меньше всего баллов у данного показателя - 180 (из 1000) в Положении о Премии Правительства РФ в области качества [13].

У нас есть понимание, что удовлетворенность покупателя товаром не следует сводить к потребительской привлекательности товара. Привлекательность товара накладывается на удовлетворенность, оставаясь частью удовлетворенности. Существуют товары, которые изначально, возможно, и не принадлежали к ряду привлекательных, например, подарки или что-то приобретенное «по случаю», вынужденно. Привлекательность же открылась позже, по мере использования по назначению. Но сравнение удовлетворенности и привлекательности вполне корректно и показательно. Более того, на стыке этих понятий располагается тестовая зона 


\begin{tabular}{|c|c|c|c|c|c|c|}
\hline \multirow{4}{*}{ Impact Factor: } & ISRA (India) & $=3.117$ & SIS (USA) & $=0.912$ & ICV (Poland) & $=6.630$ \\
\hline & ISI (Dubai, UAE & $=0.829$ & РИНЦ (Russia & $=0.156$ & PIF (India) & $=1.940$ \\
\hline & GIF (Australia) & $=0.564$ & ESJI (KZ) & $=8.716$ & IBI (India) & $=4.260$ \\
\hline & JIF & $=1.500$ & SJIF (Morocce & $=5.667$ & OAJI (USA) & $=0.350$ \\
\hline
\end{tabular}

характеристики степени развитости производства.

Подводя итоги анализа понятия «привлекательность товара, его взаимосвязи с ближайшими экономическими понятиями, методологически целесообразно расположить отношения данных понятий системно. В порядке проблемы для обсуждения и совершенствования предлагается следующая схема (рисунок 5)

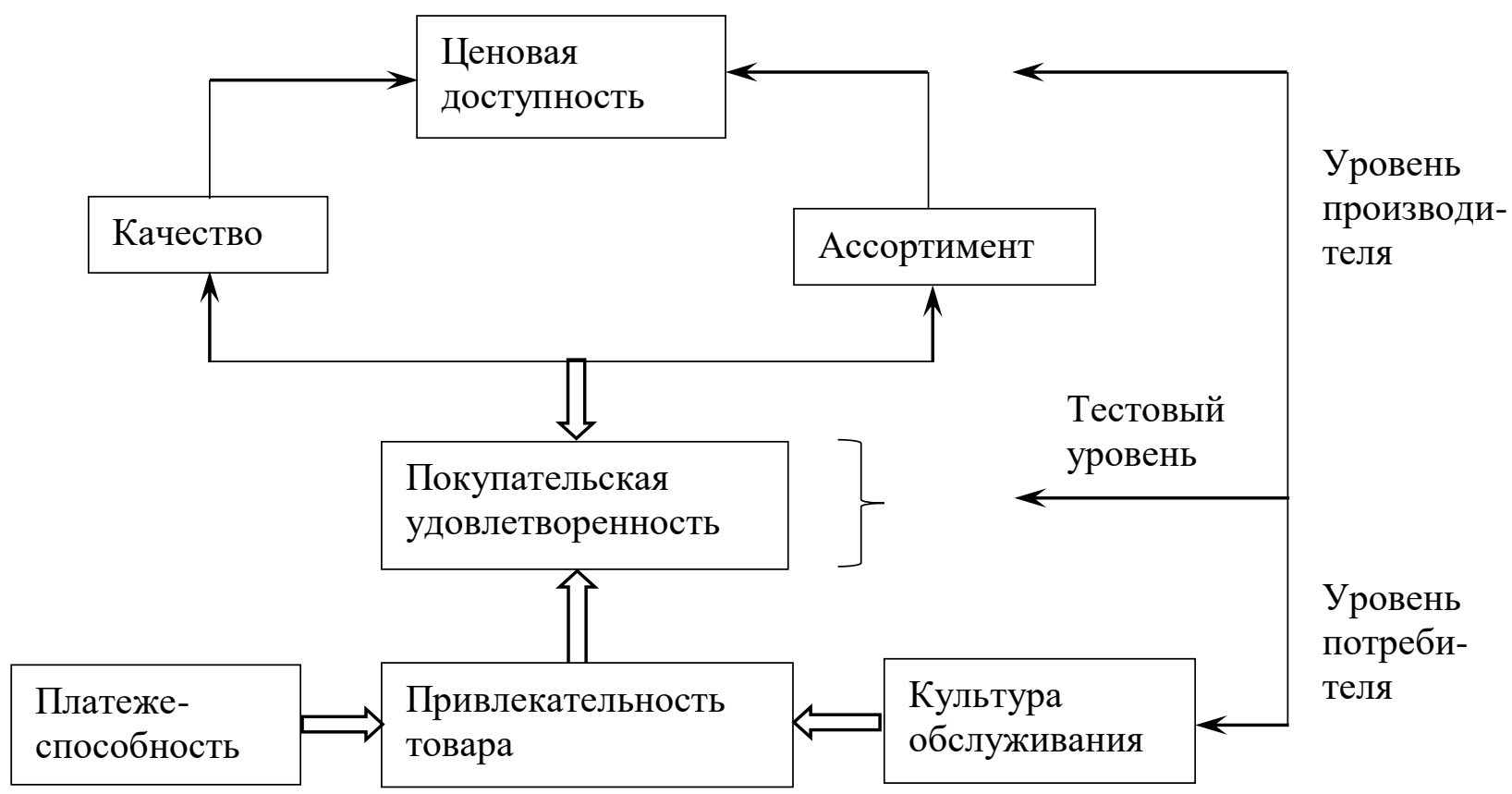

Рис. 5. Архитектура покупательской удовлетворенности.

XXI век обострил научный, философский и практический интерес к конкуренции. Масштабы, содержание, формы и значение конкуренции поставили ее в ряд глобальных проблем развития человечества с одним важным уточнением: от достижений в конкурентной борьбе выигрывает не столько само человечество, сколько отдельно взятые субъекты человеческой деятельности, начиная с личности исполнителя и управляющего, и до тех государств, в чьих интересах они работают. Поэтому организация эффективного участия в конкуренции должна рассматриваться как ведущий показатель профессиональной компетентности, духовной зрелости и политической сознательности, имея в виду, естественно, политику экономическую.

Oсобое место в этой борьбе, по другому ее не назовешь, занимает настрой самосознания, системообразующим фактором которого является профессиональная культура. Если человеческий капитал определяет рост производства, то качество образования закладывает фундамент человеческого капитала. Компетенции эффективны не сами по себе, они имеют силу, когда сформированы в качестве потребностей личности, развитой разносторонне и в гармонии своих, национальных и общечеловеческих интересов.
Формула гармоничности интересов личности предельна проста. Ее открыл 2500 лет назад Конфуций, и уточнил И. Кант, придав рациональный вид «другой человек не должен быть для тебя средством». Суммируя мысли наших великих предков, скажем: единственным надежным действенным средством устойчивого развития всех проявлений человеческой жизни будет достижение взаимозаинтересованного сосуществования людей. Применительно к производству вообще и потребительских товаров, в частности, заключение еще более упрощается до создания в конкретном производстве технических, экономических и гуманитарных (социокультурных и психологических) условий, нацеленных на качественный, востребованный и доступный продукт. Организация производства разумной может считаться только в том случае, когда она подчинена единственной цели удовлетворенного запросов потребителя. К сожалению наша современная организация экономики противопоставляет производителя и потребителя, превращая их в противников, вместо того, чтобы стимулировать действовать в единой команде.

Где же причины такой аномальности?. В чём она проявляется? Связано ли это с объективными факторами, преодолеть сопротивление чьих сил нам пока не дано, или 


\begin{tabular}{|c|c|c|c|c|c|c|}
\hline \multirow{4}{*}{ Impact Factor: } & ISRA (India) & $=3.117$ & SIS (USA) & $=0.912$ & ICV (Poland) & $=6.630$ \\
\hline & ISI (Dubai, UAE & $=0.829$ & РИНЦ (Russia) & $=0.156$ & PIF (India) & $=1.940$ \\
\hline & GIF (Australia) & $=0.564$ & ESJI (KZ) & $=\mathbf{5 . 0 1 5}$ & IBI (India) & $=4.260$ \\
\hline & JIF & $=1.500$ & SJIF (Morocco) & $=5.667$ & OAJI (USA) & $=0.350$ \\
\hline
\end{tabular}

все-таки тормозящие силы имеют инерционный характер, достались нам в наследство, внедрены в порядке модернизации и мы способны с ними бороться, а не с потребителем на рынке? Каковы же наши резервы?

Ответы на поставленные вопросы надо искать в системном анализе, который требует обращения к научной и философской теории. Не следует боятся напряжения мыслетворчества. Известный натуралист Д. Дан анализируя вслед за Ч. Дарвиным смысл конкуренции, пришел к выводу, что конкуренция в борьбе за существование не ограничивается большей и лучшей приспособленностью к обстоятельствам, она укрепляет нервную систему и развивает головной мозг. Так что начнем с философской рефлексии.

В экономике и политике известно немало явлений противоречащих природе и функциям этих сфер общественной жизни. Практическое развитие не всегда совпадает с исторической логикой. История, вопреки её разумной основы, истории осуществления деятельности человека разумного, нередко загоняет рефлексию разума в тупик. В связи с чем возникает проблема: если история социокультурной деятельности «человека разумного» должна быть, как минимум, не менее разумной и логичной, чем индивидуальный разум человека, подверженного случайности несравнимо в большей мере, чем обобществленный разум человечества, то чем же объяснить наличие общественных аномалий, своего рода «косяков»?

Они - исторические тупики, из которых нам надлежит регулярно выбираться, или продукт издержек неразвитости организации общественных отношений и управления, включая сюда ограниченное знание исторических закономерностей. Другими словами говоря, перед нами загадка истории и нам определять, где искать ключи к ее решению - в сознании либо в объективной реальности? На чем именно сосредоточить внимание? У нас нет ответа, который можно было бы аргументировать в достаточной мере. Более того, нам представляется, что правомернее было бы исследование природы этой проблемы осуществлять параллельно - и в общественном бытии, и в общественном сознании.

Разумность истории человеческой деятельности не могла не заложить логически выраженный рисунок, но отсутствие в реальной истории внелогических процессов выглядело бы так, будто сценарий истории был кем - то заранее написан и тот, кто его придумал, продолжает дирижировать ходом исторического движения. Н.Г. Чернышевский сравнил историю с Невским проспектом, проложенным по линейке. Сделал он это, чтобы подчеркнуть, что историческая

логичность

требует специфического осознания. История сравнима с порядком движения в физическом пространстве бытия, но она располагается в нем нелинейно.

В природе нет прямых линий - они условны и существуют как интервалы-отрезки движения. То же и в развитии общества, оно разумно в меру исторической конкретности. И каждая историческая конкретность несет в себе, как нечто новое, так и нерешенные или ограниченно решенные проблемы, оставляемые в наследство преходящим на смену поколениям. Историческая логика натыкается на несовершенство исторической конкретности и будет лучше понята как последовательность конкретноисторических разумностей, выстроенных из противоречий разумности человеческой деятельности, по сути относительной логичности той исторической конкретики, что сопровождает историческое восхождение обобществленного человека разумного.

$\mathrm{XX}$ век подтвердил идею исторического материализма в его марксисткой интерпретации [12]. Развитие общественной жизни опирается на движение материального производства, связующим элементом которого изначально был человек разумно-деятельный. Человеческая история выросла из труда, но современное состояние труда стало возможным только на этапе homo sapiens, что означает следующее: производство служит базой социального прогресса тогда, когда оно находит свое выражение в человеческой разумности. Чтобы быть действительной силой, производство должно соответствовать потребностям людей, потребности - проявляться в мыслях, мысли захватывать чувства, делаться убеждением.

Совершенствование производства обусловлено превращением науки в непосредственную производительную силу, техническим прогрессом, однако в не меньшей зависимости производительность и качество производящей деятельности зависит от нравственного фактора - отношения человека к труду. В этом свете показательна японская ментальность, выработанная оригинальной экономической политикой, связующей интересы собственников и наемных работников. Ее ядром является национальная традиция, уходящая в историю конфуцианства. Конфуций учил: «При управлении государством … необходимы постоянное внимание к делам и искренность в отношении к людям, умеренность в расходах и любовь к народу. И не менее важно побуждать народ к труду...». [14].

В Японии, Китае и других странах Востока можно найти примеры нравственного расстройства, но они не столько свидетельствуют о социокультурной переориентации в 


\begin{tabular}{|c|c|c|c|c|c|c|}
\hline \multirow{4}{*}{ Impact Factor: } & ISRA (India) & $=3.117$ & SIS (USA) & $=0.912$ & ICV (Poland) & $=6.630$ \\
\hline & ISI (Dubai, UAE & $=0.829$ & РИНЦ (Russia) & $=0.156$ & PIF (India) & $=1.940$ \\
\hline & GIF (Australia) & $=0.564$ & ESJI (KZ) & $=5.015$ & IBI (India) & $=4.260$ \\
\hline & JIF & $=1.500$ & SJIF (Morocco) & $=5.667$ & OAJI (USA) & $=0.350$ \\
\hline
\end{tabular}

национальном формате, сколько об исторических издержках развития национальной культуры. Там подавляющее большинство населения продолжает прислушиваться к словам и рассуждениям учителей. «Богатство и знатность, объяснял Конфуций, составляют предмет человеческих желаний, но благородный муж ими не пользуется, если они достались незаконным путем...» Как может благородный муж носить столь высокое имя, если он утратил человеколюбие? Благородный муж ни на час не расстается с человеколюбием, оно непременно с ним: и в беде, и в мирской суете». [14

Для поддержания престижа фирмы в Японии активно используется опорное явление общественной формы жизни - семья, семейные традиции, аккумулирующие силу нравственности. Фирме служит семья. Каждый член семьи, традиционно связанной с историей производства, воспринимает фирму и свою работу через призму семейной традиции, снимая нагрузку отчуждения труда, неизбежную в условиях эксплуатации. Сама эксплуатация драпируется в форму социального партнерства. Сущностные противоречия буржуазного производства остаются, однако изменяется форма их восприятия сознанием. В современной России термин «эксплуатация» не употребляется для характеристики производства, что и не удивляет при наличии существующего практического отношения к национальной культуре, особенно к образованию, официально нацеленному политикой на выработку компетенций, нужных работодателю в первую очередь.

Качество производства и качество продукта производства находятся в зависимости от технических условий - технологии, технических средств, организации производства, профессиональной квалификации организаторов и исполнителей и отношения к труду. Две последних составляющих образуют содержание понятия «субъективный фактор» или «человеческий капитал». Опираясь на достижения научно-технической революции, предприниматели стараются минимизировать соучастие «субъективного фактора» ввиду его волатильности. Не афишируя, «субъективный фактор» относят к условиям неопределенности и риска.

Проблема здесь в том, что все попытки ограничить присутствие в производстве и, главным образом, в его технологической составляющей субъективного фактора, неизбежно ведут к абсолютизации технического компонента. Он становится тотальным средством повышения производительности труда, безопасности производства и рентабельности. Тем самым управление организацией развития производства делегируется искусственному интеллекту, построенному на законах и правилах формальной логики, выражающей одну из сторон развития - консервативность.

Исходный закон, а, по существу, принцип этой логики - закон тождества. Предмет и субъект, их связь признаются неизменными. Движение сводится к его относительному моменту - покою. Покой подменяет движение и вместе с ним изменение как суть любого движения.

Ч. Дарвин говорил: природа не любит скачков и пояснял, потому что вся из них состоит. Ж. Кювье, напротив, пытался понять изменчивость видов как результат земных катаклизмов. Жизнь природы подсказывает нам, что надо бояться в мышлении логической линейности. Она эффективна, когда что-то актуально довести до совершенства в своем традиционном проявлении. Например, в случае улучшения существующего ассортимента, достижения рационального соотношения покупательских требований к известному привлекательному товару, его качеству и цены. Но всему приходит край, совершенствование не исключение, следовательно, нужно заранее искать варианты интересного перспективного развития товарного ряда, думать не о том, что в принципе уже есть, улучшать имеющееся, а пытаться фантазировать системно, опережать спрос новациями. По другому сегодня управлять потребностями покупателей нерационально.

Мышление наше в той своей части, которую называют креативной, творческой, достаточно просторно для новаторских действий. Только важно понимать, что за горизонтом известного аристотелевская логика терпит свой эвристический потенциал. Перспективное мышление - это мышление, пытающееся «схватить» направление перемен в товарном производстве. Здесь доминирует возможность в мышлении опережающего отражения действительности - свойство открытое П.Анохиным. Физиологические основания предвидеть изменения есть, психические предпосылки в виде воли, потребности, эмоций также естественны. Остается искать логические инструменты. Стрелку движения следует перевести с аристотелевской формальной логики на гегелевскую диалектическую, опирающуюся на принцип развития содержания понятий и изменения самих понятий. Представляя особенность диалектической логики, ее коренное отличие от логики Аристотеля, Г. Гегель писал: «В рассудочной логике понятие рассматривается обычно как простая форма мышления и, говоря более точно, как общее представление, ... будто понятие как таковое есть нечто мертвое, пустое, абстрактное». И уточнял: «Конечно понятие 


\begin{tabular}{|c|c|c|c|c|c|c|}
\hline \multirow{4}{*}{ Impact Factor: } & ISRA (India) & $=3.117$ & SIS (USA) & $=0.912$ & ICV (Poland) & $=6.630$ \\
\hline & ISI (Dubai, UAE & $=0.829$ & РИНЦ (Russia & $=0.156$ & PIF (India) & $=1.940$ \\
\hline & GIF (Australia) & $=0.564$ & ESJI (KZ) & $=\mathbf{5 . 0 1 5}$ & IBI (India) & $=4.260$ \\
\hline & JIF & $=1.500$ & SJIF (Morocco & $=5.667$ & OAJI (USA) & $=0.350$ \\
\hline
\end{tabular}

следует рассматривать как форму, но как бесконечную, творческую форму». [15].

Совсем не случайно единомышленники К. Маркса отмечали, что основоположник универсального понимания диалектики не оставил наследникам учебника, так как им должна была стать логика анализа движения производства в «Капитале». К. Маркс показал, как логическая ограниченность мышления управляющих производством сводит процесс к управлению капиталом и доводит производство не только до кризиса, провоцируемого перепроизводством, но и до социально политического напряжения. Развитие политической экономии после К. Маркса было ожидаемо, подчинено исторической реабилитации капитализма. Интеллектуальные и политические силы сконцентрировали на отождествлении совершенства товарного производства с его буржуазной формой организации.

Здесь и пригодились особенности аристотелевской логики, нацеленной на неизменность условий умозаключения. Если товарное производство является единственной универсальной реальностью объективного исторического процесса в условиях развитого общества, то ему самой историей суждено осуществляться достойно исключительно в форме буржуазной организации. Таким образом, мышление потребителя, также настроенное в общем виде на формально - логический тип действия, подводят к окончательному выводу: период предшествующий капитализму, был доисторическим, всего лишь становлением. Истинная история товарного производства творится в буржуазной форме. Объективная реальность воплотилась в абсолютную, то есть внеисторическую форму. Дальнейшая история может быть понята только как восхождение капитализма к высшим и абсолютным достижениям и всемерная защита устойчивости буржуазного строя - оптимального для товарного хозяйства.

Сила логики в способности выстроить внутренне непротиворечивую теорию, но истинность любой теории проверяется не одной ее последовательностью. Здесь особую значимость имеет соответствие следствий теории жизненным реалиям. Экономическая теория тестируется в массовом порядке, ибо ее результаты касаются непосредственно всех. Производителями люди могут быть и не быть, а потребляют продукты производства все и все хотят сделать потребление устойчиво качественным и соответствующим платежной способности.

Начиная с ремесленнического труда и цеховой формы его организации, качество товара вытеснило все прочие признаки производства на второй план. Пока разделение труда носило цеховую форму, а внутри цеха каждый производил товар вплоть до конечной товарной формы и полной мерой гарантировал качество своим клеймом, качество производства и качество товара пребывали в единстве существования, а проблема качества товара упрощалась, сводясь к соблюдению технологического стандарта производства. Производство было способом жизнеобеспечения производителя, поэтому актуальность качества товара снималась спецификой его отношения к производству.

На рынке товар был качественным, опасаться следовало только фальсификата, который не имел нынешних масштабов и решительно пресекался как государством, так и саморегулированием торговли. Для массового производства, явившегося основным следствием промышленной революции, проблема заинтересованности производителя в качестве товара среди общественно значимых не отмечалась. Она, бесспорно, была, но характер производства не давал ей выйти из сферы частного сознания и материализоваться в товарном ассортименте.

Потенциально данная проблема появилась еще до товарного производства, однако в то время она носила форму абстрактной возможности, ибо действительностью была актуальность количества произведенного продукта. Производство только набирало силу источника жизнеспособности человека. Сначала родилась проблема количества, нарастание количества поставило вопрос о качестве, так как появилась возможность сравнения произведенного продукта, наметилась специализация производства в зависимости от своеобразия естественной среды.

Развивающийся рынок требовал разнообразия товаров. Нужны были товары в рамках различия покупательской способности потребителей. Фабрично - заводское производство, опирающееся на техническую базу, открывало перспективу варьирования качеством товара. Жесткие ограничения по производству, отличавшие цеховую деятельность отступили. На рынке появились товары разного качества. В британской философии Просвещения активно обсуждалось само понятие качества. Дж. Локк предложил версию сочетания в определении качества объективных свойств предметов и субъективного восприятия их сознанием.

В разделении признаков качества на «первичные» и «вторичные» имелось рациональное начало, связанное со спецификой «второй природы» - вещей, преобразованных из 


\begin{tabular}{|c|c|c|c|c|c|c|}
\hline \multirow{4}{*}{ Impact Factor: } & ISRA (India) & $=3.117$ & SIS (USA) & $=0.912$ & ICV (Poland) & $=6.630$ \\
\hline & ISI (Dubai, UAE & $=0.829$ & РИНЦ (Russia) & $=0.156$ & PIF (India) & $=1.940$ \\
\hline & GIF (Australia) & $=0.564$ & ESJI (KZ) & $=\mathbf{5 . 0 1 5}$ & IBI (India) & $=4.260$ \\
\hline & JIF & $=1.500$ & SJIF (Morocco) & $=5.667$ & OAJI (USA) & $=0.350$ \\
\hline
\end{tabular}

естественного состояния человеческим трудом. «Первичные» качества товара или его сырья обусловлены природной реальностью и в полной мере независимы от человека. «Вторичные» признаки, напротив, находятся в зависимости от человеческого труда. Именно труд их выявляет, либо создает, поэтому и качество трансформированных трудом предметов должно определяться с человеческой оценкой. Включение человека как фактора производства качества товара усиливает влияние субъекта труда на качество производства и качество произведенного товара. В связи с чем увеличивается нагрузка на процесс управления.

Управление подчиняется решению задачи устойчивого получения качественного продукта. Как в любой задаче, здесь необходимо:

- четко определиться с тем, что такое «качество»?

- понять, что специфично для качества товара?

- разобраться, как связаны «качество» товарного производства и его массовость, проследить механизм взаимодействия качественных изменений с количественными.

- раскрыть системное положение проблемы качества массового производства в контексте развивающейся экономики.

Лишь получив ответы на перечисленные вопросы, мы сможем продуктивно исследовать проблему: «Насколько реалистично наше стремление придать массовому производителю потребность в качественности товарного результата», говоря иначе, «возможно ли достаточно мотивировать получение качественного продукта изнутри массового производства?». Пока, к сожалению, управление качеством осуществляется привнесением в производство идей, разработанных не в нем, а в «чистой» теории управления.

Подобный механизм управления качеством возвышает значение научного анализа, определяя самодвижению производства к качеству роль подсобного, опытного хозяйства. Ретроспективный взгляд на историю осмысления того, как следует управлять качеством производства в общем виде, демонстрирует наглядно, что история эта очень похожа на движение мысли по принципу «проб и ошибок». Каждая следующая «теория» после С. Кольта (1870-е годы), - Г. Лаланда, Г. Форда, А. Файоля, М. Вебера, $Ф$. Тейлора, В. Шухерта, Э. Деминга, И. Исикава, И. Джурана, Ф. Кросби, А. Фейгенбаума неизменно напоминала выход из тупика, в который заводила ее предшественница, пока в итоге не заменили ключевое понятие СК на СМК - «Систему менеджмента качества».
Сравнение СМК с СК позволяет рассмотреть тренд движения - стремление, разрабатывая новый подход к управлению качеством, преодолеть узко технологический взгляд на качество как некий стандарт, ограниченный процессом производства вне условий потребления.

Сложившееся под влиянием экономической рациональности толкование качества товара не отражает социокультурный статус товара, по крайней мере, товара потребительского ряда. Качественную характеристику товара, предназначенного для массового потребления, целесообразно искать на стыке производственных, хозяйственно - бытовых и социокультурных его достоинств. Причем желательно, чтобы товар не только удовлетворял существующие потребности, но и стимулировал их культурное развитие, служил инструментом развития личности потребителя. Человеческий капитал участвует в творении продукта производства, а производство призвано способствовать совершенствованию личности. Иного способа преодолеть отчуждение в условиях абсолютизации частной собственности и ее непропорциональных труду размеров распределения не существует. Только придание труду креативности и соответствующего творчеству вознаграждения можно «снять», выражаясь в терминах гегелевской философии, напряжение отчуждения. Качество товара в широком смысле может рассматриваться как фактор социального прогресса и как тест социокультурных достижений общественного развития.

В определении качества наиболее часто встречающимся недостатком является отсутствие системности. Качество определяется как совокупность существенных свойств. Обычным методом подбора таковых выступает способ пирамидального расположения свойств предмета. В основании остаются важные, но не определяющие, а по мере восхождения к вершине формируется иерархия оставшихся свойств. На вершине мы получаем сумму главных свойств, которые и включаются в определение качества предмета. Г. Гегель в свое время остроумно определил качество от противного - «качество есть то, теряя что, предмет перестает быть собою».

Следуя примеру великого мыслителя, определим «обувь», как «одежду для ног». Насколько верным будет это определение? Для обуви, вероятно, да. Для качества обуви вряд ли. Если лишить обувь способности быть «одеждой ног», то она действительно не будет обувью. Если же сохранить обуви только свойственную ей способность, то неопределенным будет требуемое качество изделия. «Одежда для ног» 


\begin{tabular}{|c|c|c|c|c|c|c|}
\hline \multirow{4}{*}{ Impact Factor: } & ISRA (India) & $=3.117$ & SIS (USA) & $=0.912$ & ICV (Poland) & $=6.630$ \\
\hline & ISI (Dubai, UAE & $=0.829$ & РИНЦ (Russia) & $=0.156$ & PIF (India) & $=1.940$ \\
\hline & GIF (Australia) & $=0.564$ & ESJI (KZ) & $=5.015$ & IBI (India) & $=4.260$ \\
\hline & JIF & $=1.500$ & SJIF (Morocco) & $=5.667$ & OAJI (USA) & $=0.350$ \\
\hline
\end{tabular}

может быть опасной из-за токсичности материала, средств крепления, неудобной для движения конструкции. Формально выстроенное требование к предмету не совпадает с качеством предмета. Оно значимо в качестве предпосылки к качественной определенности товара. К определению качества товара надо идти от его функциональной предназначенности. Функциональное же предназначение следует рассматривать как состояние отношений формально определяющего предмет свойства со спецификой эксплуатации предмета, его товарным назначением, заключенном в потребительской стоимости товара.

Ноги, для которых пошивают одежду в виде обуви, представляют часть живого организма. Это не колодки и не конечности трупа, также предназначенные для определенной одежды. Одежда для ног не будет обувью до тех пор, пока не получат достаточные доказательства ее безопасности - гигиенической, эргономической, производственной, хозяйственно - бытовой. Качество - это не совокупность существенных свойств товара, оно есть их система, системообразующим признаком которой действительно является способность выполнять некоторую формально наиболее значимую функцию. Ее и закладывают в основание определения качества товара «выращивая» затем саму систему, как выращивают из случайной песчинки жемчужину в раковине или Периодическую систему химических элементов из атомного веса.

Г. Гегель был прав в своем определении качества, начинать всегда лучше с того, что «на виду», чтобы потом наращивать определение. Вокруг ядра атома существует электронная оболочка и вместе они дают определение атома. В определение мы закладываем качество, раскрывая его впоследствии в совокупности конкретизирующих свойств.

С философской точки зрения качество предмета, отражая многообразие мира, воспроизводит в себе это объективно существующие предметное различие. Качество товара, особенно массового непосредственного потребления человеком, требует дополнительного уточнения, связанного с ответственностью производителя за безопасность использования изделия. Качество товаров «ширпотреба» более сложно структурированно. В его определение входит системное расположение основных компетенций технического и гуманитарного значения.

Обувь своим качеством, по определению, должна обеспечивать взаимодействие двух основополагающих компетенций - безопасности и комфортности при эксплуатации. Эстетические свойства обуви подчинены им и в них упакованы.
C их помощью производитель «завлекает» потребителя подобно цветкам растений, призывающих насекомых, производящих через потребление работу опыления.

Культурную оценку изделия ошибочно упрощать до уровня эстетической ценности изделий. Культурный статус товара синтезирует в себе и культуру исполнения, и культуру сознания производителя, принимающего решение какие материалы использовать, в чьих интересах действовать - рентабельности производства или потребностей потребителя, доверяющего производителю. Восходя, мы без труда можем подняться и до самого верха - культуры общественного сознания. В каких-то странах не воруют, считают обман подлостью, а в иных всё на этих пороках построено, они легализованы, ибо вросли в национальный менталитет.

Подмена философского понимания качества товара экономическим закономерна для экономики, нацеленной преимущественно на получение прибыли, наращивание капитала в частных интересах. Экономическая доминанта в характеристике качества имеет идеологическую базу. В том же контексте следует рассматривать и стремление отделить экономику от социальнокультурного развития. Идея, согласно которой экономическое движение должно быть абсолютно независимо от политического надзора и гуманитарных функций, всё внеэкономическое обеспечивается налогами с экономики, набирает силу, а главное ее поддерживает власть.

Попытки противопоставить, этой логики, здравый смысл общественного развития как прогресса личности и межличностных отношений в рамках социальной организации исторического процесса неэффективны. Им отведена роль локального общественного мнения, которое никогда не отличалось особой солидарностью. Философский системный анализ качества и дефектов его толкования остается уделом профессиональной рефлексии.

Казалось бы, перед нами сугубо теоретическая проблема: что называть действительным качеством товара и как выглядит система качественных свойств в характеристики товара? В действительности, при практическом приложении, она разрастается в идеологическую проблему: каким позволительно видеть качество товара в современных конкретно-исторических обстоятельствах общественного культурного развития.

Упрощение понимания качества товара путем сведения его к его свойствам, обеспечивающим рентабельность производства, делает производство, а не потребителя системообразующим фактором получения «качественности» товара, что противоречит качественности развитой экономики 


\begin{tabular}{|c|c|c|c|c|c|c|}
\hline \multirow{4}{*}{ Impact Factor: } & ISRA (India) & $=3.117$ & SIS (USA) & $=0.912$ & ICV (Poland) & $=6.630$ \\
\hline & ISI (Dubai, UAE & $=0.829$ & РИНЦ (Russia) & $=0.156$ & PIF (India) & $=1.940$ \\
\hline & GIF (Australia) & $=0.564$ & ESJI (KZ) & $=\mathbf{5 . 0 1 5}$ & IBI (India) & $=4.260$ \\
\hline & JIF & $=1.500$ & SJIF (Morocco) & $=5.667$ & OAJI (USA) & $=0.350$ \\
\hline
\end{tabular}

«постиндустриального»,

«нового индустриального» и даже «индустриального» общества. На заре человечества потребитель радовался всему, что удавалось произвести. Производство было определяющей стороной в отношениях с потребителем. Сегодня считают рынок движущей силой развития производства. На рынке инициатива принадлежит покупателю. Переход к принципу: «Покупатель всегда прав!» предполагает определять качество товара его потребителем.

Экономическая доминанта в характеристике качества товара явно не современна в философском смысле, но в ней выражена суть буржуазной основы существующей экономики, следовательно, и политически, и идеологически ее будут отстаивать. Тем более, что в определенном смысле это интересно, в частности для решения проблемы мобилизации производственного потенциала на получение востребованного товара в значительных объемах, правда само качество такого товара будет условным, - « экономическим». Получило официальное признание понятие «эконом класс» в развитие понятия «произведено для реализации в России».

Мы уже подчеркивали, что на протяжении 130 лет буржуазные экономисты создавали модели эффективного производства качественного товара, востребованного рынком, акцентируя внимание на экономическое содержание качества. Загнав движение производства в тупик экономическими моделями качества, топ менеджеры совместно с теоретиками - экономистами, обособившими профиль своего научного интереса от социокультурных целей производства материальных благ, вынуждены были признать потребителя не в качестве рыночного анти субъекта, а как партнера, соучастника производственного процесса.

Признание потребителя соратником равносильно включению его в команду по разработке производственной политики, правда, формально, ибо он остается в прежнем положении контрагента. Чтобы изменилось понимание качества, нужно совершенствование производства начинать с интересов потребителя, отражать их в свойствах товара, а потом думать, как оптимизировать организацию его массового изготовления.

В конечном счете, вначале допустимо и компромиссное решение, обоснованное возможностями производства и необходимостью двигаться путем расширения этих возможностей. Сейчас покупатель принципиально остается холопом при производителе - барине и политическом протекторате интересов крупного капитала. Интересы массового потребителя продвигают поступью японских женщин, в то время как доминирование в производстве интересов компаний движутся парадным шагом победителей. Темп движения не сопоставим, заметного преимущества в продвижении интересов потребителя нет и пока не предвидеться.

Потребителя с его интересом в качестве товара теоретически не исключают из разработки стратегии, тактики и рекламы. Сошлемся на Б.С. Алешина с соавторами: «Чтобы стратегия качества была успешной, как внутренний так и внешний потребитель должны быть не только удовлетворены и вовлечены в процесс, обеспечивающий это удовлетворение, но и принимать непосредственное участие в непрерывном улучшении качества этого процесса» [16] с этой целью усовершенствовали систему Kaizyo; заменив её новой редакцией Kaizen. Изменения в организации управления качеством выявили преимущества тех стран, где массовый потребитель - он же и работник производства чувствует себя более комфортно, ощущает свое соучастие в развитии производства. Во второй половине 1980-х годов японские компании получали в 40 раз(!) больше предложений по совершенствованию производственного процесса от своих работников, чем компании США (40 млн. против 1 млн.). Показательно и то, что свыше 90 процентов предложений, так или иначе, были использованы.

Идеология качества перестраивается на новую - потребительскую ориентацию крайне неохотно и половинчато. Система управления качеством ИСО 9000 (в РФ - ГОСТ Р ИСО 900096) была внедрена в мировую практику 30 лет назад. Ее исходное положение (№1): «Качество продукции - это характерный управляемый объект», задает генеральное направление в понимании качества. Качество - продукт производства. В пункте №2 уточняются места участников, влияющих на качество товара: «цель управления качеством - создание продукции такого уровня качества, который удовлетворяет определенным установленным, требованиям, потребностям». Чтобы ясно было о чьих требованиях и потребностях идёт речь, в конце пункта читаем через запятую - «запросам потребителя».

Интересы потребителя учтены, но по остаточному принципу. $\mathrm{O}$ них вспоминают в последнюю очередь, «если резервы производства позволяют». В научных и популярных источниках можно встретить объяснение такому раскладу интересов - технически сложные товары и их совершенствование - удел специалистов. Складывается впечатление, что специалисты не потребители. 


\begin{tabular}{|c|c|c|c|c|c|c|}
\hline \multirow{4}{*}{ Impact Factor: } & ISRA (India) & $=3.117$ & SIS (USA) & $=0.912$ & ICV (Poland) & $=6.630$ \\
\hline & ISI (Dubai, UAE & $=0.829$ & РИНЦ (Russia) & $=0.156$ & PIF (India) & $=1.940$ \\
\hline & GIF (Australia) & $=0.564$ & ESJI (KZ) & $=\mathbf{5 . 0 1 5}$ & IBI (India) & $=4.260$ \\
\hline & JIF & $=1.500$ & SJIF (Morocco) & $=5.667$ & OAJI (USA) & $=0.350$ \\
\hline
\end{tabular}

B ISO 9000 - 2000 впервые на самом верху списка появляется потребитель. Первый принцип СМК констатирует: «Ориентация на потребителя». Именно потребитель декларирует свойства качества. Статус предприятия зависит от того насколько качество предлагаемого товара удовлетворяет запросы к качеству покупателей. Предприятие должно понимать их текущие и будущие потребности, выполнять их требования и стремиться превзойти их ожидания [12].

Но не следует спешить радоваться происшедшим переменам. Механизм управления качеством по-прежнему настроен на разработку качества технологии производства, а не на получение качественного продукта. Качество деятельности предприятия, как и раньше тестируется на предмет поддержания качества организации производства. Интересы потребителя остаются «на потом». В РФ представлены все ведущие международные регистраторы качества менеджмента качества: Веритас, Британский институт стандартов, Регистратор Ллойда, общества надзора (TUV). Помимо них на рынке управления качеством свои услуги предлагают многочисленные доморощенные и совместные фирмы, имеющие отношение к сертификации качества производства и изделий. Проблема не в том, чтобы найти искомую организацию, а в том, что все они «заточены» на производство или продукт вне контекста с интересами потребителей, которые достаточно специфичны и далеко не во всем совпадают со взглядами на качество производителей.

Диалектика рынка, объединяющего производителя и потребителя проста - они противоположности, существующие исключительно в единстве, поэтому нужно искать равновесие интересов обоих субъектов, чтобы придать производству качественных товаров устойчивый характер, служащий защитой от рецессий и кризисов. Кризисы перепроизводства - классические для капитализма XIX и первой половины XX столетий сделались историей. На смену им пришли финансовые системные потрясения. Специалисты ищут панацею в качественной, умной, рачительной, щадящей (lean production) экономики. «Исторический опыт свидетельствует, что с повышением внимания к качеству начинался выход из кризисных ситуаций во многих странах. С помощью государственной политики, ориентированной на повышение качества, преодолевались крупномасштабные кризисы в Японии и Германии конца 40-х годов. Кризисные ситуации на рынках США и Европы, возникшие в конце 80-х - начале 90-х годов, заставили не только отдельные корпорации, но и целые страны -
Швецию, Великобританию, США - обратить внимание на улучшение качества, как единственное средство, помогающее национальной экономике устоять под натиском конкурентов» [12].

Солидаризируясь с выше изложенным анализом экономической истории второй половины XX - первых двух десятилетий XXI веков, от себя выразим удивление, как случилось, что при определении новейшего общественного развития через качество, сам подход к пониманию качества радикально не модернизировался. Тотальность значения качества предполагает пересмотр содержания понятия «качества» и новый взгляд на факторы, обеспечивающие действительное качество деятельности и ее продукта. Системообразующее положение фактора качества в социальном прогрессе обуславливает также и новое политическое отношение к качеству. Требуется ориентация развития производства на внутренние - не привнесенные посылы.

Управление качеством должно идти от потребности. Именно в ней, а не в награждении за качественный труд в виде поощрений истинное начало новой экономической политики. Поощрение, естественно, никто не собирается отменять, их меняют местами с мотивацией. Сегодня поощрение побуждает к требуемому качеству действия, завтра культура профессионального отношения к труду будет достраиваться поощрениями. Движение наиболее производительно именно в форме самодвижения. Внешнее побуждение менее эффективно. Вознаграждение должно соответствовать качеству труда и устойчиво мотивировать труд.

$$
\text { Смена качественной стратегии }
$$
экономической политики с побуждения к качественному производству на формирование потребности в качественном продукте не очередная попытка реанимировать экономический романтизм и не коммунистическая ностальгия по потребности культурного человека в труде как может показаться тем специалистам, кто перестроился с политической экономии на экономистику, низведя диалектический анализ до статистического, приспособленного к волотильности современного производства. Речь идет о решении системообразующей проблемы истории - об отношении личности к обществу и общества к личности, кому какая сторона данного противоречия больше импонирует, но в принципе это всего лишь двойная спираль социального прогресса. Развитое общество тестируется как условие развития личности. В свою очередь развитое общество есть само продукт культурной деятельности личности. 


\begin{tabular}{|c|c|c|c|c|c|c|}
\hline \multirow{4}{*}{ Impact Factor: } & ISRA (India) & $=3.117$ & SIS (USA) & $=0.912$ & ICV (Poland) & $=6.630$ \\
\hline & ISI (Dubai, UAE & $=0.829$ & РИНЦ (Russia & $=0.156$ & PIF (India) & $=1.940$ \\
\hline & GIF (Australia) & $=0.564$ & ESJI (KZ) & $=\mathbf{5 . 0 1 5}$ & IBI (India) & $=4.260$ \\
\hline & JIF & $=1.500$ & SJIF (Morocco & $=5.667$ & OAJI (USA) & $=0.350$ \\
\hline
\end{tabular}

Формально-логический вывод из взаимозависимости личности и общество очевиден: надо их отношении выстроить в гармонии, на основе осознания взаимного интереса, доведя интересы до степени естественно-необходимой потребности друг в друге. Сейчас мы переживаем исторический этап формально-абстрактного осознания личностью и субъектами, определяющими политику, базового противоречия развития. Личность и общество как бы притираются в движении, ищут точки взаимного роста. Отчасти удачно, примеров немало - массовое производство, свобода доступа к образованию, источникам культурного развития, политическая демократия, продвижение культуры природопользования, солидарность в противоборстве с экстремистскими устремлениями, совместное пользование научно-техническими достижениями, укрепление авторитета идеи толерантности.

Особое место в этом перечне должно занять стремление к качественной экономики. Суть здесь следующая: противоположности, по определению, взаимно отчуждаются. Диалектические противоположности, к которым принадлежат личность и общество отличаются выгодно тем, что единство в их отношениях заложено при возникновении. Его только надо довести до генерального положения за счет восхождения от формально-необходимого этапа к абсолютно необходимому, нагружая процесс реальным содержанием, предметно демонстрируя преимущества взаимодействия. Иного пути преодоления, объективно заложенного в отношения противоположностей личности и общества отчуждения нет. Через качество деятельности - к качеству социального совершенствования. Неестественно отчуждать то, что служит реальным условием твоего развития. В условиях классического капитализма отчуждение было предпосылкой достижения власти капитала, и сама политическая организация общества приспосабливалась откровенно к обеспечению буржуазного государства. Демократия была адаптирована к буржуазному общественному устройству.

Революции 1917 года в России и последующую историю СССР надо оценивать не столько как национальные достижения, сколько как перелом в истории классического капитализма, переход к постклассическому. Господство частной собственности и преимущества капитала остались неприкосновенными, но в общественной надстройке свершились существенные перемены. Классовый антагонизм уступил место социальному партнерству. Доступ к капиталу привел к возникновению различных форм ассоциативного использования его в производстве. Культурный прогресс сопровождался интересом к качеству жизни, изменением самого этого понятия. Мировые катаклизмы, бесспорно, не просто напугали народы Европы, Азии. Они отодвинули сознание от пропасти крайних интересов в решении противоречий.

Отчуждение личности в труде не преодолено, но развитие объективно (общество) и субъективно(личность) осуществлялось через взаимодвижение. Сложились определенные условия снятия отчуждения. И новый подход к качеству-потребительски-производственный является вехой на пути сближения основных субъектов общественной жизни. Он заставит вносить коррективы в экономическую политику, вернет системное понимание общества, ограничив стремление разложить общественную жизнь «по полочкам».

Качественный вектор развития экономики, разумеется, потребует дополнительные расходы, но на то и государство с его экономическими инструментами, чтобы постараться их компенсировать. И рынок наверняка позитивно отреагирует на качественный товар своей активностью.

В нашем представлении само по себе существование частной собственности в многообразии форм ее реализации не является достаточным основанием отчуждения в труде личности. К. Маркс, разрабатывая идею отчуждения Г. Гегеля, по-видимому, имел ввиду определенный способ организации труда, связанный с абсолютизацией господства частной собственности. Частная собственность служит потенциальной экономической базой эксплуатации. Но эксплуатация - не имманентно присущий ей признак. Одной частной собственности для эксплуатации явно недостаточно. Что же до противоположной частной собственности общественной (общенародной), которой управляет государство и служит реальным субъектом собственности, то и она не содержит в себе экономических гарантий преодоления отчуждения, в чем не сложно убедиться на опыте деятельности отечественных госмонополистов.

Складывается впечатление, что экономические основания отчуждения надо искать не в собственности, а в распределении. Экономические противоречия непреодолимы, но они допускают управление, задача которого контролировать характер противоречий, держать их в пределах несущественных, приемлемых различий, не испытывающих существующее единство производства на историческую целесообразность. 


\begin{tabular}{|c|c|c|c|c|c|c|}
\hline \multirow{4}{*}{ Impact Factor: } & ISRA (India) & $=3.117$ & SIS (USA) & $=0.912$ & ICV (Poland) & $=6.630$ \\
\hline & ISI (Dubai, UAE & $=0.829$ & РИНЦ (Russia) & $=0.156$ & PIF (India) & $=1.940$ \\
\hline & GIF (Australia) & $=0.564$ & ESJI (KZ) & $=5.015$ & IBI (India) & $=4.260$ \\
\hline & JIF & $=1.500$ & SJIF (Morocco) & $=5.667$ & OAJI (USA) & $=0.350$ \\
\hline
\end{tabular}

К месту вспомнить еще об одном наблюдении Г. Гегеля, признанным Ф. Энгельсом в качестве важнейшего в понимании диалектики развития: «Все разумное действительно, все действительное разумно». Г. Гегель сумел открыть основания необходимости системных преобразований общественных отношений, включая экономические.

В развитии есть два состояния, которые воспринимаются в форме существования, однако различаются внутри общего статуса своего проявления - «реальное существование» «реальность» и «действительное существование» - «действительность». Эти формы существования принципиально различаются по основанию. «Действительно существующее» опирается на необходимость быть своей форме, она представляет развивающуюся реальность. «Реально существующее» прошло стадию своей необходимости, перестало быть фактором развития, потеряло актуальность. Оно тормозит процесс развития. Так как развитие мышления и общества Г. Гегель понимал в виде движения к абсолютной разумности, то необходимость действительного он отождествлял с реальностью.

Можно, конечно выжимать из разработанного ассортимента и налаженной технологии производства все до последнего рубля. Вопрос: нужно ли это делать? Время движется вперёд в определенном режиме, «посвоему», объективно скроенному «расписанию». Не попадёшь в ритм, отстанешь, перестанешь соответствовать изменившимся требованиям. Искусство управления - управление производством не исключение, состоит в способности не «выпасть» из современности, тогда всегда будешь делать это, сообразуясь с разумностью. Разумность оградит от большинства проблем. «Семь смертельных болезней» Э. Деминга уместятся в одну - не выпасть с определением товара и организацией производства из временного цикла.

Сделать такое способны только те, кто в состоянии мобилизовать человеческий капитал, правильно сосредоточить финансовые и технические ресурсы на решение этой задачи. Без умения контролировать «пульс» времени понимать конкретную экономическую и социокультурную ситуацию, состояние потребительских интересов, реальные возможности производства, обрести устойчивость положения в условиях возрастающей конкуренции на рынке шансов нет. Сделаем еще одно прибавление - на качественную ориентацию развития производства и станет ясным общий вывод: путь экономической разумности лежит через создание действительных условий формирования потребности в качественной продукции.
Тестироваться эта потребность должна ответственностью перед потребителем как перед самим собой. Древняя мудрость Конфуция: Относись к другим так, как ты хотел, чтобы они относились к тебе, не устарела, напротив, следование ей обеспечило преимущества в экономическом прогрессе странам Азии.

Конкретность достижения разумности в современном качественно ориентированном производстве - в солидарности человеческого капитала:

\section{- внутренней}

солидарности производителей, их потребность в качестве,

- внешней солидарности с потребителем, учёт интересов последних,

- солидарности в понимании качества на основе сочетания экономических и социокультурных подходов,

- последовательности и взвешенности экономической политики государство по ориентации рынка, индуцировании интересов качества в развитии рынка инструментами хозяйственного механизма.

Мы пытались определить и суммировать основные условия достижения солидарности. Насколько позволяет нам анализ литературных данных, это делается впервые, поэтому уточнения и дополнения будут восприняты позитивно.

Итак, что нужно рассматривать как необходимые условия достижения коренного перелома в отношении к качеству производства действительно качественного товара - перехода от этапа внешнего аудита к этапу внутренней гарантии, формирующейся посредством становления потребности создавать товар, требуемого качества потребителем.

- Наличие конкуренции на рынке качественного профессионального труда, чтобы было четкое понимание необходимости работать в соответствии с потребностями товарного рынка. По-другому рынок не позволит занять устойчивое место на нем.

- Существенное повышение покупательской способности. Достижение того уровня, который позволяет осуществлять выбор нужного товара. Качественный товар не может по определению быть дешевым, но его можно сделать доступным с помощью рыночных механизмов.

- Высокий уровень профессиональной подготовки производителей, обеспечивающийся на основе формирования профессиональной культуры и национального самосознания. Главным должно быть воспитание отношения к труду как делу, посвятившему свою жизнь. Развернутое просвещение потребителей, восприятия их в качестве субъектов общего дела. 


\begin{tabular}{|c|c|c|c|c|c|c|}
\hline \multirow{4}{*}{ Impact Factor: } & ISRA (India) & $=3.117$ & SIS (USA) & $=0.912$ & ICV (Poland) & $=6.630$ \\
\hline & ISI (Dubai, UAE & $=0.829$ & РИНЦ (Russia & $=0.156$ & PIF (India) & $=1.940$ \\
\hline & GIF (Australia) & $=0.564$ & ESJI (KZ) & $=\mathbf{5 . 0 1 5}$ & IBI (India) & $=4.260$ \\
\hline & JIF & $=1.500$ & SJIF (Morocco & $=5.667$ & OAJI (USA) & $=0.350$ \\
\hline
\end{tabular}

- Преодоление ощущения осознанного и неосознанного отчуждения способности личности в труде и его продуктах с помощью следующих инструментов:

- Достижение симметрии качества труда и вознаграждения.

- Сведение к разумному соотношению различия в размерах вознаграждения управляющих и исполнителей, понятность оснований в подобной пропорциональности.

- Зависимость вознаграждения от динамики повышения квалификации и от участия в совершенствовании производственного процесса.

- Всемерное

задействование социокультурных механизмов стимулирования личности к общекорпоративному движению, вхождению в командные формы движения.

- Устойчивость корпоративной деятельности.

- Сформированность отношений по типу: «Один за всех, все за одного». Активное продвижение командной формы ответственности за результаты труда.

- Организация систематического соревнования по качеству труда.

- Стремление к национальному и международному признанию качества и ассортимента производимых продуктов.

- Формирование трудовых династий, участие в распределении прибыли.

- 4.10. Понимание качества товара как комплексной оценки продукта.

- 4.11. Осознание того факта, что именно «мелочи» раскрывают совершенства качества, поэтому к мелочам нужно относиться как строительному материалу качества.

\section{Заключение}

Во второй половине прошлого столетия наука вступила в новый этап своей непростой истории, получившей название «постнеклассического». Основные перемены происходят, как и прежде, в теории познания и методологии. Классическая наука придерживалась положений аристотелевского толкования логики -

«логической статики», выстроенной на законах тождества и непротиворечивости понятий, согласно формуле «или, или». Если мы имеем некоторое суждение, то в отношении его могут быть высказаны два исключающих друг друга заключения, одно из которых будет истинным, противоположное ему окажется ложным. Всё казалось простым и ясным, как раз такой видел истину ещё Р. Декарт. Неклассическая наука пошла путем диалектической логики, исходящей из развития понятия и конкретности истинного знания. Истинная оценка допускала третью точку зрения - синтетическую. Познание усложнилось. Истинное знание приобрело признаки противоречивости, тезис и антитезис не только отрицали друг друга, а призывали искать способ их сосуществования. Достаточно для наглядности вспомнить историю познания природы света. В абстрактном виде «прерывное» и «непрерывное» - типичные взаимоисключающие противоположности, в конкретном - в качестве физических основ света - они, напротив, взаимообусловливают друг друга, образуя физическую субстанцию светового луча.

Неклассическая наука обязала исследователей не бояться сочетания противоположностей, надо исследовать конкретную форму их взаимности. Диалектическое сочетание противоположностей в отличие от абсолютной противоречивости движения принадлежит не всем противоположностям. Оно относительно. Количество и качество - диалектические категории, их правомерно квалифицировать как своего рода противоположности в характеристике явления. Одно раскрывает сущность, второе - её явления и условия реальности. Но качество и количество противостоят опосредовано через сущность и явление и синтезируются в предмете. Развитие производства определяется тем, как разрешаются отношения этих противоположностей: что нужно предпринять, чтобы увеличение товарной продукции не сказалось на её качестве.

Практическое значение диалектической культуры мышления в совершенствовании управления качеством и ассортиментом производства будет со временем возрастать, так как потребитель вне зависимости от платежеспособности спроса относится к рынку как к той трубе из бассейна, по которой вода утекает. Он готов нести расходы, однако всегда соотносит их со степенью удовлетворённости от вынужденной траты. Ему нужен не товар, а вещь. «Товар» - экономическое понятие, «вещь» - потребительское. Потребителю производственные проблемы малоинтересны. Для производителя же они жизненно важны. Он от них зависит как от источника своего существования и обязан осмысливать производственный процесс по алгоритму, открытому ещё в начальном буддизме: прежде всего надо понять что есть что? Потом выработать решение, что и как делать. После чего найти вербальную форму выражения своего решения - скрытая форма верификации решения. И, наконец, «собрать в кулак» духовно-волевой потенциал, чтобы осуществить план действий. Будда не разработал диалектику управления, он её постиг в образе практического опыта жизни, 


\begin{tabular}{|c|c|c|c|c|c|c|}
\hline \multirow{4}{*}{ Impact Factor: } & ISRA (India) & $=3.117$ & SIS (USA) & $=0.912$ & ICV (Poland) & $=6.630$ \\
\hline & ISI (Dubai, UAE & $=0.829$ & РИНЦ (Russia) & $=0.156$ & PIF (India) & $=1.940$ \\
\hline & GIF (Australia) & $=0.564$ & ESJI (KZ) & $=\mathbf{5 . 0 1 5}$ & IBI (India) & $=4.260$ \\
\hline & JIF & $=1.500$ & SJIF (Morocco) & $=5.667$ & OAJI (USA) & $=0.350$ \\
\hline
\end{tabular}

поэтому его рекомендации относились в основном к жизни, не содержали конкретнопроизводственного опыта и вряд ли имели экономическую ценность для того времени. Сегодня они обретают новую жизнь в качестве именно экономической программы.

Инновационная экономика - это соревнование новаторских инициатив в мышлении. Конкуренция, выражаясь в терминах Гегеля, разумна и действительна как борьба за наиболее плодотворную мысль, способности быть достаточно убедительным в её практическом воплощении - искусным борцом за идею, проект, образец на два фронта: против косности мышления и бюрократизации политики, давно перешедшей все разумные пределы.

Наша либеральная система управления опирается исключительно на себя, создавая впечатление исполнения международных обязательств, сохранения мировых традиций. Международные соглашения соблюдать необходимо, но они заключаются во взаимности интересов, следовательно на них не молиться нужно, а использовать «под себя». Что же до традиций, то они у нас действительно есть, только те, что прошли испытанием временем, оказались почему-то идеологически порочными, их оставили в прошлом. Те же, что сформировались в 1990е и в нулевые, оттолкнули от нас цивилизованную часть мира. Новейшая идеология управления национальным лицом избрала Столыпина. С такой «иконой» нам нечего делать в мире инновационного мышления. Вместо того, чтобы умиляться его фразой: «Вам нужны великие потрясения, а нам - Великая Россия!» лучше бы рассматривали последнюю часть. Петр Аркадьевич величие России отождествлял с абсолютизацией монархии, а вся его управленческая идея заключалась в стремлении расселить крестьянские Центр и Юг России, которые созревали быть детонаторами буржуазно-революционных преобразований. Двор поменял Витте на Столыпина, чтобы попытаться избежать сценария Великой Французской буржуазной революции. Кроме Романовых и двора, Столыпина позитивно воспринимали лишь консервативно настроенные помещики - класс, который никак не назовёшь инновационным.

Итак, наш главный вывод: конкуренция действительно разумна как творческое соревнование, и власть - политический инструмент управления, призвана создать режим наибольшего благоприятствования рынку творчества, в первую очередь научного, инженерного.

Вывод второй: в навязываемом толковании конкуренция - высоко затратный механизм условно инновационной деятельности. Оценивать эффективность конкурентной борьбы следует не по факту приращения производства качественно и количественно, а по соотношению приращения к затратам - реальным (совокупным) и потенциальным (потерям). Разумность конкуренции существует в её научнотехнической форме реальности, экономически она положительно-отрицательное явление, социокультурно - в порядке культурной творческой инициативы явление бесспорно позитивное.

Специфика современной отечественной реальности определяется противоречием политических составляющих - политики сделали все, чтобы заместить социалистическиориентированную идеологию на капиталистическую, и мало того, чтобы в ускоренном темпе пройти переходный период от социалистической экономики к буржуазной. В связи с чем социальная структура оказалась с глубоким разломом. Политики не управляли процессом реформ, они сопровождали их, формируя олигархические интересы. 140 миллионов россиян остались в неразвитом социализме, остальные - олицетворяют олигархический капитализм. Чем богаче олигарх, тем темнее его история. У дворян всё-таки был, пусть и не тотальный, принцип чести. Отечественных буржуа спасает только аморальность капитализма как общественного устройства, абсолютизировавшего борьбу индивида за преимущество своего социального положения, по существу легализовавшего социалдарвинистский перенос борьбы за существование из природы в социум. Команда, каждый член которой стремится доказать всеми доступными средствами своё преимущество и надеющийся что именно ему повезет сказать последнее слово, открыть решение задачи, поставленной команде, нацеленный на собственную карьеру, а не на благо отечества, остаётся биологическим союзом. Конкуренция, господствующая в стае, наследуется такой командой. Вот почему в восточных странах не повторяют западную форму капитализма. У них своя ментальность и отличный взгляд на конкуренцию. Они идут от исторической целостности семьи и национального единства. Патриотизм их примитивный, но понятный всем, как и всё то, что ему противоречит.

Закономерным выглядит тот факт, что японский специалист К. Исикава, автор «круга качества» и «диаграммы Исикавы» был инициатором понимания тотальности управления качеством как совокупности коллективных действий. Если американцы акцентировали внимание на технико-технологическом процессе, то японский специалист в тотальности управления качеством производства видел 


\begin{tabular}{|c|c|c|c|c|c|c|}
\hline \multirow{4}{*}{ Impact Factor: } & ISRA (India) & $=3.117$ & SIS (USA) & $=0.912$ & ICV (Poland) & $=6.630$ \\
\hline & ISI (Dubai, UAE & $=0.829$ & РИНЦ (Russia & $=0.156$ & PIF (India) & $=1.940$ \\
\hline & GIF (Australia) & $=0.564$ & ESJI (KZ) & $=\mathbf{5 . 0 1 5}$ & IBI (India) & $=4.260$ \\
\hline & JIF & $=1.500$ & SJIF (Morocco & $=5.667$ & OAJI (USA) & $=0.350$ \\
\hline
\end{tabular}

«человеческое лицо». Эффективность управления качеством, утверждал он, обусловлена мобилизованностью интереса всех работников. Идея Исикавы была воплощена в управлении фирмой «Тойота». Именно опыт работы на автоконцерне заставил американцев обеспокоиться за своё положение на авторынке. Уже в семидесятые и восьмидесятые годы прошлого столетия весьма продуктивно работала японская «система предложений». В течение 1986 года более 95 процентов сотрудников «Тойоты» лично и в команде активно способствовали приданию качества производства стабильности. В результате в том же году поступило 2,75 млн. предложений по улучшению организации производства и 96 процентов из них были учтены.

Такое вовлечение коллектива в совершенствование деятельности предприятия, исходя из японского опыта, требует соблюдения ряда условий:

- отношение к инициативе работников не должно быть формальным;

- инициаторы должны чувствовать оперативность в отношении к их предложениям, причём счёт идёт не на недели, декады и даже не на дни, речь о часах, - не более 2-х часов;

- необходимы моральное и материальное поощрения за наиболее интересные предложения, на «Тойоте» таких работников награждали специальной медалью и зачисляли в члены «Клуба хороших идей»;

- в авангарде программы была не конкуренция, а солидарный интерес с фирмой, забота о процветании производства, с которым связано будущее работника и отечества.

Только в 1986 году, по данным Б.С. Алёшина с коллегами, японские компании получили почти 41 млн. предложений от своих служащих. В тоже время компании США - всего около 1 млн. Именно в эти годы и сменился взгляд на Японию. Вместо «японского чуда» появилась «японская угроза».

И снова вернёмся к идеи решать проблемы производства не на основе разделения ответственности за качество результата, заложенной в традиционный способ организации производства, в котором хозяин и работник противопоставлены отчуждением в труде личности исполнителя, а путем преодоления отчуждённости. К. Маркс логически вывел необходимость смены формы собственности частной на общественную, но он прекрасно понимал, что такая метаморфоза требует времени. Она представляет собою исторический процесс. Логический ход мыслей никогда не следует отождествлять с историческим процессом. Для К. Маркса, как диалектика, разведение логического и исторического было прописной истиной.

В диалектике важна цель, в ней аккумулируются движение, однако и само движение значимо в качестве цепи звеньев, содержанием которых являются конкретные формы разрешаемых противоречий. Основное противоречие, запустившее процесс, по ходу движения не разрешимо. Здесь суть в другом возможно ослабление напряженности противоречий. Марксизм же принадлежит к явлениям идеологии насильственного характера. Насилие - крайняя и вынужденная форма действий, она оправдана бездействием, обостряющим положение дел. Если есть стремление стороны, ответственной за противоречие, к взаимодействию со стороной, объективно поставленной в состояние неудовлетворённости своим положением, то в определённых пределах возможен не только компромисс, но и сближение векторов движения интересов. Комплементарность участия в производстве - реальное явление в двух случаях: во-первых, когда работник становится акционером и участвует в распределении дохода предпринимателя; во-вторых, тогда, когда его включают непосредственно в процесс совершенствования организации и управления работой предприятия.

Концепцию

«партисипативного

управления» Яндекс позиционирует как нововведение середины XX века. Яндекс стремится выглядеть научным источником, что бесспорно хорошо. Только пока это не всегда реализуется должным образом. Разумеется, Яндекс не отвечает за качество контента, но за селекцию то он должен нести всю полноту ответственности. Открываем авторитетную английскую научную энциклопедию «Britannica» - нет статьи «партисипативное управление» и вообе термина «партисипативность». Напомним, «Britannica» постоянно модернизируется и дополняется новационными знаниями. Обращаемся к шеститомному «Курсу для высшего управленческого аппарата», изданному в США в 1967 году и в сокращенном виде появившемуся в СССР в издательстве «Экономика» в 1971 году - термин «партисипативность» отсутствует. В 2004 году появился учебник Б.С. Алешина и его коллег ведущих специалистов РФ по теории управления «Философские и социальные аспекты качества» (издательство «Логос»). Там также нет искомого термина. Нет его и в Словаре русского языка (Институт русского языка РАН), как нет и в многочисленных словарях иностранных языков. О чём это говорит?

Возникает единственная дилемма: или «партсипативное управление» - фантом, или 


\begin{tabular}{|c|c|c|c|c|c|c|}
\hline \multirow{4}{*}{ Impact Factor: } & ISRA (India) & $=3.117$ & SIS (USA) & $=0.912$ & ICV (Poland) & $=6.630$ \\
\hline & ISI (Dubai, UAE & $=0.829$ & РИНЦ (Russia) & $=0.156$ & PIF (India) & $=1.940$ \\
\hline & GIF (Australia) & $=0.564$ & ESJI (KZ) & $=\mathbf{5 . 0 1 5}$ & IBI (India) & $=4.260$ \\
\hline & JIF & $=1.500$ & SJIF (Morocco) & $=5.667$ & OAJI (USA) & $=0.350$ \\
\hline
\end{tabular}

терминологическая связка «партисипативности» с управлением имеет инновационное значение. Ситуации, подобные нашей, - явление не уникальное. К примеру, транспортной науки не найти ни в одном научном классификаторе, между тем под её развитие дают немалые деньги. Но, приведённый пример характеризует историю науки, а она складывается из латентности этапа становления и открытости последующего развития. Первый существует «де-факто», второй уже «де-юре».

Видимо и в нашей истории есть нечто, весьма схожее с научным генезисом. Понятие начало складываться значительно раньше, чем пришло вербальное оформление его. Существенные признаки рождения «партисипативности» в управлении производством появились в то время, когда пришло осознание тупиковости прежнего маршрута движения буржуазной экономики. Рулить производством как электровозом в одиночку, или в команде, обособленной от производителя, бесперспективно, себе в убыток. Надо делиться полномочиями, делегировать функции управления, вовлекать в управленческую деятельность интересы исполнителей, делать управление тотальной деятельностью работников предприятия. Только так можно вовлечь в производство человеческий капитал в полной мере, активизировать его потенциал - профессиональный и человеческий, и не утратить при том своего господствующего статуса.

В организации производства произошло важное изменение - не коренное, но значимое. Появился перспективный способ движения с участием рядовых работников. Состав с электровозом преобразился в электричку, где движет не только головной вагон, а остальные его «грузят» своим присутствием. Противоречие между управляющими и управляемыми сгладилось, потеряв прежнюю силу. На смену ему пришло противоречие между собственниками и положением в структуре менеджмента. Структура производства приобрела «плавающий» характер.

Акционерный принцип организации отчасти снял антагонизм отчуждения. Капитализм отсрочил наступление революционной ситуации. Протест сменился поиском консенсуса. Консенсус зависит от искусства обманывать. В 2002 году Д. Канеман (Израиль) и В. Смит (США) получили Нобелевскую премию. Один за «лепту в теорию психологии бизнеса», другой за «создание альтернативных механизмов, которые можно применять при решении вопросов либерализации рынка и приватизации государственных монополий».
Современное экономическое и социальное развитие благоприятствует развитию теории и практики партисипативного подхода к управлению производством. В нём имплицировано содержатся основные преимущества нашей цивилизации - гуманизм и демократизм, он способен придать общественному прогрессу устойчивый характер, сделать распределение продуктов производства более справедливым, а в конечном счете сформировать больше позитивности во взглядах на жизнь текущую и обрести некоторую устойчивость в ожиданиях большинства населения.

В возрастающем интересе к партисипативному подходу в управлении производством просматривается стремление определенной части экономистов вернуться к исходным положениям классической политэкономии. Творцы трудовой теории стоимости в экономической науке видели учение о том, как сбалансировать и оптимизировать рост производительности труда и увеличение вознаграждения за это приращение. Они пытались определить условия экономической справедливости, взяв за точку отсчёта производящий труд. Совершенствование производства для них было заточено на справедливости распределения, что позволяло рассчитывать управляющим на взаимопонимание и совместную работу над развитием производства c работниками. До К. Маркса не было ещё понимания неизбежности в буржуазном производстве отчуждения, но опыт философской рефлексии над процессом производства, его организации, направлял мысль предшественников марксизма на анализ проблем в контексте социально-политического формата демократических перемен в обществе. Ориентиром развития экономики для них был человек, а не прибыль. Поход за прибылью законным признавался только под флагом гуманизма - высшей ценности демократической идеологии.

Большинство нынешних экономистов предпочитают не усложнять себе жизнь. Их самих готовят вне предметной специализации, поэтому и взгляд таких экономистов предметно стерилен. Они начинают с разделения, отцепляют всё, что не участвует непосредственно в производстве и далее оценивают экономические проблемы вне всего остального. Это и есть в «чистом» виде метафизическое мышление, обреченное на кризис. Внедрение партисипативности в организации производства один из путей оздоровления экономики за счёт вовлечения в процесс управления энергии основной производящей продукт силы. «Время 


\begin{tabular}{|c|c|c|c|c|c|c|}
\hline \multirow{4}{*}{ Impact Factor: } & ISRA (India) & $=3.117$ & SIS (USA) & $=0.912$ & ICV (Poland) & $=6.630$ \\
\hline & ISI (Dubai, UAE & $=0.829$ & РИНЦ (Russia & $=0.156$ & PIF (India) & $=1.940$ \\
\hline & GIF (Australia) & $=0.564$ & ESJI (KZ) & $=\mathbf{5 . 0 1 5}$ & IBI (India) & $=4.260$ \\
\hline & JIF & $=1.500$ & SJIF (Morocco & $=5.667$ & OAJI (USA) & $=0.350$ \\
\hline
\end{tabular}

разбрасывать камни» проходит. Пора учиться их «собирать».

Партисипативное управление - что это такое Концепция партисипативного управления возникла в середине XX века, вместе с развитием принципов управления персоналом в качестве отдельной специализации. В первую очередь, партисипативное управление - это методы организации труда, когда каждый работник прямо может участвовать в деятельности организации в целом, что позволяет решить сразу несколько важных для хозяйственной деятельности аспектов. Тем не менее, на сегодняшний момент варианты реализации партисипативного управления могут отличаться друг от друга. Наиболее распространенными являются следующие методики организации труда: Участие работников в управлении. В данном случае сотрудники имеют возможность в первую очередь влиять на решения работодателя или высшего руководства в целом. При этом именно участие работников в управлении является наиболее распространенным видом партисипативного подхода к организации труда. Подобные методы позволяют повысить мотивацию и личную заинтересованность сотрудников, a также их психологический комфорт. Участие сотрудников в собственности предприятия. Таковая ситуация предполагает в первую очередь передачу части предприятия в собственность работников при помощи различных механизмов. Это может быть обеспечение сотрудников акциями, предоставление им по прошествии определенного времени средств производства или иной собственности в личное пользование и владение и иные методы воздействия. Такой подход позволяет снизить потери предприятия, так как сотрудники будут прямо заинтересованы в сохранении средств производства и повышении результативности труда. Подобный метод наиболее часто реализуется при помощи специальных бестарифных систем оплаты труда, когда зарплата работников напрямую зависит от того, насколько полезны они были с экономической точки зрения для предприятия. Подобный способ организации труда задействует в первую очередь прямую материальную мотивацию трудящихся. В том или ином виде партисипативное управление применяется практически повсеместно. Институт профсоюзов и действующее российское трудовое законодательство также содержат отдельные нормативы, имеющие черты партисипативного управления. Например - работники обладают определенными правами по формированию специальных комиссий, а многие действия работодателя ограничиваются положениями коллективного договора или требуют обязательного согласования с профсоюзом. Однако в первую очередь под партисипативным управлением подразумевается именно закреплённое в локальных нормативных актах предприятия добровольное предоставление им различных способов воздействия на деятельность предприятия в целом.

Права работников при партисипативном управлении - примеры

Чтобы лучше понять, как именно могут выглядеть элементы партисипативного управления в организации, в первую очередь следует рассмотреть права, которые в рамках подобной системы труда могут обретать работники. Примерами возможных прав сотрудников при партисипативном управлении могут служить следующие ситуации: Право самостоятельного формирования подразделений в рамках организации. В данном случае предполагается возможность нивелировать психологическую несовместимость работников и сопряженные с ней конфликты за счет того, что трудящиеся самостоятельно сформируют коллектив, который будет работать максимально эффективно. Право принятия самостоятельных решений в вопросах выбора трудовой деятельности и времени её осуществления. Реализуется такое право в первую очередь за счет применения гибких графиков, различных тарифных ставок и взаимозаменяемой деятельности сотрудников. Право участия в инновационном менеджменте. Работники, имеющие возможность продвигать и внедрять инновации, могут быть поощрены за свои действия. При этом групповая мотивация участия в подобных проектах может еще сильнее повысить эффективность труда как отдельного подразделения, так и всего предприятия в целом. Право операционного контроля. Если работники имеют возможность контролировать результаты труда иных сотрудников или всего подразделения, а также несут личную ответственность за качество продукции или оказываемых услуг - подобные механизмы тоже могут считаться частью партисипативного управления. При этом помимо ответственности данное право должен подразумевать и определенное вознаграждение при выполнении или перевыполнении требований работодателя. Право группового и личного участия в производственных и организационных вопросах. Проведение различных мозговых штурмов с участием всего коллектива, привлечение сотрудников к обсуждению планируемых изменений в организационном или производственном процессе - это тоже эффективные методы партисипативного управления. Это - лишь краткий перечень возможных прав сотрудников. При этом 


\begin{tabular}{|c|c|c|c|c|c|c|}
\hline \multirow{4}{*}{ Impact Factor: } & ISRA (India) & $=3.117$ & SIS (USA) & $=0.912$ & ICV (Poland) & $=6.630$ \\
\hline & ISI (Dubai, UAE & $=0.829$ & РИНЦ (Russia) & $=0.156$ & PIF (India) & $=1.940$ \\
\hline & GIF (Australia) & $=0.564$ & ESJI (KZ) & $=\mathbf{5 . 0 1 5}$ & IBI (India) & $=4.260$ \\
\hline & JIF & $=1.500$ & SJIF (Morocco) & $=5.667$ & OAJI (USA) & $=0.350$ \\
\hline
\end{tabular}

работодатели могут разрабатывать и свои, индивидуальные системы вовлечения работников в деятельность предприятия, а также комбинировать и использовать любые другие имеющиеся наработки. Также следует помнить, что работодатель не обязан обеспечивать партисипативность управления в рамках всей организации - подобные принципы могут применяться и к ограниченному контингенту работников или присутствовать лишь в рамках отдельных структурных подразделений, где их использование будет наиболее целесообразным.

Преимущества

партисипативного

управления Популяризация партисипативного управления возникла в первую очередь за счёт объективных преимуществ, которые предоставляет подобный способ организации труда. Конечно, непосредственные достоинства данной методики могут отличаться в зависимости от используемых механизмов и особенностей каждого конкретного субъекта хозяйствования, однако ключевые аспекты будут одинаковыми во всех случаях. Так, к преимуществам партисипативного управления можно отнести повышение мотивации персонала. Работники, принимающие прямое участие в непосредственной деятельности предприятия, имеют куда более высокую мотивацию, особенно если от качества и объемов их участия зависит и их непосредственное материальное вознаграждение. Сплочение коллектива. Методы партисипативного участия напрямую демонстрируют сотрудникам важность коллективного и группового подхода к решению основных вопросов, что снижает количество конфликтов и стимулирует коллектив работать вместе над поставленными перед ним задачами. Повышение лояльности работников к предприятию. $\mathrm{B}$ рамках партисипативного управления работник не рассматривается только в виде обезличенного ресурса, равно как и предприятие для таких сотрудников перестает быть исключительно источником дохода, а становится ещё и результатом их прямой деятельности. Соответственно, партисипативное управление повышает лояльность сотрудников к предприятию и обеспечивает достаточное снижение текучести кадров в рамках структурного подразделения или субъекта хозяйствования в целом. Кроме этого, высокая лояльность сотрудников часто может помочь в преодолении кризисных ситуаций. Ускорение развития и внедрения инноваций. За счёт партисипативности в рамках предприятия, повышается вероятность нахождения более эффективных методов производства и организации труда, так как в вопросах поиска и внедрения инноваций участвует большое количество работников, что позволяет находить нестандартные и наиболее актуальные решения для каждого конкретного случая. Улучшение имиджа предприятия. Партисипативное управление и соответствующее партнерское отношение к сотрудникам косвенно влияют и на внешний имидж предприятия в целом, что находит позитивное отражение практически во всех аспектах хозяйственной деятельности, начиная от упрощения поиска кадров и заканчивая повышением фактических продаж. Увеличение эффективности экономической деятельности. За счёт вышеозначенных достоинств и иных факторов, правильное применение партисипативной системы управления предприятием приводит к повышению общей экономической эффективности предприятия в большинстве случаев. Недостатки, которыми характеризуется партисипативное управление Несмотря на большое количество положительных сторон, партисипативное управление имеет и ряд определенных недостатков, что ограничивают распространение подобной бизнес-модели. Так, партисипативное управление характеризуется следующими минусами,а именно,имеет низкую эффективность в отдельных сферах деятельности. Если сфера деятельности субъекта хозяйствования предполагает, в первую очередь, использование низкоквалифицированной рабочей силы или просто монотонный и рутинный труд, без особых перспектив карьерного роста, развития или применения творческого потенциала сотрудников, то партисипативное управление будет демонстрировать отрицательную эффективность. Снижение авторитета руководства. Так как партисипативное управление предусматривает в первую очередь партнёрство, как метод субординации на работе, то в любом случае непосредственный административный авторитет руководства при применении данного способа организации труда будет снижаться. Риски злоупотреблений. Неправильное применение партисипативного управления, а также несоответствие её принципов наличествующему коллективу может привести к злоупотреблениям со стороны работников своими правами в целях простого уменьшения личной нагрузки на себя во время работы. Сложность имплементации. Далеко не всегда сотрудники могут в полной мере осознавать достоинства партисипативной системы управления именно для них, поэтому работодателю следует озаботиться о максимально подробном и длительном механизме донесения информации о преимуществах такой организации труда для сотрудников. Кроме этого, партисипативное управление также должно быть максимально подробно отражено и в кадровой документации предприятия - локальных 


\begin{tabular}{|c|c|c|c|c|c|c|}
\hline \multirow{4}{*}{ Impact Factor: } & ISRA (India) & $=3.117$ & SIS (USA) & $=0.912$ & ICV (Poland) & $=6.630$ \\
\hline & ISI (Dubai, UAE & $=0.829$ & РИНЦ (Russia & $=0.156$ & PIF (India) & $=1.940$ \\
\hline & GIF (Australia) & $=0.564$ & ESJI (KZ) & $=\mathbf{5 . 0 1 5}$ & IBI (India) & $=4.260$ \\
\hline & JIF & $=1.500$ & SJIF (Morocco & $=5.667$ & OAJI (USA) & $=0.350$ \\
\hline
\end{tabular}

нормативных актах, трудовых договорах и иных документах. Большинство недостатков, которыми характеризуется партисипативное управление, могут быть нивелированы при правильном руководстве и подходе к формированию данной системы организации труда. Однако некоторые из них являются структурными и не позволяют применять с должной эффективностью подобную методику в рамках ведения бизнеса. Поэтому, прежде чем приступать к внедрению означенной системы, следует тщательно проанализировать те преимущества и недостатки, которыми она будет обладать в рамках конкретного предприятия и конкретной сферы деятельности.

\section{References:}

1. (2015). GOST R ISO 9000-2015 quality management System. The main provisions and Glossary (Amendment).

2. (2015). GOST R ISO 9001-2015 quality management System. Requirements GOST R ISO 9001-2015 national standard of the Russian Federation quality management system date of introduction 2015-11-01.

3. (n.d.). GOST R 57189-2016 / ISO / TS 9002:2016. National standard of the Russian Federation. Quality management system. Guidance on the application of ISO 9001:2015 (ISO/TS 9002:2016, IDT)" (app. By the order of Rosstandart on 25.10.2016 N 1499-St). [Official website of the International organization for standardization (ISO)] Retrieved January 22, 2019, from http://www.iso.org/iso/ru/catalogue_detail?csnu mber $=52844$

4. (2010). GOST R ISO 9004-2010. Managing for the sustained success of an organization. Quality management approach.

5. Prokhorov, V. T., Tikhonova, N. I., Aspen, T. M., Reva, V. D., Tartans, A. A., \& Kozachenko, P. N. (2014). On the impact of nanomaterials and technologies in injection molding properties of polymer compositions based on ethylene vinyl acetate. Vestnik Kazanskogo tekhnologicheskogo universiteta, Vol. 17, No. 19, 130-135.

6. Prokhorov, V. T., et al. (2015). About new opportunities of regions of SFD and skfo on formation of preferences by consumers of the production made at the enterprises of light industry: the monograph. on the General edition of doctor of technical Sciences, prof. V. T. Prokhorov (Eds.). In the sphere of service and business (Phil.) Fader. state budget. educated. institutions higher. professional education "don state technical. UN-t " in the Mine Growth.region. (Isoip (branch) DGTU). (p.316). Novocherkassk: URGU (NPI).
7. Prokhorov, V. T., et al. (2017). The concept of import substitution of products of light industry: background, challenges, and innovations: monograph under the General editorship of Dr. sci. prof. V. T. Prokhorova (Eds.). Institute of service sector and entrepreneurship (branch) of don state technical University. (p.334). Mines: Isoip (branch) DSTU.

8. Prokhorov, V. T., et al. (2014). The quality revolution: through the ad or through a quality real: monograph under the General editorship of doctor of technical Sciences, Professor V. T. Prokhorov (Eds.). VoIP (branch) of DSTU. (p.384). Novocherkassk: URGU (NPI).

9. (2018). Management of the real quality of products and not advertising through the behavior of the leader of the team of the enterprise of light industry: monograph / Ed. prof. V. T. Prokhorova (Eds.). Institute of service sector and entrepreneurship (branch) of don state technical University. (p.384). Novocherkassk: URGU (NPI).

10. Ricardo, D. (1955). Vol. 3 T. T. I - M.: State. Izd-vo polit. lit-ry, 360.

11. Khazin, M. L. (2016). Economic science and modern political situation . "Questions of new economy" №3 (39), 106-111.

12. (1961). Engels, ATI-During. K. Marx and F. Engels. Op. Ed. watt. Vol. 20. (p.827). M.: State Policy.

13. Aleshin, et al. (2004). Philosophical and social aspects of quality: Uch.posob. (p.438). Moscow: Logos.

14. (2015). Advertising as a tool to promote the philosophy of quality of production of competitive products in the Eurasian space. Edited by V. T. Prokhorov (Eds.). (p.528). Voronezh-Moscow. DSTU publishing house.

15. Scissors, Z. (2000). Mysterious Muscovy. Russia through the eyes of foreigners. (p.605). M.: AST: Astrel.

16. (2010). Large illustrated encyclopedia. In 32 Volumes. T-25. (p.501). Moscow: AST Astrel. 


\begin{tabular}{|c|c|c|c|c|c|c|}
\hline \multirow{4}{*}{ Impact Factor: } & ISRA (India) & $=3.117$ & SIS (USA) & $=0.912$ & ICV (Poland) & $=6.630$ \\
\hline & ISI (Dubai, UAE & $=0.829$ & РИНЦ (Russia) & $=0.156$ & PIF (India) & $=1.940$ \\
\hline & GIF (Australia) & $=0.564$ & ESJI (KZ) & $=5.015$ & IBI (India) & $=4.260$ \\
\hline & JIF & $=1.500$ & SJIF (Morocco) & $=5.667$ & OAJI (USA) & $=0.350$ \\
\hline
\end{tabular}

17. (2010). Large illustrated encyclopedia. In 32 Volumes. T-22. (p.501). Moscow: AST Astrel.

18. (1997). Cobb, the adoption and continuous development of the Japanese philosophy of
Universal quality management. Tr. 40 th Congress of the EOC. (p.385). Berlin.

19. Yanin, I. T. (2000). encyclopedia of wise thoughts. (p.312). Kaliningrad: GIPP "Yantar Skaz". 